\title{
Servidor de Correio Eletrônico Em Ambiente Computacional Distribuído
}

\author{
Roseli Ribeiro
}

Orientador:

Prof. Dr. Marcos José Santana

Dissertaçäo apresentada ao Instituto de Ciências Matemáticas de São Carlos

- USP, como parte dos requisitos para a obtenção do título de Mestre em Ciências da Computação.

USP -São Carlos

1992 
Aos meus pais Rubens e Maria José, e meus irmãos Rubens e Rose. 
No meio do caminho tinha uma pedra tinha uma pedra no meio do caminho tinha uma pedra

no meio do caminho tinha uma pedra.

Nunca me esquecerei desse acontecimento

na vida de minhas retinas tão fatigadas.

Nunca me esquecerei que no meio do caminho

tinha uma pedra

tinha uma pedra no meio do caminho

no meio do caminho tinha uma pedra.

Carlos Drummond de Andrade

E se não posso

Erguer a pedra até o alto

Sem que ela role de volta

Não desespero

Basta-me erguê-la

Basta-me a luta

Para me encher o coração!

Gránnis Kamarinákis 


\section{Agradecimentos}

ao Prof. Marcos José Santana pela orientação;

aos professores Edson. Nivaldi e Onofre pelas sugestões;

às amigas Alicla. Rita e Sandra pelo auxílio nas horas difíceis:

à Ana Paula. ao José Augusto e à Roseli pela amizade e apoio constante;

àqueles que de um modo ou de outro contribuíram para a relizaçào desse trabalho;

a Deus, pois sem ele nada seria possível.

Este trabalho contou com o apoio do CNPq. 


\section{Resumo}

Este trabalho apresenta o desenvolvimento e a implementaçào de um sistema servidor de correio eletrônico que interliga um ambiente computacional distribuido a outros ambientes (nacionais ou internacionais) através de um sistema distribuido SunOS.

A idéia básica de um servidor de correio eletrônico em um sistema computacional distribuído é ter um servidor responsável pelo serviço de correjo eletrônico. Usualmente um servidor de correio eletrônico é dividido em uma interface com o usuário (software que interage com o usuário para auxiliá-lo a compor e organizar suas correspondências) e em um sistema servidor (processo que gerencia entre out ras coisas o endereçamento e a entrega das mensagens).

Durante o desenvolvimento deste sistema servidor de correjo eletrônico, buscou-se privilegiar o tratamento da interface com o cliente, levando-se em consideraçào a diversidade dos possíveis usuários e a utilizaçào deste serviço no âmbito do IC.ISC. Também foram considerados conceitos de Engenharia de Software durante o desenrolvimento e a implementação, para assegurar um produto de software de boa qualidade. 


\begin{abstract}
This work presents the development and implementation of an electronic-mail server interconnecting the distributed computing environment to other computing environments around the world. through a SunOS distributed system.

The basic idea of an electronic-mail server in a distributed computing environment is to have a special server responsible for the management of the eletronic mail service. Usually, the electronic-mail server is split into two modules: the user interface (the software which directly interacts with users, helping then in the composition and organization of messages) and the server (a process that manages the handles the routing and delivering of messages).

During the development of this system special emphasis was given to user-interface aspects, considering the wide variety of user and the potencial utilization of the software on the whole ICMSC computing environment. Software Engineering concepts were adopted during the development and the implementation phasys in order to ensure the production of high quality software.
\end{abstract}




\section{Conteúdo}

1 Introdução 1

1.1 Motivação e objetivo do trabalho ... . . . . . . . . . . . 1

1.2 Importância do serviço de correio eletrônico . . . . . . . . . . . . . . 2

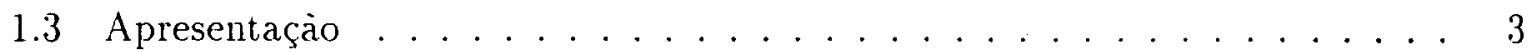

2 Sistemas Computacionais Distribuídos 4

2.1 Introduçào $\ldots \ldots \ldots \ldots \ldots \ldots \ldots$

2.2 Paradigma do cliente/servidor . . . . . . . . . . 7

2.2.1 Chamada de procedimento remoto ...........

2.3 Servidores normalmente presentes . . . . . . . . . . . . . . 10

2.4 Sistema SunOS . . . . . . . . . . . . . . . . . 10

2.5 Redes de computadores . . . . . . . . . . . . . . 11

2.6 Redes locais . . . . . . . . . . . . . . . . . . . 12

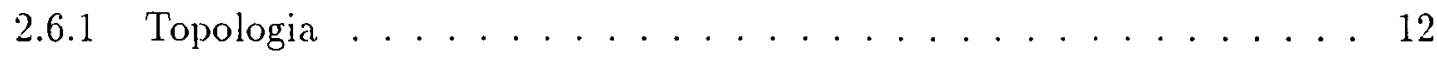

2.6.2 Técnicas de controle de acesso ao meio . . . . . . . . . . . . 14

2.6.3 Um exemplo de rede de comunicação: a rede Ethernet . . . . . . 16

2.7 Consideraçòes finais . . . . . . . . . . . . . . . . 18

3 Protocolos $\quad 19$

3.1 Introduçào . . . . . . . . . . . . . . . . . . . . 19

3.2 Modelo de referência ISO/OSI . . . . . . . . . . . . 20

3.3 Padrão IEEE 802 para redes locais . . . . . . . . . . . . . 23 
$3.4 \mathrm{O}$ conjunto de protocolos TCP/IP . . . . . . . . . . . 24

3.5 Consideraçòes finais . . . . . . . . . . . . . . . . . . 27

4 Correio Eletrônico $\quad 28$

4.1 Introduçào . . . . . . . . . . . . . . . . . . 28

4.2 Centralizado X Distribuído . . . . . . . . . . . . . . 29

4.2 .1 Proposta de Yu . . . . . . . . . . . . . . . . . . 29

4.2 .2 Proposta de Lambert . . . . . . . . . . . . . . . . . . . . 31

4.3 Padronizaçào . . . . . . . . . . . . . . . . . . 32

4.3 .1 Sistema MOTIS . . . . . . . . . . . . . . 32

4.3.2 DNS - Domain Name System . . . . . . . . . . . . . 35

4.3.3 Formato padrão das mensagens texto na Internet . . . . . . . . . 35

4.4 Exemplos de sistemas existentes . . . . . . . . . . . . . . 37

4.4.1 Sistema de correio eletrônico do sistema SunOS . . . . . . . . . 37

4.4.2 Sistema de correio eletrônico do sistema TRICE . . . . . . . . . 38

4.5 Consideraçòes finais . . . . . . . . . . . . . . . . . . . . . 39

5 Ambiente de implementação $\quad 40$

5.1 Introduçào . . . . . . . . . . . . . . . . . . 40

5.2 Ambiente de utilização . . . . . . . . . . . . . . . . 41

5.2 .1 A rede ANSP . . . . . . . . . . . . . . . 44

5.3 Mecanismo de acesso ao meio . . . . . . . . . . . . . . 45

5.4 Especificaçào do mecanismo de RPC . . . . . . . . . . . . 47

5.4 .1 Mecanismo de RPC . . . . . . . . . . . . . . 47

5.5 O uso de alias pelo despachador Sendmail . . . . . . . . . . . . . 51

5.6 Consideraçòes finais . . . . . . . . . . . . . . . . . 52

6 Implementação do sistema $\quad 53$

6.1 Introduçào . . . . . . . . . . . . . . . . . . . . . 53 
6.2 Esquema de alias no sistema SunOS. . . . . . . . . . . . 55

6.3 Ligaçào do sistema SunOS ao ambiente LASD . . . . . . . . . . . . . . . 56

6.4 Desenvolvimento dos softwares servidor e cliente. . . . . . . . . . . 58

6.4.1 "Extensão" do mecanismo de RPC . . . . . . . . . . . . 59

6.4 .2 O soltware servidor ........................ 61

6.4.3 O software das estaçòes clientes . . . . . . . . . . . . 68

6.5 Consideraçoes finais . . . . . . . . . . . . . . . . . . 72

$\begin{array}{llr}7 & \text { Conclusões } & \mathbf{7 4}\end{array}$

7.1 Considerasòes iniciais . . . . . . . . . . . . . . . . 74

7.2 Crítica bibliográfica . . . . . . . . . . . . . . 74

7.3 Contribuiçòes deste trabalho . . . . . . . . . . . . . . . 76

7.4 Conclusòss. . . . . . . . . . . . . . . . 76

7.5 Trabalhos futuros . . . . . . . . . . . . . . . 77

$\begin{array}{ll}\text { A Glossário } & 79\end{array}$

$\begin{array}{ll}\text { B Lista de Siglas } & 81\end{array}$

$\begin{array}{ll}\text { Bibliografia } & 84\end{array}$ 


\section{Lista de Figuras}

2.1 Sistema fracamente acoplado [COUs8] . . . . . . . . . . 5

2.2 Sistema fortemente acoplado [COUss] $\ldots \ldots \ldots \ldots$

2.3 Esquema de uma RPC [BIRs4] . . . . . . . . . . . . 8

2.4 Topologias básicas de redes locais. [CLA78] . . . . . . . . . . . 14

2.5 Pacote Ethernet [METT6, TANS9] . . . . . . . . . . . 17

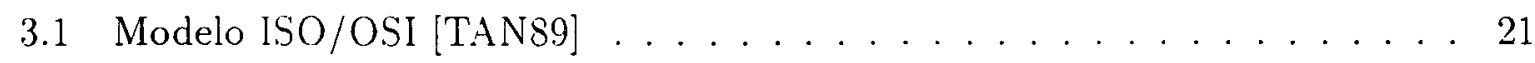

3.2 a) Modelo ISO/OSI e a arquitetura IEEE S02. b) Padrào IEEE S02 [TAR86] 23

3.3 Arquitetura da Internet $[\mathrm{COM} 91] \ldots \ldots \ldots \ldots$

4.1 Esquema da proposta de Yu [YUT9] . . . . . . . . . . . . . 30

4.2 Esquema cla proposta de Lambert [LAM88] . . . . . . . . . . . . . . . 31

4.3 Modelo geral de um sistema de correio eletrônico [TAN89] . . . . . . . 33

4.4 Máquinas requisitadas pelo despachador Sendmail [SU 90$] \ldots$. . . . . . 37

5.1 Ambiente das redes do ICMSC [SAN92] . . . . . . . . . . . . 42

5.2 Ligação do ICMSC ao mundo exterior . . . . . . . . . . . . . . 43

5.3 Sistema servidor de correio eletrônico . . . . . . . . . . . . . . . . 44

5.4 A topologia da rede ANSP em $1992[$ GET92] . . . . . . . . . . . . 45

5.5 Mapas de estados do Packet Driver [TRI91] . . . . . . . . . . . . 46

5.6 Esquema cla semântica "no máximo uma vez" . . . . . . . . . . . . 48

5.7 Pacote PKT $[\mathrm{TRI} 91] \ldots \ldots \ldots \ldots \ldots \ldots$

5.8 Pacote SPP $[\mathrm{TR} 191] \ldots \ldots \ldots \ldots . \ldots \ldots$

5.9 Uso de alias pelo despachador Sendmail [SUN90] . . . . . . . . . . 51 
6.1 Arquitetura do sistema . . . . . . . . . . . . . . . 55

6.2 Estrutura de uma mensagem . . . . . . . . . . . . . 57

6.3 Estrutura do arquivo "entrada" ................ 58

6.4 Restriçào do mecanismo de RPC . . . . . . . . . . . . . . . . . 59

6.5 Relação das primitivas . . . . . . . . . . . . . . . . 60 60

6.6 Estrutura: a) subdiretório MAILBOX: b) dos subdiretórios novo e velho . 62

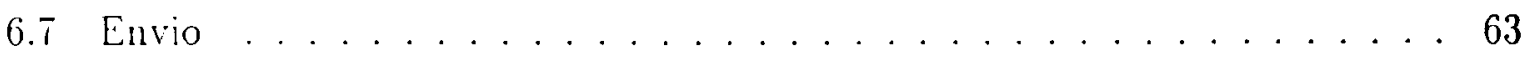

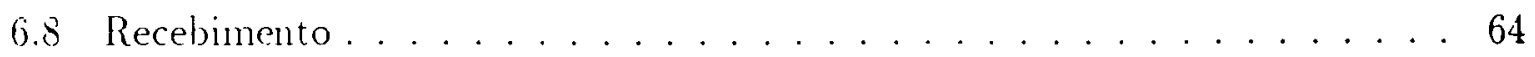

6.9 Estrutura em camadas do software servidor . . . . . . . . . . . 64

6.10 Transaçào entre os protocolos PKT e SPP [TRI91] . . . . . . . . . . 65

6.11 Esquema da execuçào das funçōes da camada RPC . . . . . . . . . . . 6 67

6.12 Estrutura em camadas do software cliente . . . . . . . . . . 68

6.13 Tela de apresentação . . . . . . . . . . . . . . . . 70

6.14 Linha de cabeçalho . . . . . . . . . . . . . . . . 70

6.15 Tela para gerenciar o sistema ... . . . . . . . . . 71 


\section{Lista de Tabelas}

2.1 Redes de computadores . . . . . . . . . . . . . . . . . . . . 12

4.1 Série de recomendaçòes $X 400 \ldots \ldots \ldots \ldots$. . . . . . . . . . . 34

4.2 Campos do "cabeçalho padrào" [TANs9] . . . . . . . . . . . 36 


\section{Capítulo 1}

\section{Introdução}

\subsection{Motivação e objetivo do trabalho}

Os sistemas computacionais distribuídos sào normalmente constituidos de vários computadores (ou processadores) compartilhando dados e recursos através de uma rede de computadores [COUSS, TAN85]. Vários serviços fornecidos pelo sistema operacional em sistemas centralizados sào implementados em sistemas distribuídos através de servidores remotos, disponíveis a todo o sistema. Isto implica em uma redução do núcleo do sistema operacional de cada máquina, com menor complexidade e maior confiabilidade. Além disso, a introduçào de novos serviços no sistema é facilitada. A evolução dos sistemas computacionais distribuídos tem sido motivada principalmente pela possibilidade de compartilhar experiências. recursos especializados e informaçōes. entre uma comunidade de usuários relativamente grande [COUS8, TAN85].

O compartilhamento de recursos e informaçōes aumenta a conectividade e permite a introdução de um serviço importante: o correio eletrônico, que fornece um método rápido, eficiente e conveniente para troca de informação. A idéia central do serviço de correio eletrônico é permitir que os usuários de vários sistemas de computação se comuniquem uns com os outros utilizando uma rede de computadores como suporte para transmissão e recepção de mensagens. Basicamente, um sistema de correio eletrônico associa a cada usuário do sistema o endereço de uma caixa postal (um arquivo, ou parte de um arquivo), onde são depositadas as mensagens que chegam para ele ou que ele envia [QUA86].

A idéia de um servidor de correio eletrônico em um sistema distribuído consiste em ter um servidor (centralizado ou distribuido) responsável pelo serviço de correio eletrônico. $\mathrm{O}$ modelo, nesse caso, estabelece a utilização de uma interface com o usuário (executando no sistema do usuário) e um sistema servidor. A interface com o usuário corresponde a um software que interage com o usuário, ajudando-o a compor e a organizar suas correspondências. O sistema servidor é um processo responsável por gerenciar o endereçamento, entregar, armazenar, transmitir e retransmitir as mensagens dos usuários [HIL88].

A utilizaçăo do serviço de correio eletrônico, em particular em um sistema computacional distribuído, apresenta alguns aspectos interessantes. No começo, existem poucas 
pessoas interessadas e o fluxo das mensagens é baixo. Em um curto espaço de tempo, o número de pessoas interessadas cresce e o fluxo aumenta consideravelmente. Este foi o caso do ICMISC. onde o serviço de correio eletrònico era inicialmente fornecido por um computador. interconectado através de linhas telefônicas a um sistema remoto. O serviço de correio eletrônico foi melhorado com o acréscimo do serviço de correio eletrônico do sistema distribuido SunOS (ou simplesmente sistema SunOS) que possibilita o acesso a diversas redes nacionais e internacionais. Entretanto, o sistema distribuído SunOS do IC:MSC possue poucas estações, que são utilizadas para o clesenvolvimento de diversos projetos, dificultando assim o acesso ao serviço de correio eletrônico.

Este trabalho foi implementado como um servidor de correio eletrônico para efetuar a ligaçào entre o ambiente computacional distribuído do Laboratório de Sistemas Digitais (ou simplesmente ambiente LASD) a outras redes (nacionais e/ou internacionais), através de um sistema SunOS. Este servidor possibilita que un número maior de usuários do ICMSC tenha acesso a um serviço cada vez mais procuracio, o correio eletrônico. Posteriormente, a utilizaçào deste serviço poderá ser estendida a outras redes locais que compóem as redes departamentais clo ICMSC (figura 5.1)

\subsection{Importância do serviço de correio eletrônico}

No último século, as linhas ferroviárias revolucionaram o mundo fornecendo uma rede de transporte para cargas em geral. As redes de computadores iniciaram uma nova revolução fornecendo a tecnologia para transporte de dados, para uma sociedade na qual a troca de informaçào tornou-se essencial. Teve início uma nova visào do mundo, diminuindo distâncias geográficas e formando novas comunidades de pessoas que trocam informações freqüentemente [COM91].

Um dos serviços em redes de computadores mais utilizados para efetuar trocas de informações é o serviço de correio eletrônico. Muitos usuários de redes de computadores têm seus primeiros contatos com redes (e até mesmo com computadores) quando utilizam o serviço de correio eletrônico.

O serviço de correio eletrônico funciona para a comunidade científica como uma ferramenta para questionar um colega, por exemplo, a fim de obter ajuda, estabelecer visitas, marcar reuniões e solicitar informações. Além clessas atividades, ele é utilizado para funções mais específicas da comunidade científica, tais como, reagir a artigos, esclarecer pontos com estudantes e colegas, enviar relatórios e artigos para julgamento.

A comunidade científica possue outras ferramentas para efetuar troca de informações, como conversa pessoal, telefone, FAX, sistemas de memorandos e cartas, entretanto, o serviço de correio eletrônico apresenta algumas vantagens. O serviço de correio eletrônico é rápido, tanto em relação ao tempo de preparação quanto ao tempo de transmissão da mensagem. Ao contrário do serviço telefônico, o interlocutor não precisa estar presente, a mensagem é armazenada em sua caixa postal para leitura posterior. $\mathrm{O}$ armazenamento da mensagem em uma caixa postal permite que somente o usuário e pessoas autorizadas possam ter acesso, evitando que a mensagem seja lida por pessoas não autorizadas. Além 
disso. permite ao usuário responder as mensagens conforme for lendo. arquivá-las de acordo com categorias que tenha estabelecido. participar de grupos de interesse e/ou preparar uma resposta-padrào para ser entregue aos rcmetentes de todas as mensagens que chegarem.

\subsection{Apresentação}

O trabalho està dividido em sete capitulos.

Este capítulo apresenta a motivaçào do trabalho e a importância do serviço de correio eletrônico.

O capítulo 2 apresenta alguns tópicos relacionados com o desenvolvimento do trabalho. É feita una revisào bibliográfica de sistemas computacionais distribuidos.

O capítulo 3 apresenta os conceitos básicos dos protocolos de comunicação. É apresentado o modelo de referência ISO/OSI. que é um padrão internacional para interconexão de redes; em seguida é realizada uma abordagem do padrào IEEE $\$ 02$ para redes locais e do conjunto de protocolos TCP/IP utilizado na Internet.

O capítulo 4 trata dos elementos básicos e das principais propostas para um sistema de correio eletrônico. Sào analisados os aspectos para a padronização de sistemas e as tentativas para descentralizaçào de nomes e endereços da Internet. O capitulo é concluido com alguns exemplos de sistemas de correio eletrônico.

O capítulo 5 apresenta alguns pontos relacionados à implementaçào do sistema, ou seja, o ambiente de utilizaçào e as ferramentas disponiveis para a implementação do sistema.

O capítulo 6 apresenta a implementaçăo do sistema no ambiente LASD e no sistema distribuido SunOS.

No capítulo $i$ sào apresentadas as conclusões e sujestões para trabalhos futuros, com o objetivo de complementar e melhorar o sistema desenvolvido. 


\section{Capítulo 2}

\section{Sistemas Computacionais Distribuídos}

Este capitulo aborda tópicos relacionados a sistemas computacionais distribuidos e está organizado em cinco seçòes principais, abrangendo:

- Paradigma cliente/servidor;

- Servidores normalmente presentes;

- Sistema SunOS;

- Redes de computadores;

- Redes locais.

\subsection{Introdução}

Existem várias definições para sistemas distribuídos. Segundo Mullender, em [MUL89], um sistema distribuído é um sistema com vários elementos de processamento e vários dispositivos de armazenamento, conectados através de uma rede de computadores. Assim, um sistema distribuido parece ser um sistema centralizado, mas executa em CPU's múltiplas e independentes. Nesse caso, o conceito básico é a transparência, ou seja, o uso de múltiplos computadores não deve ser visivel para o usuário [COU88, TAN85].

Essa definiçào torna-se necessária mas não suficiente, pois uma variedade de sistemas seriam considerados sistemas distribuídos. Uma outra condição acrescentada por Mullender, em [MULS9], é a tolerância a falhas, ou seja, quando um elemento do sistema falha, algum outro elemento é capaz de assumir o seu trabalho. Duas classes principais de sistemas distribuídos podem ser consideradas [COU88, BAL89]: 
- Sistemas frracamente acoplados: compostos de computadores autônomos interconectados por una rede. cada um executando parte de um sistema operacional global e compartilhando recursos e informações através da rede (figura 2.1);

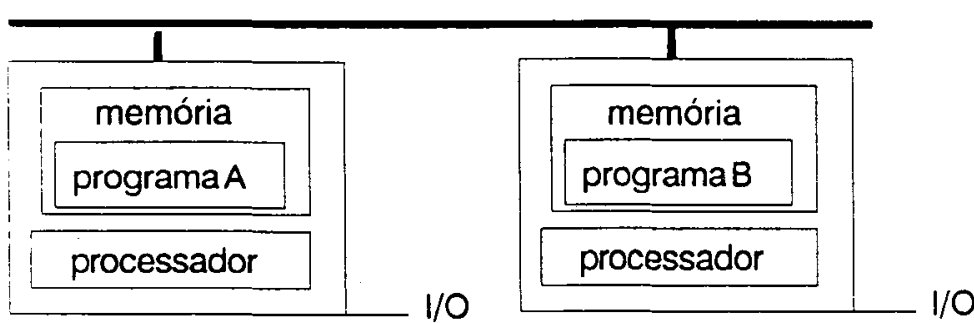

Figura 2.1: Sistema fracamente acoplado [COUs8].

- Sistemas fortemente acoplados: compostos de múltiplos processadores dentro de um sistema de hardware integrado. sob o controle de um único sistema operacional (figura 2.2).

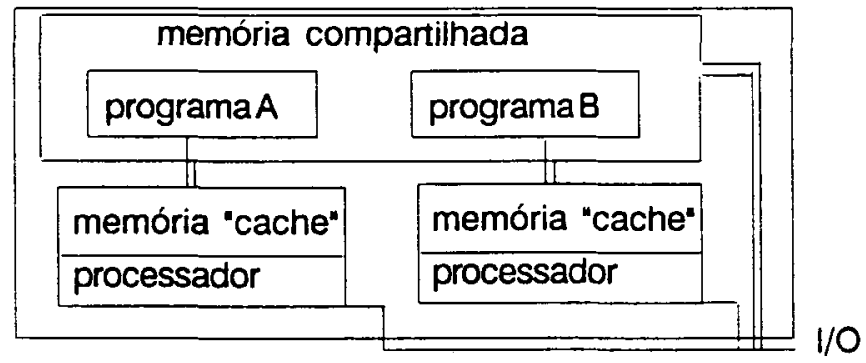

Figura 2.2: Sistema fortemente acoplado [COUS8].

Dependendo do tipo de implementação adotada para o sistema distribuído, diversas vantagens são observadas, podendo-se citar [COU88, MUL89, SAN89, TAN85]:

- extensibilidade: novos recursos podem ser adicionados gradativamente sem interferir com os recursos já existentes no sistema. O fator que limita o crescimento do sistema é a capacidade de comunicação da rede;

- replicação: diversas cópias de um arquivo podem ser armazenadas em locais distintos, aumentando potencialmente a confiabilidade e o desempenho do sistema;

- -disponibilidade: se um elemento falhar, algum outro elemento do sistema pode ser utilizado, evitando a interrupção de todos os processos sendo executados;

- compartilhamento de recursos e informações: recursos caros e informações podem ser compartilhados por um número grande de usuários dispersos pelo sistema;

- mobilidade do usuário: os usuários podem ter acesso ao sistema a partir de diversos pontos distintos; 
- flexibilidadt: diversos recursos estào disponiveis aos usuários, que podem escolher o mais apropriado às necessidades de aplicaçòes particulares.

Apesar das rantagens. observam-se também algumas desrantagens. como [COU88, MULS9, SANS9, SIN91. TAN85]:

- perda de controle: o gerenciamento de recursos e informaçòes torna-se mais difícil, pois pode-se ter acesso aos mesmos de diversos pontos. o que gera problemas de integridacle. privacidade e segurança dos dados:

- dependéncia do sistema de comunicação: a confiabilidade e o desempenho do sistema ficam dependentes da rede: se ela falhar, vários usuários podem ser afetados;

- consisténcia dos dados: se os dados estiverem replicados em vários pontos do sistema. é necessário um esquema eficiente de atualizaçào para mantê-los consistentes.

Os requisitos mais importantes para um sistema distribuido sào transparência, confiabilidade e desempenho elevado. A transparência é importante. pois um dos objetivos de um sistema distribuido é promover um compartilhamento de recursos e informações com a distribuiçào da capacidade. mantendo a distribuiçào oculta ao usuário. Dependendo das características desejadas e dos objetivos do sistema, diversos elementos e organizações podem ser adotados para o sistema. Vários modelos foram sugeridos. podendo agrupá-los nas seguintes categorias [COUS8, TANS5]:

- Estação de trabalho/servidor. onde cada usuário tem acesso a uma estação de trabalho. Programas de aplicaçào sào executados nas estaçǒes de trabalho do usuário, podendo compartilhar arquivos e recursos. Alguns serviços específicos são fornecidos através de servidores:

- Banco de processadores, onde alguns processadores estào disponiveis em um (ou vários) banco(s) de processadores ligados à rede. Quando o usuário, trabalhando em um terminal conectado à rede, precisa de mais capacidade, um ou mais processadores são alocados para ele. Os processadores são liberados e retornam ao banco, quando o trabalho é completado;

- Minicomputador, onde alguns minicomputadores, suportando ambiente multiusuário, são interligados e o usuário trabalha em uma máquina e tem acesso remoto às outras:

- Integrado, onde cada computador do sistema tem um alto grau de autonomia, podendo compartilhar dados utilizando um esquema global de nomes. Os computadores podem ser estações de trabalho ou sistemas multiusuário, mas cada um executa um conjunto completo de software padrão e lida com suas próprias aplicações e serviços, permitindo realizar ambas as tarefas de servidor e processador de aplicação;

- Hibrido, tem-se uma combinação dos modelos banco de processadores e estação de trabalho/servidor. Aplicações gráficas ou com muita interação com o usuário executam em estações de trabalho, enquanto o banco de processadores é utilizado para executar tarefas que exigem mais de um processador. 
Vários sistemas utilizam o modelo estação de trabalho/servidor, alguns deles são: Sprite [LEV90. SANS9] e Trice [SAN89]. O modelo banco de processadores foi adotado pelo sistema Cambridge Ring [COUS8, TAN85], que suporta também máquinas sem disco. I $\mathrm{m}$ exemplo do modelo minicomputador é o sistema Vax cluster [COU88, SAN89, TA:85]. Os sistemas Apollo [COUS8, SAN89, SVOS4]. Newcastle Connection [COUS8. LEV90. SA.V89], Locus [COU88, KIR88, LEV90. SAN89. SVO84], SunOS [COU88, SA 189]. Pulse [SAN89, TOM85] e Keele [SAN89] são exemplos de sistemas integrado. O sistema Amoeba [COUS8, KIR88, TAN85, TAN90], apresenta-se como um exemplo do sistema híbrido.

Um dos modelos mais utilizados é o modelo estaçào de trabalho/servidor, que apresenta um bom desempenho. Esse modelo apresenta uma crescente utilização devido ao aumento da disponibilidade de estações de trabalho com alta capacidade, a um custo relativamente baixo. e pela necessidade de compartilhamento de recursos caros e informaçóes. O modelo banco de processadores é flexivel e bastante utilizado para aplicações com muito processamento e poucas operaçōes de entrada e saída, mas diminue o desempenho, pois exige uma interaçào com o usuário via rede. O modelo híbrido oferece as facilidades do modelo estaçào de trabalho/servidor e a flexibilidade do modelo banco de processadores.

\subsection{Paradigma do cliente/servidor}

A comunicaçào entre processos em sistemas distribuídos geralmente é feita através de passagem de mensagem. Uma forma de se construirem sistemas com passagem de mensagem é através da utilização do paradigma cliente/servidor, no qual um cliente necessitando de algum serviço envia uma mensagem de pedido ao servidor e aguarda uma mensagem de resposta [BIRS4, BIR85]. Comer, em [COM91], define servidor como qualquer software que ofereça um serviço através da rede. Um software torna-se cliente quando ele envia uma mensagem de pedido ao servidor.

A comunicação entre processos pode ser bloqueante (o processo cliente fica bloqueado até o servidor poder receber o pedido) ou não bloqueante (o pedido enviado pelo processo cliente é armazenado em um "buffer", permitindo retransmissão em caso de falha) [COU88, TAN85]. Um modelo simples de implementação, que libera o cliente para efetuar outra atividade após o envio da mensagem, é o mecanismo IPC (InterProcess Communication). Um caso especial de IPC que bloqueia o processo origem até o recebimento de uma resposta, liberando-o em seguida, é o mecanismo de chamada de procedimento remoto ou RPC (Remote Procedure Call).

\subsubsection{Chamada de procedimento remoto}

Uma RPC é uma chamada a um procedimento executado por outro processo e normalmente em um computador diferente, que é requisitada pelo cliente a fim de obter algum serviço executado pelo servidor [COU88]. Schroeder, em [SCH89], garante que com o mecanismo de RPC os programadores de aplicações distribuidas deixam de se preocupar 
com detalhes de enerenciamento c de comunicaçào. pois tudo ocorre como numa chamada de procedimento local. mas com semânticas diferentes.

Segundo Tintenbanmi om [T.L.V5]. uma chamada de procedimento remoto é mais abrangente fur uma simples troca de mensagem. implicando na passagem de parâmetros e dados que levem ser ordenados. A ordenaçào dos parâmetros e dados é chamada de "marshalling." I passigem de paràmetros por valor em uma RPC' é imediata, os valores sào apenas copiados na mensagem a ser enviada. entretanto, às vezes nào é possivel efetuar a passagen de parametros por referência. pois os processos podem estar sendo executados em espaços de memoria disjuntos [COUS8. TANS9. WIL87].

Uma possirel estrutura para RPC é apresentada por Birrell. em [BIR84], contendo as seguintes camarlas na máquina cliente e na máquina servidor (figura 2.3):

- a camada de interface - fornece a transparência entre os procedimentos remotos e locais. ('onsiste de uma lista de definiçòes dos procedimentos. seus parâmetros com os respectivos tipos de dados e os possiveis resultados:

- a camada "s $b b^{\prime}$ - é uma camada de software que contém os procedimentos que sào exccutados quando uma chamada de procedimento remoto é solicitada. Ela é responsável por preparar os dados e parâmetros em uma ou mais mensagens para a transmissào. A camada "stub" no servidor também precisa identificar o processo para o qual a mensagem deve ser enviada;

- a camada de RPC - é uma camada de software responsável pela comunicação a nível de pacote. com o objetivo de montar pacotes a serem transmitidos e receber pacotes. Para montar um pacote, ela recebe os dados da camada "stub", acrescenta um cabeçalho de controle e encaminha o pacote para a transmissào. O cabeçalho de controle deve conter entre outras coisas os endereços origem e destino, e o tipo do pacote. to receber um pacote, ela verifica e retira o cabeçalho de controle, enviando somente os dados à camada "stub".

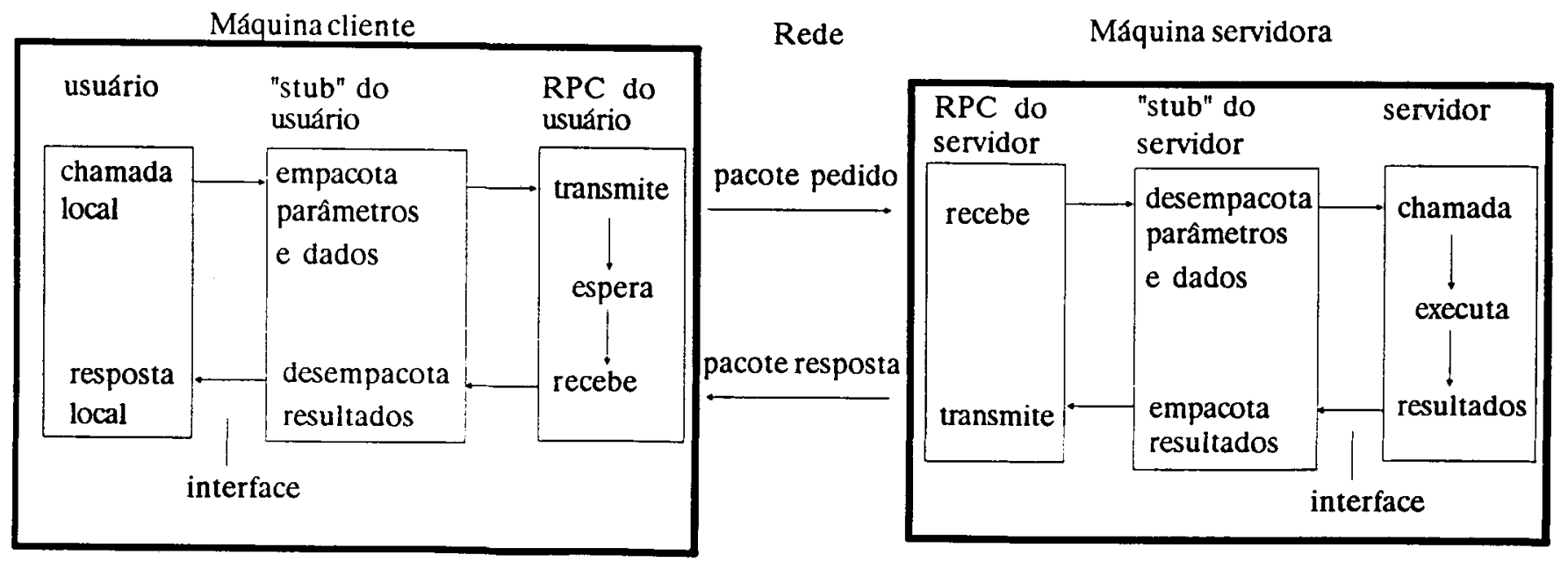

Figura 2.3: Esquema de uma RPC [BIR84]. 
Quando um cliente faz um pedido e recebe uma resposta. diz-se que a RPC foi executada com sucesso. Contudo. o sucesso em uma RPC nào é garantido, pois podem ocorrer perda de mensagens, falhas do cliente ou do servidor. ou ainda falhas no meio de comunicaçăo. lesses casos. o cliente deve ser capaz de retransmitir o pedido e o servidor deve prover algum mecanismo de deteç̧ào de pedidos duplicados. Outro problema decorrente de fallias é o bloqueio de clientes esperando indefinidamente uma resposta, normalmente para resolver esse problema é utilizado o mecanismo de "time out" [BIR84, BIR85, COL85]. Para a detecção de falhas pode-se utilizar algumas semânticas, que determinam a freqüiência que um pedido deve ser executado. Pode-se citar as seguintes semânticas [COLS8. LIS90, SHRS2, TAN89, WILST]:

- possivelmente recebida: é assumido que o pedido será executado. Não muito utilizada. pois exige alta taxa de confiabilidade da rede. Para certas operações não se pode confiar apenas na rede;

- pelo menos uma $v e z:$ o pedido é repetido até que uma mensagem de resposta seja recebida. Exige que as operações sejam "idempotents", isto é, as execuções repetidas sejam equivalentes a uma única;

- no máximo uma vez: o servidor controla os pedidos dos clientes, de tal forma que um pedido nào seja executado mais que uma vez. Bem aceitável, pois um pedido repetido. motivado pela perda da resposta, ocasiona a retransmissão da última resposta calculada para a operaçào solicitada;

- exatamente uma vez: é a semântica mais forte, pois as ações no servidor devem ser atômicas. garantindo a execução das operações uma única vez. Hả a necessidade de ter informações armazenadas para contornar falhas no hardware.

As implementações de RPC podem utilizar duas, três ou quatro mensagens, como segue [SAN89. TAN85]:

- $R P C$ com duas mensagens: a mensagem de resposta é utilizada como reconhecimento para a mensagem de pedido e o próximo pedido atua como reconhecimento da mensagem de resposta anterior;

- $R P C$ com três mensagens: a mensagem de resposta atua como reconhecimento das mensagens de pedido e somente mensagens de respostas têm reconhecimento explícito;

- $R P C$ com quatro mensagens: cada mensagem de pedido e resposta é reconhecida separadamente.

A utilização de duas mensagens na implementação de RPC é mais conveniente, desde que utiliza um número mínimo de mensagens, contudo, requer uma implementação mais complexa para assegurar a confiabilidade. 


\subsection{Servidores normalmente presentes}

A utilizaçio de servidores para executar serviços especificos reduz o núcleo do sistema operacional e simplifica a adiçào. a modificaçào e teste de novos serviços [TAN85]. Diferentes tipos de servidores podem ser implementados [COU88. HIL88. SAN89, TAN85, TRI91]:

- Servidor de correio eletrônico: fornece o serviço de correio eletrônico aos usuários do sistema. utilizando a rede como meio de transmissào das mensagens;

- Servidor de impressaio: oferece o serviço de impressào aos usuários do sistema. Esse serviço pode ser implementado utilizando pré-alocaçào da impressora (a impressora é alocada para um usuário por vez) ou "spooling" (arquivos para impressão são enfileirados em um "buffer" local no servidor);

- Servidor de processamento paralelo: fornece o serviço de processamento paralelo, ou seja. a realizaçăo de diversas atividades computacionais simultaneamente no tempo;

- Servidor de arquivos: oferece um sistema de armazenamento de informaçòes confiável, que possa ser compartilhado pelos usuários conectados à rede;

- Servidor de nomes: implementa um esquema de nomes e endereços. Tem como funçào principal traduzir identificadores (normalmente caracteres ASCII) para endereços ou códigos, de acordo com a funçăo desejada.

Os servidores completam o ambiente de aplicação, fornecendo serviços a todos os usuários do sistema. O servidor de correio eletrônico é bastante utilizado pois, possibilita além da troca de mensagens, um meio confiável para a transmissào de arquivos.

\subsection{Sistema SunOS}

O sistema SunOS (desenvolvido pela SUN Microsystems, U.S.A.) é um sistema operacional de rede construido como uma extensão do sistema operacional UNIX, fornecendo um sistema de arquivos distribuído. O sistema utiliza o conjunto de protocolos TCP/IP (Transmission Control Protocol/Internet Protocol), o qual fornece alguns protocolos de aplicação, tais como, o TELNET, o FTP e o SMTP [SUN90, SUN91a, TAN85]. O sistema é baseado no modelo integrado, com estações de trabalho (estações SUN), um sistema multiusuário e uma rede local seguindo o paradigma cliente/servidor, esses recursos são gerenciados pelo sistema operacional 4.2 BSD UNIX.

O NIS (Network Information Service) é um servidor de nome (servidor de páginas amarelas), que fornece serviço de nomeação ao sistema SunOS. É um mecanismo para identificar e localizar objetos e recursos acessíveis aos usuários. As bases de dados do NIS, também conhecidas como mapas, são distribuídas entre várias máquinas e são atualizadas a partir de uma base de dados central de maneira automática e confiável, assegurando 
assim que os clicutes compartilhem as mesmas bases de dados de uma maneira consistente através da rede [BAL90. COUS8. SUN90].

O NFS (Network File System) do sistema SunOS vê um conjunto de estações de trabalho interconcctadas como um conjunto de máquinas independentes com sistemas de arquivos independentes. Nào há um sistema de arquivos global compartilhado. Está disponivel unu méanismo de proteçào contra acesso nào autorizado. Para que um diretório remoto scja compartilhado de maneira transparente pelo cliente de uma máquina, o usuário dessia máquina deve executar primeiro uma operaçào de montagem. O NFS é implementado dividindo-se o sistema operacional em três camadas: a camada superior trata diretórios. mapeando cada caminho num "vnode" (consiste do nome da máquina e do identificador do arquivo). Os "vnodes" são processados pela camada do meio, verificando se sào lucais ou remotos. Se o "rnode" é local. tem-se acesso ao disco local; se ele é remoto. a camada inferior realiza um acesso remoto [BAL89. LEV90. SAN89].

\subsection{Redes de computadores}

As redes de computadores atualmente estão presentes em diversos ambientes, como indústrias, centros de pesquisas, centros governamentais e militares. Na evoluçăo das redes de computadores identificam-se três estágios. O primeiro estágio, antes de 1960, com o desenvolvimento de teorias e idéias relacionadas a transmissão da informação. No segundo estágio, a partir da metade da década de 60 , várias tecnologias foram desenvolvidas para a troca de informaçǒes. redes locais e análises de desempenho de redes. No terceiro estágio, aproximadamente da metade dos anos 70 até os dias atuais, as pesquisas têm se concentrado em fornecer serviços de comunicaçào entre redes interconectadas. Alguns dos resultados do terceiro estágio incluem o desenvolvimento da tecnologia para interconexão de redes e modelos de padronizaçào de protocolos [COM91]. Uma rede de computadores apresenta três componentes principais [LAN86]:

- alguns computadores, que fornecem serviços aos usuários;

- uma rede de comunicação, que consiste de processadores de comunicação de propósito especial:

- um conjunto de protocolos para efetuar a comunicação.

As redes de computadores podem ser consideradas sistemas distribuídos pela definição apresentada por Mullender, contudo Tanenbaum, em [TAN85], faz uma distinçăo adicional, considerando o software básico do sistema sob o ponto de vista do usuário. Desta forma, uma rede de computadores é considerada um sistema distribuído se esse software ocultar do usuário a existência de múltiplos processadores, isto é, o usuário utiliza o sistema como se utilizasse um único computador. Segundo Tanenbaum, em [TAN89], os objetivos básicos de uma rede de computadores são:

- compartilhamento de recursos; 
- confiabilidade promorida pela multiplicidade de recursos:

- modularidade. ou seja. o aumento gradual na capacidade do sistema. O acréscimo de um computador aumenta a capacidade computacional cla rede. o que nào ocorre com o acréscimo de um terminal a uma sistema multiusuário:

- meio de comunicaçào entre usuários geograficamente separados.

As redes de computadores podem ser classificadas quanto à dimensào da área coberta. A tabela 2.1 apresenta um sumário dessa classificaçào [COM91].

\begin{tabular}{||c|c||}
\hline \hline $\begin{array}{c}\text { LAN } \\
\text { (Local Area Network) }\end{array}$ & $\begin{array}{c}\text { cobrem distâncias que variam entre dezenas de } \\
\text { metros a alguns quilometros. }\end{array}$ \\
\hline MAN & utilizam a tecnologia das LANs. cobrindo \\
(Metropolitan Area Netowrk) & a extensào de uma cidade. \\
\hline WAN & $\begin{array}{c}\text { cobrem distâncias que rariam entre dezenas } \\
\text { de quilômetros a milhares de quilômetros. }\end{array}$ \\
\hline \hline
\end{tabular}

Tabela 2.1: Redes de computadores.

A interconexào de redes de computadores forma uma "internet", ou seja, uma interrede. Um dos objetivos de se proporcionar tais ambientes é aumentar a produtividade e a confiabilidade. diminuindo assim os custos [TAN89].

\subsection{Redes locais}

Uma rede local é uma rede de comunicação que interconecta vários dispositivos de comunicaçào de dados em uma área pequena. por exemplo restrita a um único prédio. As principais alternativas tecnológicas que determinam a natureza de uma rede local são sua topologia, o meio de transmissão e a técnica de controle de acesso ao meio utilizada. Essas alternativas definem o tipo de dado que pode ser transmitido, a velocidade e a eficiência da comunicação e os tipos de aplicações que a rede pode suportar [STA84a].

Uma rede local é composta basicamente de três elementos de hardware: um meio de transmissão (par trançado, cabo coaxial ou fibra óptica), uma técnica de controle de acesso ao meio e uma interface entre a rede e os dispositivos conectados a ela. Em termos de software, é necessário um protocolo de comunicação para controlar a transmissão de informação entre dois dispositivos [CLA78].

\subsubsection{Topologia}

Segundo [CLA7S], uma topologia define o padrão de interconexão entre as várias estações da rede. Existe basicamente dois tipos de interconexão, para a comunicação entre as estações [TAN89]: 
- ponto-(1-ponto: as estaçòes da rede estào conectadas a interfaces. interligadas aos pares por moros lísicos de transmissào de dados. I'm campo de endereço especifica a estaçio destino. A interface que recebe uma mensagem nào destinada a estação correspondente a retransmite:

- canal de difunio: neste caso o meio de comunicaçào é compartilhado por todas as interfacés las estaçòes. havendo necessidade de uma técnica de controle de acesso ao meio fue discipline a utilizaçào do canal. Im campo de endereço especifica a estaçào destino. entretanto. mensagens enviadas por uma estaçào podem ser recebidas por todas. I interface que recebe uma mensagem nào destinada a estação correspondente. simplesmente a ignora.

Pode-se irintificar très topologias básicas para redes locais: estrela. anel e barramento.

Topologia em estrela [CLATS. GIOS6. STAS4a].

Na topologia cm estrela. tem-se um elemento central chaveador conectando todas as estaçòes da rerle (figura 2. ta), apresentando assim uma interconexào ponto-a-ponto. Uma estação querendo transmitir envia um pedido ao elemento central que usa comutação por circuito para estabelecer um caminho dedicado entre as estaçòes origem e destino, possibilitando o fluxo da comunicação. Todas as decisões de roteamento estão concentradas no elemento central. simplificando bastante as estaçòes.

Topologia em Anel [CLA78, COM91, GIO86, STA84a. TAN89].

A topologia em anel consiste de interconexǒes ponto-a-ponto entre as interfaces das estações conectadas a rede. formando um laço fechado (figura 2.4b). Uma estação querendo transmitir espera sua vez e envia os dados na forma de pacotes que circulam pelo anel. Os pacotes contêm os endereços das estações destino e origem, seguidos dos dados. Um pacote circulando é analisado por cada interface. que deve copiar os dados se forem endereçados à estaçào correspondente. Usualmente a mensagem copiada continua circulando no laço até voltar a interface origem, que a retira de circulaçào.

Um dos pontos negativos nessa topologia é que, a quebra no anel ou na interface pode parar a comunicaçào na rede. Segundo Tanenbaum, em [TAN89], o anel "star-shaped" é uma proposta que apresenta uma solução para este problema. A idéia é ter um fio central como o centro das operaçōes, onde as interfaces das estações estão conectadas por dois fios, um para entrada e outro para saída dos dados. No fio central existe um elemento chaveador, um relé, que permite isolar parte do anel em caso de falha [COM91, TAN89].

Topologia em barramento [CLA78, GIOS6, STA84a].

A topologia em barramento é caracterizada pelo uso de um único canal de difusão, compartilhado pelas interfaces conectadas às estações (figura 2.4c). A decisão necessária em cada interface é a identificação das mensagens que săo destinadas à estação correspondente. 


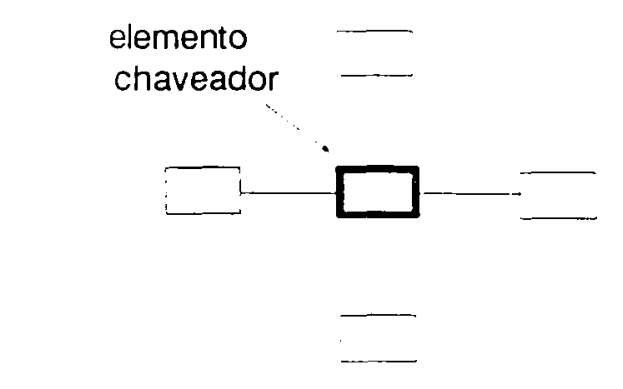

a) Estrela

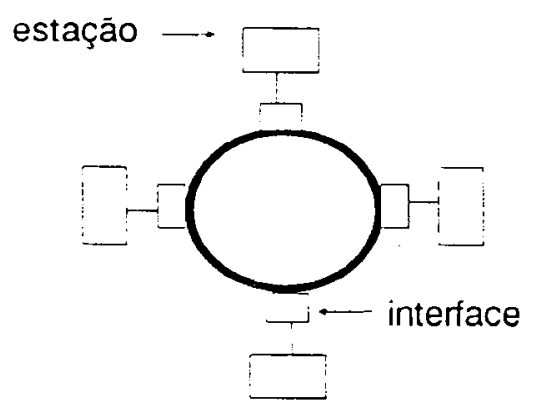

b) Anel

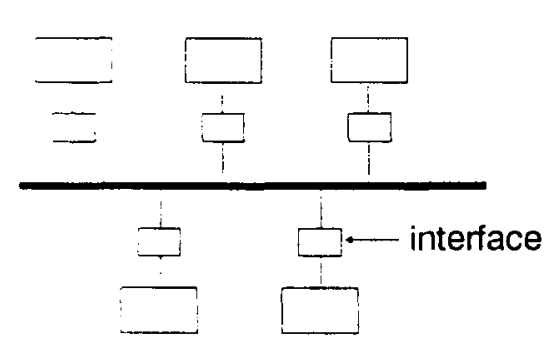

c) Barramento

Figura 2.4: Topologias básicas de redes locais [C LATB].

A topologia em estrela é bem adaptada a situaçòes onde o fluxo de comunicação é centralizado. isto é quando um certo número de estações se comunicam com uma estação central. A topologia en anel é relativamente simples e bastante adaptada às redes locais, onde o fluxo de comunicaçào entre as estaçòes tende a ser descentralizado. A topologia em barramento é facilmente reconfigurável e expandível na maioria dos arranjos físicos, tornando-a bastante utilizada em redes locais.

\subsubsection{Técnicas de controle de acesso ao meio}

As topologias em anel e barramento eliminam a necessidade de roteamento intermediário, permitindo a difusào de mensagens entre as estaçōes. entretanto, introduzem a necessidade de disciplinar a utilizaçào do recurso de transmissão comum às diversas estaçòes. Técnica de controle de acesso ao meio é a maneira pela qual as estações controlam o uso do canal para transmitir suas mensagens, podendo ser divididas em acesso baseado em disputa e acesso ordenado sem disputa [SOA86].

\section{Acesso baseado em disputa}

Nessa técnica nào existe uma ordem de acesso e nada impede que duas ou mais estações transmitam simultaneamente, provocando uma colisão e ocasionando assim perda das mensagens.

\section{CSMA (Carrier Sense Multiple Access).}

Na técnica CSMA. uma estação querendo transmitir escuta o canal de difusão para determinar se outra transmissão está ocorrendo. Por escutar o canal de difusão entendese que a interface da estação correspondente verifica a presença no canal de um sinal conhecido como portadora. Se este sinal não é detectado a estação pode transmitir, caso contrário ela espera por algum tempo e tenta transmitir novamente, utilizando um dos três algoritmos persistentes descritos a seguir [STA84a]: 
- Não prisistentr: a estaçào espera um periodo de tempo aleatório para entào escutar o meio nolamente:

- 1-persistente: a estaçào continua a escutar o meio até que ele fique livre e então transmite:

- p-persintente: a estaçào continua a escutar o meio até que ele fique livre e então transmite com una probabilidade prefixada $p$, ou espera durante um tempo determinado com probabilidade $1-p$.

O algoritmo nio persistente é eficaz em evitar colisòes. dado o tempo de espera ser aleatório. contudo. o canal poderá ficar inativo por um periodo de tempo. O algoritmo 1 persistente tent a reduzir o tempo inativo do canal. permitindo uma estaçào transmitir logo que o canal ticue illativo. Contudo. se mais de uma estaçào estiver querendo transmitir, uma colisào 2 garantida. O algoritmo p-persistente estabelece um compromisso de tentar minimizar colisoes e o tempo inativo do canal.

A técnica utilizada com maior freqüência na topologia em barramento é o CSMA/CD (Carrier Sense Multiple Access with Collision Detection), onde a estaçào continua a escutar o meio durante a transmissão. O CSMA/CD supera o CSMA pois permite a detecção de colisões imediatamente após sua ocorrência. O CSMA/CD adiciona algumas regras ao CSMA [GIOS6. STAS4a]:

- Se uma colisão é detectada durante a transmissão. cessa-se a transmissão e um sinal de interferência é transmitido para assegurar que todas as estações fiquem cientes da colisão:

- Depois de transmitido o sinal de interferência, espera-se um tempo aleatório e tentase transmitir novamente, utilizando CSMA.

\section{Acesso ordenado sem disputa}

O problema de colisào das mensagens é evitado, pois apenas uma estação por vez tem permissão de utilizar o meio durante um intervalo de tempo limitado.

Passagem de permissão ("token") [GIO86, MOU86, STA84a].

Esta técnica é baseada na existência de um pequeno pacote que circula através da rede, o "token", regulando a inserção de mensagens. A técnica tem implicações importantes no desempenho da comunicação: a mensagem pode ter tamantio variável, sendo restringida pelo tempo de permanência com o "token" e há a possibilidade de determinar o tempo máximo de espera para o acesso ao meio. 
Passagem de permissão ("token") em barramento [GIO86. LAGS6, STA84a].

Nessa técnica de controle é necessário implementar um mecanismo de ordenaçào cíclica das estaçòes. formando $1 \mathrm{~m}$ anel lógico. Quando uma estaçào recebe o "token", ela adquire o controle do barramento por um tempo determinado (tempo de permanência com o "token"). ou passia o "token" para sua estaçào sucessora. Cada estaçào tem o endereço de sua estaçào predeccssora de quem ele recebe o "token" e da sucessora para quem envia o "token".

Passagem de permissão ("token") em anel [GIO86. MOOL86. STA84a].

Uma estaçio guerendo transmitir espera pela passagem do "token" com permissão livere altera sira permissào para ocupado e transmite os dados. Quando terminar a transmissào. a estaça inscre un "token" com permissăo liere [STASta].

\section{Quadro vazio ("Empty slot") [GIOS6. LAG86. MIOL86. STA8ta]}

Essa técnica é baseada na existência de quadros de tamanho fixo. circulando continuamente no anel. (ada quadro possue um cabeçalho e uma área de dados. O cabeçalho delimita os quadros sucessivos e indica se o quadro está cheio ou cazio. Uma estação querendo transmitir deve aguardar a passagem em sua interface de um quadro vazio, marcá-lo como cheio e inserir sua mensagem na área de dados. A estação não pode transmitir outra mensagem até o quadro retornar e ser liberado. A liberaçào do quadro é efetuada pela estaçào transmissora.

Tem-se que esta técnica possibilita enviar mensagens de tamanho fixo (limitadas pelo tamanho da área de dados), e o acesso simultâneo de estaçòes ao canal de comunicação [GIO86]. O Anel de C'ambridge é o exemplo mais conhecido de uma rede local utilizando a técnica de quadro razio. sendo cada quadro de 40 bits. com 16 bits de dados [COU88, GIOS6, LAR82. SOA86. STA84a, TAN85].

\subsubsection{Um exemplo de rede de comunicação: a rede Ethernet}

A rede Ethernet começou a ser definida em 1972, no centro de desenvolvimento da Xerox em Palo Alto, nos Estados Unidos [MET76]. Em 1980, um esforço conjunto da Intel, Dec e Xerox resultou na especificação conhecida como Blue Book Ethernet, ou padrão DEC/INTEL/XEROX [FTP89, SHO82]. Em 1985, essa especificaçào foi modificada resultando no padrão IEEE 802.3, embora o padrão DEC/INTEL/XEROX continue sendo o mais utilizado.

Algumas das principais características da rede Ethernet são [COM91, COU88, GIO86, LAG86, METi6. SHO82, SOA86, TAN89, TAR86]:

- Técnica de controle de acesso ao meio de transmissão: CSMA/CD (Carrier Sense Multiple Access - Collision Detection);

- Topologia: barramento; 
- Taxa de transmissaro: 10 Mbits/s:

- Baixa eficiência a altas cargas de trabalho:

- Número máximo de cstaçòes numa única rede: 102:

- Sào normalmente utilizados dois tipos de cabos:

- Cabo grosso:

- Cabo fino:

- Sistema de sinalizaçào: Manchester encoding con voltagem alta e baixa, respectiramente. +0.8.5 V e - $0.5 .5 \mathrm{~V}$ :

- Endereços Ethernet: 6 bỵtes (todos os bits em 1 enviam a mensagem a todas as estaçōes ("broadcasting"));

- elementos da configuraçào usual:

- "transceiver" - circuito para detectar transmissào e colisào. A distância máxima entre dois "transceivers" numa mesma rede é de $2.5 \mathrm{Km}$. e nenhum caminho entre eles pode atravessar mais que quatro repetidores.

- "cabo transceiver" - conecta o "transceiver" à placa de interface no computador. Deve ter tamanho inferior a $50 \mathrm{~m}$.

- "placa de interface" - efetua transmissào e recepçào das mensagens, checando sua recepçào.

- Formato padrào do pacote Ethernet (figura 2.5):

Preâmbulo

End. destino End.origem *

dados

CRC

8 bytes

6 bytes

6 bytes

2 bytes

2 bytes

Figura 2.5: Pacote Ethernet [MET76, TAN89].

Tamanho máximo do pacote: 1526 bytes. Tamanho mínimo do pacote: 72 bytes.

Preâmbulo: 0 e 1 alternados, que auxilia na sincronização do destinatário.

* : no padrão DEC/INTEL/XEROX corresponde ao tipo do pacote. No padrão IEEE 802.3 corresponde ao tamanho dos dados.

$C R C$ : Cyclic Redundancy Code, auxilia a interface a detectar transmissão com erro. 


\subsection{Considerações finais}

Em um sistema distribuido. os usuários năo fazem distinçào entre operaçōes locais e remotas. O sistema pode apresentar uma série de vantagens. Entre elas destacam-se a possibilidade de obtençào de alto desempenho e o compartilhamento efetivo de recursos e informaçòes. O paradigma do cliente/servidor é a base para muitas das comunicaçóes entre processos em um sistema distribuido. O cliente pode ter acesso a recursos em qualquer servidor. sem tomar conhecimento em qual servidor estào os recursos ou onde está o servidor.

Redes locais tèm passado por uma evoluçào rápida nos últimos anos, motivada principalmente pela necessidade de compartilhar recursos computacionais de custo elevado e informaçòes. com alta confiabilidade e preservando a independência das várias estaçōes. Embora várias topologias tenham sido propostas. atualmente as mais utilizadas sào o anel e o barramento. As técnicas de controle de acesso baseado $\mathrm{cm}$ disputa, apesar de mais eficientes comparadas com as de acesso ordenado sem disput a. nào oferecem garantia deterministica de acesso.

Redes locais de computadores tornaran-se muito populares. podendo ser encontradas em praticamente todo tipo de organizaçào, desde indústrias. empresas comerciais, até universidades. Apesar de redes locais poderem funcionar de forma independente, a tendência é que ocorra interconexào entre as redes locais, as redes metropolitanas (MAN) e as redes de longa distância. 


\section{Capítulo 3}

\section{Protocolos}

Este capítulo apresenta padròes e protocolos, que procuram solucionar o problema de interconexăo de equipamentos e redes. O conjunto de regras e convençōes que disciplinam a troca de informaşòes entre usuários, sistemas ou redes de computadores é denominado protocolo de comunicaçào ou simplesmente protocolo. A revisào está organizada em três seçòes principais. abrangendo:

- Modelo de referència ISO/OSI;

- O padrão IEEE 802 para redes locais:

- O conjunto de protocolos TCP/IP.

\subsection{Introdução}

Organizaçōes internacionais de padronização, detectando a necessidade de uniformizar e assim viabilizar a comunicaçào entre equipamentos heterogêneos, há alguns anos desenvolvem esforços para especificar uma arquitetura padrão de protocolos de comunicação, aceita internacionalmente. Da experiência obtida nos projetos de redes, vários principios surgiram possibilitando que novos projetos fossem desenvolvidos de uma forma mais estruturada. Um desses principios é a idéia de estruturar o serviço de comunicação de uma rede como um conjunto de camadas hierárquicas, cada uma sendo construida utilizando as funções e os serviços oferecidos pelas camadas inferiores.

Dessa forma surgiram alguns modelos estruturados em camadas, sendo os principais o conjunto de protocolos TCP/IP (Transmission Control Protocol/ Internet Protocol) e o modelo de referência ISO/OSI (International Standards Organization/Open Systems Interconnection). $\mathrm{O}$ conjunto de protocolos TCP/IP foi implementado pelo DoD (Department of Defense) com o objetivo de interligar seus computadores em uma única rede, a Internet. A tecnologia desenvolvida foi subsidiada pela DARPA (Defense Advanced Project Agency) e interconecta organizações comerciais, internacionais e educacionais no 
mundo inteiro. () modelo de referência ISO/OSI visa servir de base para o desenvolvimento de sistrmus abertos. on seja sistemas que obedecom a padroes internacionais de comunicaçào. possibilitando ao usuário a interligaçào de qualquer tipo de computador, de qualquer fabricante. cutre si.

O CCITT (C'onité Consultatif Internacional de Télégraphique et Téléphonique) - entidade máxima cm termos de padronizaçào na área de telecomunicaçào de dados - aprovou um conjunto de rccomendaçòes relacionadas com o funcionamento de redes públicas de comunicaçào de dados. operando na modalidade de comutaçào por pacotes. Esse conjunto de recomendaçòs ś encabeçado pela recomendaçào X25. que define o funcionamento das três camadas inferiores (camada física. camada de enlace de dados e camada de rede do modelo de referencia ISO/OSI) nos equipamentos de redes públicas de comutação por pacotes [STASta. T:1.S9]. A adoçào do modelo de referencia ISO/OSI pelo CCITT foi um passo importante na sua consolidaçào. Diversos paises já se manisfestaram oficialmente no sentido de adotar o modelo de referência ISO/OSI. podendo-se citar os Estados Unidos. França. Iuglaterra. Japào e Brasil.

A idéia básica da estruturaçào em camadas é que cada uma das camadas forneça serviços de comunicaşà à camada imediatamente superior e receba os serviços fornecidos pelas camadas inferiores. que são sucessivamente ampliados e aperfeiçoados, para que na camada de nivel mais alto seja oferecido um conjunto de serviços, adequados para dar suporte a diversas aplicaçòes [TANS9]. Existem algumas vantagens práticas na utilização de uma estrutura em camadas [MOUS6]:

- A complexidade do desenvolvimento é reduzida através de abstrações. Não interessa para uma determinada camada como as demais implementam os serviços fornecidos, só interessa o que a camada oferece como serviço;

- A independência entre as camadas. A camada $N$ preocupa-se em utilizar os serviços da camada $\mathrm{N}-1$ e fornecer serviços à camada $N+1$.

\subsection{Modelo de referência ISO/OSI}

O modelo ISO/OSI é formado por sete camadas, não sendo especificado exatamente quais protocolos devem ser usados, mas sim a função de cada camada. O objetivo de se estruturar um protocolo em níveis é delimitar e isolar funções de comunicação em camadas. As setes camadas do modelo ISO/OSI são apresentadas a seguir em ordem crescente de nivel (figura 3.1) [COM91, COU88, GIO86, TAN89, TAR86]: 


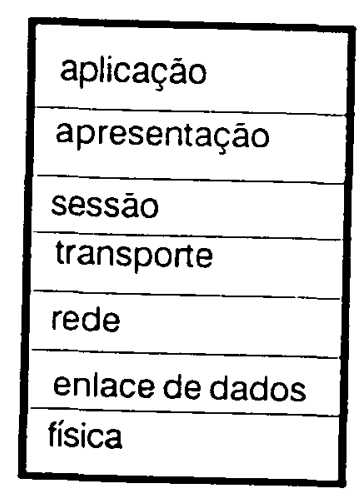

Figura 3.1: Modelo ISO/OSI [TAN89].

1. Camadu finicu: define as características mecânicas (tais como. tipo de cabo e conector). clétricus (como representar 0's e 1's), funcionais (tais como. duraçào de um bit, como a conexio será estabelecida e desfeita) e procedimentos para ativar. manter e desativar conexòes físicas.

2. Camada de enlace de dados: detecta e corrige erros que possam ocorrer na troca de informaçoes a nivel da camada física. A unidade de transferência de informação é uma seqüència de bits formando um "frame", transmitidos sequencialmente. Fornece controle de fluxo de dados, de modo a controlar a taxa de transferência de informaçào.

3. Camada de rede: fornece endereços a nível de rede para que os processos da camada de transporte possam se identificar mutuamente. A unidade de informação é o pacote de clados. originário da segmentaçào da mensagem, contendo os endereços origem e destino. seguido dos dados. Determina como pacotes săo roteados e fornece um controle de congestionamento, determinando o melhor caminho para a transmissào dos pacotes.

4. Camada de transporte: divide a mensagem em unidades menores (pacotes) e assegura que essas unidades cheguem corretamente à máquina destino. Dois tipos de serviços podem ser fornecidos: com conexão ou sem conexão, no primeiro é estabelecido um canal lógico entre as estações origem e destino, no segundo os pacotes são roteados a cada estaçào intermediária.

5. Camada de sessão: permite aos usuários em máquinas diferentes estabelecer sessões. Uma sessào permite que um usuário ao ter acesso a uma máquina possa ter acesso remoto a outra máquina ou transferir arquivos entre elas. Fornece um serviço de sincronizaçào, ou seja, quando uma transferência de arquivo é abortada, permite que ao ser reiniciada. recomece do ponto em que parou. Realiza transformações nos dados antes de seu envio, tais como, conversão de padrões e compressão de texto.

6. Camada de apresentação: efetua conversões para possibilitar a transmissão de dados entre computadores, pois vários tipos de representação de dados podem ser utilizados. Preocupa-se com a sintaxe (formação dos dados e níveis de sinais) e com a semântica (significado dos dados, a fim de fornecer um controle de informação e tratamento de erro) dos dados trocados. 
7. C'amada de aplicagcio: fornece serviços aos usuários do ambiente OSI, tais como, correio alentrico. protorolo de transferencia de arquivos. gerenciamento de rede, identificaçio a autenticaçào dos usuários.

Existem atualmente um número clevado de redes no mundo inteiro. A interconexão dessas redes f unna questào importante para a troca eficiente de informaçòes. No modelo de referência 1 SO/OSI a interconexào é realizada na camada de rede. Se as camadas de redes entre as redes conectadas forem diferentes é necessário efetuar uma permuta entre os protocolos utilizados nesse nivel, permitindo assim que a mensagem passe de uma rede para outra. I'ma organizaçào interna da camada de rede foi definida para possibilitar a interconexào [T. MS. TARS6]:

- sub-camadr de acesso: atua sobre o protocolo da camada de rede para uma rede especilica. Essa camada gera e recebe pacotes de controle e dados, executando as funçós relacionadas à camada de rede:

- sub-ramade de melhoria: é projetada para harmonizar a comunicaçào entre redes que oferecem scrviços incompatíveis. Permite que a sub-camada de retransmissão opere de forma independente das redes utilizadas:

- sub-camada de retransmissão: é responsável pelas funçòes executadas pelas camada de rede (redirecionamento e encaminhamento), independente da rede sendo utilizada:

Para efetivar a interconexào de redes de computadores, três tipos de retransmissores podem ser utilizados. dependendo das diferenças entre as redes [COM91. GIO86, TAN89, TAR86]:

- diferença na camada física: repetidor; equipamento que copia os bits entre segmentos do meio de transmissão;

- diferença na camada de enlace de dados: ponte; sistema que armazena e retransmite os pacotes de dados. Efetua verificação dos dados, podendo ser utilizada para interligar redes locais separadas geograficamente ou isolar dois segmentos de redes;

- diferença na camada de rede: roteador; sistema que armazena e transmite pacotes entre redes. mas nào efetua a conversão de protocolos.

- diferença na camada de rede: "gateway"; sistema que armazena e transmite pacotes entre redes distintas. Se necessário efetua mudanças nos protocolos ou endereçamentos possibilitando a comunicação.

O termo "gateway" é utilizado no sentido genérico para designar um retransmissor, entretanto, ele é um sistema bastante complexo, utilizado principalmente para interconectar redes com endereçamentos diferentes. A complexidade de um "gateway" depende principalmente da similaridade entre os protocolos das redes interconectadas. 


\subsection{Padrão IEEE 802 para redes locais}

O modelo $I S() /() S I$ foi elaborado para redes de longa distância. que utilizam um canal de interconexáo ponto-a-ponto o o princípio armazena e envia (onde uma mensagem para ser entregue ao list inatário necessita ser armazenada por estaçoes intermediárias, até que possa ser remelida) [SOA86. STA84a. TARS6]. Em redes locais. esse princípio é pouco utilizado. pois na sua maioria elas utilizam um canal de difusào ou roteamento único. $\mathrm{O}$ comitê de padronizaçào de redes locais IEEE 802 (Institute of Electrical and Electronic Engineers) estabeleceu uma arquitetura compatível ao modelo ISO/OSI, mas orientada ao desenvolvimento de redes locais. Essa adaptaçào ao modelo ISO/OSI subdivide a camada de enlace de lackos (em duas sub-camadas como mostrado na figura 3.2a.

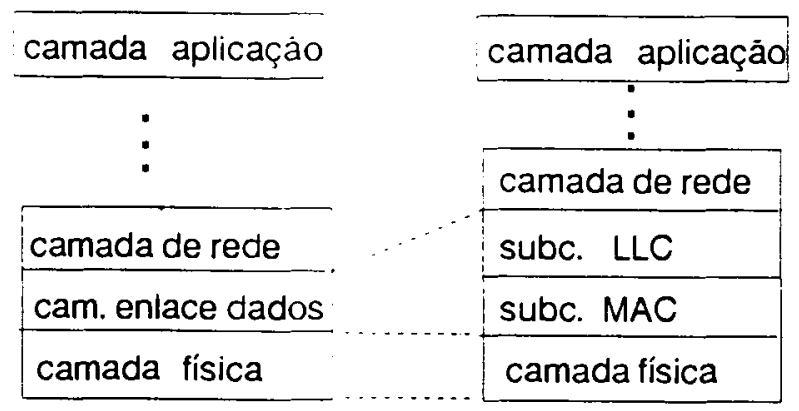

(a)

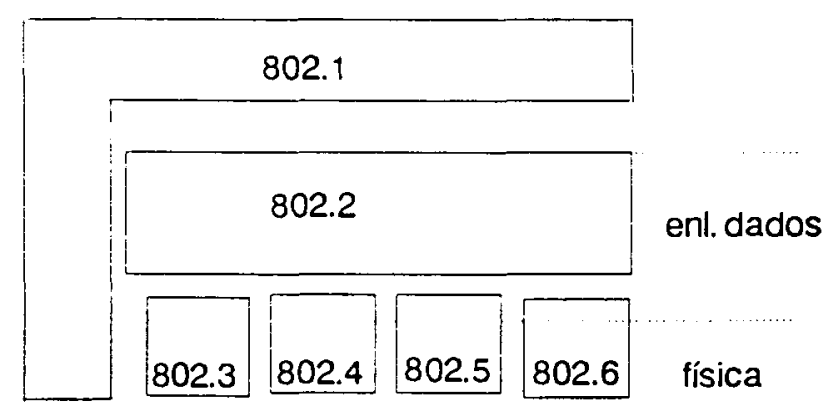

(b)

Figura 3.2: a) Modelo ISO/OSI e a arquitetura IEEE 802. b) Padrão IEEE 802 [TARS6].

- Sub-camuda LLC (Logical Link Control): fornece às camadas superiores dois tipos de serviços de entrega das unidades de dados [MOU86]:

- tipo $l$ - sem conexào. sem reconhecimento e sem qualquer controle de fluxo ou recuperaçào de erro. (A máquina origem envia "frames" independentes à máquina destino, sem esperar a confirmação de recebimento).

- tipo : - com conexào, reconhecimento, controle de fluxo, recuperação de erros e sequïenciaçào. (A conexão é estabelecida antes que qualquer dado seja transmitido. os "frames" são numerados, entregues uma única vez e são recebidos na ordem certa).

- Sub-camada MAC (Medium Access Control): fornece serviços que permitem disciplinar o compartilhamento de um meio de transmissão comum.

A subdivisào da camada de enlace de dados permite que a sub-camada LLC torne-se independente da topologia, do meio de transmissão e da técnica de controle de acesso ao meio utilizada.

O padrão IEEE 802 é um conjunto de padrões para redes locais de computadores, relacionados às camadas física e enlace de dados (figura 3.2b) [TAR86]. 
IEEE $802.1 \therefore$ um documento que descreve o relacionanento entre os diversos padrões IEEE 802. co relacionamento deles com o modelo de referência ISO/OSI.

Padrão IEEE 802.2: descreve duas interfaces oferecidas: uma da sub-camada LLC para a camarli derede e outra da sub-camada MAC para a camada física.

Padrão IEEE 802.3: Ć un padrão para redes em barramento. utilizando como técnica de commoli do acesso ao meio o CSMA/CD.

Padrão IEEE 802.4: ‘ um padrào para redes em barramento. utilizando como técnica de controle de acesso ao meio a passagem de permissào ("token").

Padrão IEEE 802.5: é um padrão para redes em anel, utilizando como técnica de controle do acrisu ao meio a passagem de permissăo ("tokien").

Padrão IEEE 802.6: especifica um padrào para redes metropolitanas (MAN's).

Atualmentr. ludos os padròes IEEE 802 apresentados acima procuram incorporar alternativas para o 11 so de fibras ópticas. O padrào FDDI (Fiber Distributed Data Interface) desenvolvido pela organizaçào de padronizaçào ANSI (American National Standards Institute), é o priméror padrào desenvolvido especialmente para redes locais com fibras ópticas e segue a arquituma. IEEE 802 [ROS90].

Os padròes IEEE 802 para redes locais apresentam algumas desvantegens. No padrão IEEE S02.3. a ansência de colisão das mensagens nǎo garante que a mensagem não foi alterada por ruídos na rede. necessitando que seja feita uma verificaçào na mensagem recebida. No padrào IEEE 802.4 , devem ser implementados mecanismos para os casos de falhas no anel lógico. perda do "token" e para prevenir a existência de vários "tokens" no anel lógico. To padrào IEEE 802.5, devem ser implementados mecanismos para evitar casos como a perda do "token" e a ocorrência de pacotes "órfãos". Tanenbaum, em [TAN89]. apresenta várias técnicas para solucionar esses problemas.

\subsection{O conjunto de protocolos TCP/IP}

O conjunto de protocolos TCP/IP, ou simplesmente protocolo TCP/IP, obteve uma maior divulgaçào após as duas iniciativas adotadas por agências do governo dos EUA [COM91]:

- Em 198:3. o Departamento de Defesa adotou o protocolo TCP/IP em sua rede privada (MIL`ET) e exigiu que todos os sistemas por ele adquiridos oferecessem suporte para esse protocolo:

- A DARPA financiou o desenvolvimento de uma versão extremamente bem difundida do sistema operacional UNIX (de Berkeley), chamada 4.2 BSD, que é a base do sistema Ultrix da DEC (Data Communications Equipment) e do sistema SunOS da Sun Microsvstems. É incluida uma interface ("sockets") que possibilita utilizar os 
protocolos [C.P E IDP, o que pode facilitar o desenvolvimento de software aplicativo empregando estes protocolos.

Há mais de dez anos, a tecnologia TCP/IP vem sendo utilizada para interligar um número sempre maior de redes. Nos primeiros anos. a Arpanet funcionava como sua espinha dorsal. por onde passava a maior parte do tráfego das informaçòes. Contudo, desde 1985, a Arpanet rem sendo substituida neste papel pela espinha dorsal da NSFNET, criada pela National Science Foundation para interligar centros de supercomputação financiados por ela e fornecer acesso remoto aos pesquisadores [COM91].

A Internet, cuja intençào original era facilitar o compartilhamento de recursos, a colaboraçào entre pesquisadores e fornecer um ambiente de teste para novos desenvolvimentos em rede. atualmente interliga o mundo todo. [COM91]. Tanenbaum. em [TAN89], atribue grande parte do atual estágio tecnológico de redes de computadores às pesquisas desenvolvidas na rede Internet. A arquitetura da Internet está organizada em quatro camadas conceituais e em uma quinta camada física (hardware) (figura 3.3). A unidade básica de transferência ć o "datagrama IP" ou simplesmente "datagrama", que é constituido de um cabeçalho e uma área de dados [POS81]. As camadas da arquitetura Internet são descritas a seguil [COM91]:

\begin{tabular}{|l|}
\hline aplicação \\
\hline transporte \\
\hline inter-rede \\
\hline interface de rede \\
\hline
\end{tabular}

Figura 3.3: Arquitetura da Internet [COM91].

\section{Camada de interface de rede}

Ela é responsável por receber e transmitir "datagramas" através de uma rede específica. A camada de interface de rede, às vezes denominada enlace de dados, fornece os meios de um hospedeiro ter acesso à rede, descrevendo o protocolo que possibilita a conexão e não o protocolo utilizado na rede. A interface de rede pode ser desde um mecanismo simples até um sistema complexo que utiliza seu próprio protocolo de enlace de dados para conectar-se à rede [COM91].

\section{Camada "internet"}

Aceita um pedido da camada de transporte para enviar um pacote, um "buffer" contendo os endereços origem e destino mais os dados. O pacote é encapsulado num "datagrama", o cabeçalho é preenchido e é utilizado um algoritmo de roteamento para determinar a entrega do "datagrama". Ao receber um "datagrama" a camada "internet" verifica sua validade, retira o cabeçalho e utiliza algoritmos de roteamento para decidir se os dados devem ser processados localmente ou retransmitidos. Os protocolos utilizados nessa camada são o IP e o ICMP. 
O protocolu IP (Internet Protocol) implementa duas funçòes básicas. endereçamento e fragmentaçào. A camada "internet" utiliza o endereço contido no cabeçalho para entregar o "datagrana". outros campos do cabeçalho sào utilizados para fragmentar e remontar os "datagramas". quando for necessário. O IP é nào confiável e possue um mecanismo de entrega sem conexào (nào existe uma conexào virtual entre as máquinas origem e destino). Nào é realizado controle de erros dos dados. somente a checagem do cabeçalho. não é feita retransmissào e nào existe controle de fluxo [COM91. HIN83. POS81, TAN89].

Se um "gatoway" nào pode retransmitir um "datagrama". ou se detectar uma condição de erro (como una rede congestionada que afeta a rota até o hospedeiro), ele utiliza o protocolo IC MP (Internet Control Message Protocol) para enviar as mensagens de controle a outros "gatewaỵs". aos hospedeiros ou à estaçào que enviou o "datagrama". O ICMP possibilita o (nuvio de mensagens para retardar o fluxo das mensagens vindas da estação origem e para lestar se a estaçào destino está disponivel [COM91. HIN83. TAN89].

\section{Camada de transporte}

Fornece comunicaçào entre programas de aplicaçào. segmentando a mensagem em pacotes. Essa camada pode regular o fluxo de informaçào e fornecer transporte confiável, assegurando que dados cheguem sem erro e na seqüência correta à máquina destino. A fim de realizar essas tarefas. espera um reconhecimento e retransmite o pacote caso necessário. Os protocolos de comunicaçào mais utilizados são o TCP e o UDP. Esses protocolos são desenvolvidos sobre os serviços do protocolo IP e possibilitam que múltiplos programas de aplicaçào comuniquem-se concorrentemente com programas de aplicação em outras máquinas [C'OMI91].

O protocolo TCP (Transmission Control Protocol) estabelece uma conexão antes de transmitir os dados, o que permite a troca de informaçōes em ambas as direçōes. O TCP implementa controle de fluxo de dados, onde o transmissor recebe uma mensagem especificando a quantidade de dados que o receptor pode receber. Contém mecanismos para fornecer transmissòes confiáveis que incluem números de seqüência, dígitos de verificação e temporizaçào [COM91, HIN83. TANS9].

O protocolo LDP (User Datagram Protocol) fornece transmissōes não confiáveis e sem conexão para a entrega de "datagramas", contudo é mais eficiente em termos de velocidade que o protocolo TCP. Na máquina origem o UDP inclue uma verificação dos dados a serem enviados, nào utiliza uma mensagem de reconhecimento e nào fornece controle de fluxo entre as máquinas [COM91, TAN89].

\section{Camada de aplicação}

Nessa camada os usuários utilizam programas de aplicaçào que tem acesso à Internet. Os programas de aplicação interagem com os protocolos da camada de transporte para enviar e receber dados. Os protocolos da camada de aplicação mais importantes são: o TELNET, o FTP e o SMTP [COM91].

O protocolo TELNET permite a um usuário estabelecer uma sessão em uma máquina remota - conexăo TCP para ter acesso a serviços em outra máquina, também possibilitando enviar mensagens da máquina local diretamente à máquina remota e vice-versa 
[COM91. POSS:3. TALS9].

O protocolo ITP (File Transfer Protocol) permite a um usuário autorizado ter acesso a um sistema remoto. identificar-se, listar diretórios remotos. copiar arquivos de/para máquinas remotas e executar alguns comandos remotamente (tal como. obter ajuda da sintaxe dos nomes dos arquivos na máquina remota) [C'OM91. CROS2. TAN89].

O protocolo S.ITP (Simple Mail Transfer Protocol) especifica como dois sistemas de correspondência eletrônica podem interagir, assim como o formato das mensagens de controle que eles utilizam para a transferência. A função básica do SMTP é fornecer um mecanismo de "ltgociação básica para a transferência de correspondência. Como o FTP, o SMTP é construido sobre os serviços do TCP [COM91. POS82, TAN89].

Atualmente. existem implementaçòes do conjunto de protocolos TCP/IP disponíveis em computadores na faixa compreendida de supercomputadores a microcomputadores, oferecendo um ambiente de rede robusto. estável e bem entendido pelos usuários e administradores. Existem rárias implementações de domínio público do conjunto de protocolos TCP/IP para microcomputadores, que podem ser obtidas com facilidade.

\subsection{Considerações finais}

A pesar de ter sido objeto de um grande esforço colaborativo a nível internacional desde 1980, a utilizaçào do modelo ISO/OSI é relativamente pequena, especialmente quando comparado com a arquitetura Internet. Esta situação certamente se modificará com o tempo, levando-se em consideraçăo iniciativas governamentais como US-GOSIP (U. S. Government Open Systems Interconnection Profile), que exigiram "suporte para o modelo ISO/OSI" dos seus fornecedores a partir de novembro de 1990. Algumas das principais redes compondo a Internet já estão se modificando para admitir o uso simultâneo do protocolo TCP/IP e do modelo ISO/OSI, encaminhando a transição para o modelo ISO/OSI.

A Internet baseia seus protocolos na idéia de que a confiabilidade é um problema a ser analisado pelas estaçǒes origem e destino, sendo a camada de transporte a que detecta algum erro e soluciona o problema. A liberdade resultante da verificação torna o software da Internet mais fácil de compreender e implementar, comparado ao modelo ISO/OSI [COM91]. O conjunto de protocolos TCP/IP tornou-se um padrão de fato, pois a experiência prática da Internet interligando sistemas heterogêneos conduziu a essa situação. $\mathrm{O}$ conjunto de protocolos TCP/ IP fornece a base para a Internet, contribuindo para a realização dos serviços fornecidos por essa rede. 


\section{Capítulo 4}

\section{Correio Eletrônico}

Este capítulo aborda os principais tópicos relacionados com correio eletrônico, estando organizado em três seçòes principais:

- Centralizado X Distribuído;

- Padronizaçào:

- Exemplos de sistemas existentes.

\subsection{Introdução}

A capacidade de entregar mensagens de costa a costa através de redes de computadores em poucos segundos, iniciou uma revolução na comunicação entre pessoas [TAN89]. Quando a Arpanet (que deu origem a Arpa Internet, que por sua vez se "diluiu" na Internet) iniciou sua operação (nos anos 70) seus projetistas esperavam que a comunicação entre processos imperasse sobre a comunicação entre pessoas, mas aconteceu justamente o oposto já que nem a neve, calor ou escuridão podem atrasar a entrega de uma correspondência eletrônica. Além da rapidez, o fato de possibilitar a comunicação sem as partes estarem disponíveis simultaneamente, permitindo a cópia, o armazenamento ou a retransmissão das mensagens, vem tornando essa opção de comunicação tão eficaz quanto o telefone e muitas vezes acaba pór superá-lo. Alguns sistemas de correio eletrônico permitem aos usuários criar caixas postais e/ou listas de distribuição (identificam grupos lógicos que deverão receber certos conjuntos de mensagens) [GRA83].

A correspondência eletrônica pode possuir características incomuns à transferência de arquivo, sendo tanto o transmissor quanto o receptor pessoas e năo máquinas. Esse fato tem resultado em sistemas de correio eletrônico divididos em uma interface com o usuário que permite a composição, a edição e a leitura das correspondências e uma entidade responsável pelo transporte das correspondências. As correspondências eletrônicas geralmente são divididas em duas partes: 
- envelope: que contém informaçòes necessárias ao transporte e interpretaçào da mensagem:

- corpo: sendo subdividido em cabeçalho e texto.

Com a finalidade de fornecer uma padronizaçào. o C.CITT definiu uma série de protocolos denominados MHS (Message Handling Systems) em sua série de recomendações $\mathrm{X} 400$. A ISO incorporou essas recomendaçòes na camada de aplicaçào do modelo ISO/OSI com o nome de MOTIS (Message-Oriented Text Interchange Systems) [TAN89].

\subsection{Centralizado X Distribuído}

Vários sistemas de correio eletrônico possuem uma configuraçào centralizada onde um usuário conecta-se a um computador central para enviar e receber correspondências [YU79]. Esse serviço geralmente segue o esquema descrito a seguir. sendo oferecido pelas companhias MCI Mail. CompuServe e RCA Mail, entre outras [ORT86]:

- a companhia mantém um computador central, onde executa um sistema de correio eletrônico que gerencia, armazena e redireciona as correspondências para as caixas postais dos destinatários. Caixa postal é um arquivo ou diretório no computador central;

- um usuário tem acesso ao computador central através de um software de interface que permite por exemplo: leitura, envio, retransmissão e armazenamento das mensagens.

Um fator competitivo entre essas companhias é a forma de tarifaçào, sendo em geral assumida como uma assinatura mensal considerando a quantidade de caracteres transmitidos, o tempo de conexão com o computador central e o tempo de armazenamento das mensagens. Algumas companhias oferecem bases de dados com serviços diversos, acesso as redes internacionais e permitem ao usuário preparar suas mensagens antes de se conectar ao computador central reduzindo assim o custo da conexão.

$\mathrm{Na}$ configuração distribuída alguns computadores efetuam as funções atribuidas ao computador central na configuração centralizada. Yu e Lambert propoẽm configurações distribuídas que sào apresentadas a seguir.

\subsubsection{Proposta de Yu}

Yu apresenta um esquema distribuído onde os usuários executam sistemas de correio eletrônico em seus microcomputadores. O roteamento de cada correspondência é efetuado por um conjunto de computadores denominados "salas de correspondências" que armazenam e remetem a correspondência para seu(s) destinatário(s). 
O cabeçalho da correspondència contém informaçòes de endereçamento e especificaçòes necessárias para retransmiti-la. tais como. remetente. destinatário. método de manipulaçào do corpo da correspondència. acesso a "sala de correspondência". informaçóes do caminho percorrido e informaçào da hora de envio [Y

Existem duas entidades básicas nessa proposta - MME e MTE (figura 4.1):

- MME - Mail Manager Entity: corresponde à interface com o usuário que permite enviar e receber correspondência. Consiste basicamente de cinco módulos:

- endereçamento:

- criaçào:

- registro para revisào, remoçằ. arquivamento e recuperaçào:

- transmissào e recepçào:

- funçòes de manutençào, tais como. gerenciamento de segurança de arquivos e reconfiguraçào do hardware.

- MTE - Mail Transfer Entity: recebe a correspondência do MME. enviando-a através da rede e entregando-a ao MME destino. Essa entidade pode ser composta por um conjunto de "salas de correspondências".

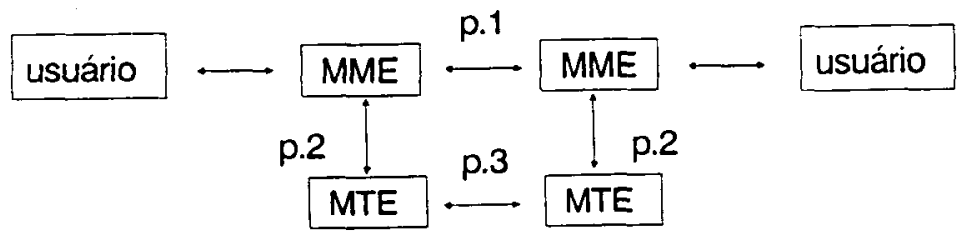

Figura 4.1: Esquema da proposta de Yu [YUT9].

Três tipos de protocolos são apresentados na figura 4.1 :

- p. 1: define a comunicaçào entre remetente e destinatário especificando informações, tais como, a identidade do remetente e do destinário, a identificação e a cifragem da correspondência, e a descrição do assunto;

- p. 2: define o envio (MME-MTE) e a entrega (MTE-MME) da correspondência entre as duas entidades;

- p. 3: define a comunicação, o armazenamento e o envio da correspondência através das MTE's. 


\subsubsection{Proposta de Lambert}

Lambert apresenta o PC'mail como um sistema distribuido de correio eletrônico que fornece serviços a um número arbitrário de usuários. A proposta principal do PCmail é [LAM88]:

- fornecer um serviço de correio eletrônico flexível, que varie de acordo com a potência computacional de cada estaçào. Os recursos considerados sào basicamente velocidade dos processadores e o espaço em disco:

- executar tanto em máquinas nào conectadas frequentemente à rede. como naquelas conectadas permanentemente.

O sistema é diviclido em duas partes - o repositório e o cliente (figura 4.2):

- repositório: é uma memória central para correspondências que chegam externamente através da Internet e internamente de outros repositórios on de clientes. $\mathrm{O}$ repositório mantém uma cópia da situaçào da caixa postal de cada usuário (denominada estado de correspondência global do usuário);

- cliente: fornece uma forma amigável de ter acesso ao estado de correspondencia global dos usuários. Im usuário pode ter um número arbitrário de clientes (frequentemente estaçòes). por exemplo um usuário pode ter um cliente em casa, outro no escritório. Cada cliente tem uma cópia do estado de correspondencia global de seus usuários. denominada estado de correspondência local. Os estados podem ser diferentes para clientes nào conectados permanentemente à rede sendo necessário sincronizá-los.

O cliente comunica-se com o repositório via o protocolo DMSP (Distributed Mail System Protocol) que fornece um conjunto completo de operações de manipulação da mensagem (tais como, enviar, remover e imprimir). O DMSP possue operações especiais que permitem fácil sincronização entre os estados de correspondências, sendo todas as operaçǒes atômicas.

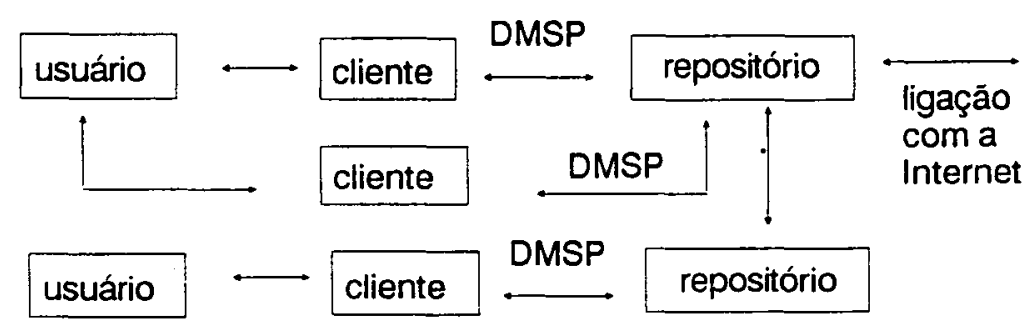

Figura 4.2: Esquema da proposta de Lambert [LAM88]. 
O PCmail permite dois modos de comunicaçào entre o repositório e o cliente:

- interativo: usado quando o cliente está conectado à rede com freqüência e qualquer mudança no estado cle correspondência local é imediatamente feita no estado de correspondência global e vice-versa:

- "batch": é usado por clientes que nào possuem acesso freqüente ao repositório. $O$ usuário muda o estado de correspondência local e quando o cliente é conectado ao repositório os estados de correspondências são sincronizados.

As correspondências sào divididas em duas partes: descritor e corpo. sendo respectiramente. um resumo que independe do comprimento da correspondência e o texto que inclue o "cabeçalho padrào" [CROS2] ( "from:". "to:". "date:" e "subject:") (seção 4.3.3). O descritor consiste le: palava descritor: linhas de controle contendo identificaçào da mensagem. sinais de controle. comprimento da mensagem em bytes e em linhas e o "cabeçalho padrào". Quando o cliente nào possuir memória suficiente para armazenar todas as mensagens ele pode obter alguns ou todos os descritores e solicitar o corpo das correspondências quando tiver memória suficiente. Logo, as conseqüuencias do uso de cliente com poucos recursos sào minimizadas pelo $\mathrm{PC}$ mail.

\subsection{Padronização}

Com a crescente necessidade de troca de informaçòes alguns sistemas de correio eletrônico foram elaborados de forma independente, gerando sistemas com correspondências incompativeis [VAU90]. A primeira organização a pesquisar a padronização de sistemas de correio eletrônico foi o IFIP (International Federation for Information Processing) que desenvolveu um sistema para troca de mensagens [RED8:3]. Esse sistema foi adotado pelo CCITT e pela ISO. Com a finalidade de padronizaçào, a Internet elaborou um sistema de domínios de nomes e endereços.

\subsubsection{Sistema MOTIS}

O sistema MOTIS concentra-se em todos os aspectos de um sistema de correio eletrônico da criação até a entrega da mensagem ao destinatário. Ele é composto basicamente pelo User Agent e pelo Message Transfer Agent (figura 4.3) [CUN84, CUN85, GRA83, HU86, RED83, SQU89, TAN89, TAR86].

O User Agent (UA) é um software que pode fornecer uma interface, um editor de texto e um sistema de arquivos para o sistema de correio eletrônico. Ele permite um usuário manipular sua caixa postal, compondo, enviando e recebendo correspondência.

O Message Transfer Agent (MTA) recebe mensagens de um UA origem e as retransmite ao UA destinatário. A coleção de MTA's é denominada Message Transfer System, onde um MTA seleciona outro MTA baseado nas informações do envelope e apresenta um sistema 
armazena-e-envia. Quando uma mensagem chega a um MTA. sua validade é verificada. Se for encontrado algum cro ela é enviada de volta com uma explicaçào. caso contrário é selecionado outro MT:I até que a mensagem possa ser entregue ao UA destinatário [CUNS4]. Os MTA's mantêm caixas postais para os usuários numa área denominada Message Store (MS). Nessa área as mensagens nào podem ser manipuladas pelos UA's sendo armazenadas até que o UA tenha acesso ao MTA correspondente, possibilitando assim a entrega (MT.1-(i.A) ou submissào (UA-MTA) das mensagens.

A ISO definiu protocolos para esse modelo [CUN84. CUN85. TAN89, TAR86]:

P1: protocolo entre MTA's.

P2: é definido para o cabeçalho e o texto. Refere-se a troca de mensagens cntre os usuários.

P3: possibilita a interaçào entre UA e MTA quando executam em máquinas separadas.

P7: possibilita a interaçào entre UA e MS.

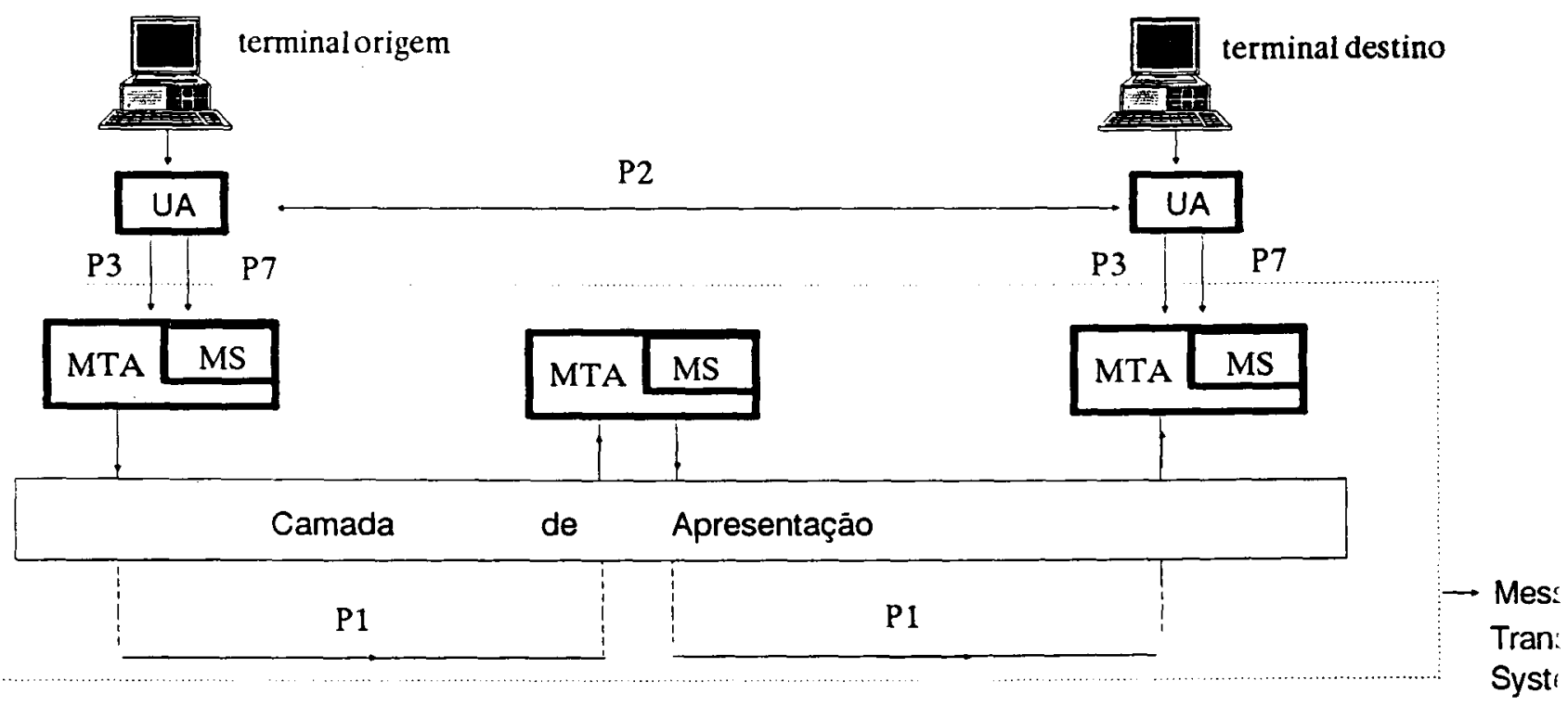

Figura 4.3: Modelo geral de um sistema de correio eletrônico [TAN89].

Como visto anteriormente, o sistema MOTIS baseia-se na série de recomendações X400 do CCITT, que é um padrão que permite aos usuários de sistemas de correio eletrônico transferir mensagens. A série é composta pelas recomendações apresentadas na tabela 4.1 [CUN84, CUN85, TAN89, TAR86, VAU90]. 


\begin{tabular}{||l||}
\hline X400 - Especifica o modelo de rede incluindo os UA's e MTA's. os serviços de \\
transferência de mensagens. os serviços de mensagens interpessoais e os proto- \\
colos das camadas. \\
\hline X401 - Lista os elementos básicos de serviços entre sistemas. \\
\hline $\begin{array}{l}\text { X408 - Especifica os algoritmos utilizados para conversào de diferentes tipos de } \\
\text { codificaçào de informaçào. }\end{array}$ \\
\hline $\begin{array}{l}\text { X409 - Define a técnica de notaçào e representaçào utilizada para especificar e } \\
\text { codificar as unidades dos protocolos. }\end{array}$ \\
\hline $\begin{array}{l}\text { X410 - Especifica como o X400 encaixa-se no modelo ISO/OSI bem como, al- } \\
\text { gumas técnicas que dào suporte às especificaçòes dos protocolos P1 e P3. }\end{array}$ \\
$\begin{array}{l}\text { X411 - Especifica os protocolos da sub-camada de transferência de mensagem } \\
\text { na camada de aplicaçào (P1 e P3). }\end{array}$ \\
\hline X420 - Especifica o protocolo P2. o cabeçalho e o tipo do corpo da mensagem. \\
\hline $\begin{array}{l}\text { X430 - Descreve o modo de acesso de terminais teletex ao sistema de tratamen- } \\
\text { to de mensagens. }\end{array}$ \\
\hline \hline
\end{tabular}

Tabela 4.1: Série de recomendações X400 do CCITT.

$\mathrm{O}$ processo de endereçamento utilizado na série de recomendações $\mathrm{X} 400$ atribue como endereço a um usuário um nome no formato $\mathrm{O} / \mathrm{R}$ (Originator/Recipient). Um nome no formato $\mathrm{O} / \mathrm{R}$ segue a seguinte estrutura:

\section{"palavra chave:valor,palavra chave:valor"}

Cada "palavra chave", também referenciada por "atributo", representa um elemento do endereço. A ambigüidade dos nomes pode ser resolvida especificando tantas "palavras chaves" quantas forem necessárias [QUA86, TAN89, VAU90]. Muitas empresas de sistemas de correio eletrônico utilizam o formato $\mathrm{O} / \mathrm{R}$ para os seus endereçamentos, como a Telemail, a MCI Mail e a ATT Mail. A rede EARN (European Academic Research Network), que conecta universidades e centros de pesquisas na Europa, também utiliza o formato O/R. Para facilitar a consulta aos endereços é utilizado um "serviço de diretório" que permite procurar os endereços através de seus "atributos". Esforços internacionais visando padronizar o "serviço de diretório", resultaram nas recomendações $\mathrm{X} 500$ do CCITT, que fornece um padrão de sistema unificado para armazenamento dos endereços no formato $\mathrm{O} / \mathrm{R}$ [ORD91].

Apesar do X400 ter se tornado um padrão internacional, como uma implementação para endereçamento no sistema MOTIS, a grande maioria dos sistemas de correio eletrônico utilizam o DNS elaborado pela Internet, apresentado a seguir. 


\subsubsection{DNS - Domain Name System}

O DNS é um mecanismo que implementa a hierarquia dos nomes das máquinas na arquitetura Internet. Conceitualmente. o DNS tem duas funçòes principais: a primeira é especificar a sintaxe dos nomes e as regras para designar autoridade sobre os nomes, e a segunda especifica a implementaçào de um sistema computacional distribuído que relaciona eficientemente os nomes com endereços [COM91. S[: i 90 ].

Um domínio é um agrupamento administrativo. Cada domínio é responsável pela manutençào da informaçào nos seus subdominios (agrupamentos autônomos com direitos próprios). Os nomes no DNS consistem de uma seqüência de subdomínios separados por um caracter delimitador ("."). apresentando à esquerda o dominio local (ou hospedeiro) cà direita o dominio de mais alto nivel [SUS2].

\section{hospedeiro.domínio1.domínio2...domínion}

O DNS é distribuido entre um conjunto de servidores de nomes. Para cada domínio cxiste um servidor de nomes que gerencia o endereço dos servidores de nomes para os subdomínios e os nomes dentro do domínio [LAN86]. Alguns domínios de mais alto nível foram definidos como: COM (organizaçōes comerciais), EDU (instituições educacionais), GOV (instituiçòes do governo), MIL (grupos militares) e abreviaçōes de países. No Brasil o dominio de mais alto nivel corresponde a "br" [COM91, LANS6, QUAS6. TAN89].

A UUCP (UNIX for UNIX CoPy) rede acadêmica de UNIX nos Estados Unidos, Europa e Asia necessita que os usuários forneçam o caminho completo do hospedeiro origem ao hospedeiro destino na estrutura apresentada a seguir, onde o hospedeirol é conhecido pelo hospedeiro origem. o hospedeiro2 é conhecido pelo hospedeirol, e assim por diante [QUAS6, SUS2].

\section{hospedeiro1!hospedeiro2!...hospedeiron!usuário}

Vários delimitadores sào utilizados para separar campos nos endereços: @, \% e !. $\mathrm{O}$ uso correto desses delimitadores é essencial para que as mensagens sejam entregues [CROS2, LANS6, QUAS6].

Q: indica o primeiro endereço a ser alcançado. Se houver mais de um endereço usa-se o delimitador \%.

! : delimita hospedeiros na rede UUCP.

. : delimita domínios e subdomínios.

\subsubsection{Formato padrão das mensagens texto na Internet}

Em 1977, a Arpanet desenvolveu vários padrões para as mensagens texto enviadas entre usuários de sistemas de correio eletrônico. O resultado dessas pesquisas é o artigo técnico conhecido como RFC 822 ou padrão RFC 822 [COM91, CRO82, TAN89]. As mensagens são vistas como linhas de texto em caracteres ASCII, possuindo um cabeçalho 
e um corpo, com "carriage return/linefeed" para delimitar as linhas. O cabeçallo segue uma estrutura de campos. contendo as informaçòes necessárias para uma mensagem ser transmitida ao seu destinatário. O corpo da mensagem é simplesmente uma seqüência de linhas de caracteres ASCII. O RFC $\$ 22$ especifica principalmente o formato e a sintaxe do cabeçalho. sendo este denominado "cabeçalho padrào". A separaçào entre o "cabeçalho padrào" e o corpo da mensagem é feita através de uma linha em branco. Crocker, em [CROS2], apresenta a seguinte sintaxe para os campos do "cabeçalho padrào":

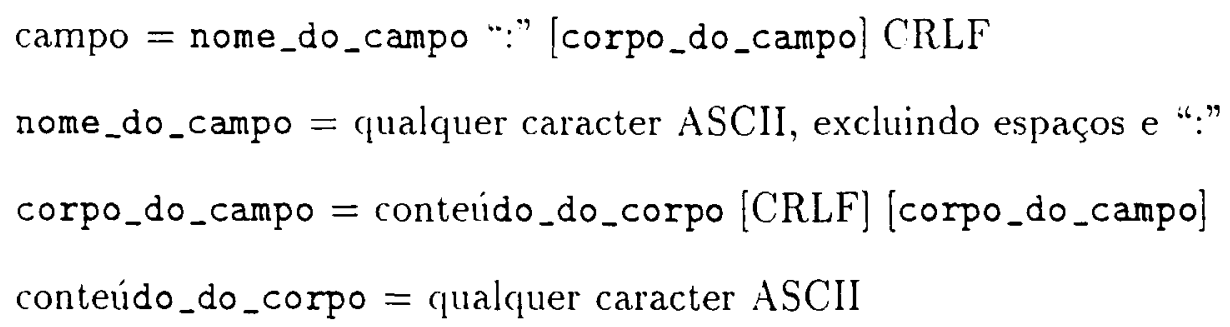

Segundo Tanenbaum, em [TAN89], o "cabeçalho padrão" é dividido em funções de envelope, endereços. conteúdo e outros. Alguns dos principais campos desses grupos são apresentados na tabela 4.2 .

\begin{tabular}{|c|c|}
\hline Campo & Descrição \\
\hline $\begin{array}{l}\text { Sender } \\
\text { To } \\
\text { Received from } \\
\text { Receive by } \\
\text { Receive with }\end{array}$ & $\begin{array}{l}\text { quem enviou, pode ser o nome do remetente, o nome do sistema ou } \\
\text { o nome do processo. } \\
\text { endereço do destinatário. } \\
\text { de onde a mensagem vem. } \\
\text { quem recebeu a mensagem. } \\
\text { o protocolo utilizado. }\end{array}$ \\
\hline $\begin{array}{l}\text { From } \\
\text { Reply-to } \\
\text { C.c } \\
\text { Bcc }\end{array}$ & $\begin{array}{l}\text { endereço do remetente. } \\
\text { endereço para onde deve ser enviada uma possivel resposta. } \\
\text { endereço secundário. Endereço para onde deve ser enviada uma } \\
\text { cópia da mensagem. } \\
\text { endereço secundário. Endereço para onde deve ser enviada uma } \\
\text { mensagem, sem o destinatário saber de sua existência. }\end{array}$ \\
\hline $\begin{array}{l}\text { In-Reply-To } \\
\text { References } \\
\text { Subject }\end{array}$ & $\begin{array}{l}\text { identificação da mensagem sendo respondida. } \\
\text { outras mensagens citadas. } \\
\text { assunto. }\end{array}$ \\
\hline $\begin{array}{l}\text { Date } \\
\text { Message-ID } \\
\text { Comment }\end{array}$ & $\begin{array}{l}\text { data de envio da mensagem. } \\
\text { identificador único da mensagem, gerado pelo hospedeiro origem. } \\
\text { comentário. }\end{array}$ \\
\hline
\end{tabular}

Tabela 4.2: Campos da "cabeçalho padrão" [TAN89].

O formato padrão desenvolvido pela Arpanet não visava indicar o formato das mensagens transmitidas internamente numa rede local, mas sim, organizar as informações necessárias para uma mensagem ser retransmitida entre diversos "gateways". 


\subsection{Exemplos de sistemas existentes}

Dois sistemas de corrcio eletronico para redes locais sào analisados a seguir.

\subsubsection{Sistema de correio eletrônico do sistema SunOS}

O sistema de correio eletrònico do sistema SunOS utiliza o despachador de correspondência Sendmail para entregar as mensagens, que derem seguir o padrào RFC 822 . O despachador Sendmail nào possue uma interface com o usuário e não entrega realmente as monsagens. ele coleta as mensagens a serem enviadas (utilizando o comando "mail" do sistema operacional ( NIX). compòe o endereço do destinatário conforme requerido pelo despachador destino e cliama os despachadores apropriados para efetuar a entrega ou o entilciramento para transmissào pela rede [SUN90, SUN91a. SLN91b, TRA91].

A configuraçào do Sendmail é efetuada pelo arquivo "/etc/sendmail.cf". o qual é lido pelo sistema ao iniciar suas operaçòes. Esse arquivo possue definiçōes de macros usados internamente. declaraçào de cabeçalhos (o formato das linhas do cabeçalho que serão processadas. e linhas que serào acrescentadas ou reformatadas). definiçoes de despachadores (informaçòes tais como. localizaçào e caracteristica de cada despachador), regras de reescrita (sistemas de regras para reescrever nomes) e opçòes (tais como: caminho para vários arquivos de suporte. "time outs" e modos assumidos). O despachador Sendmail requisita três tipos de máquinas (figura 4.4 ):

- pelo menos um "mailbox server":

- subsidiárias e

- um "mail host".

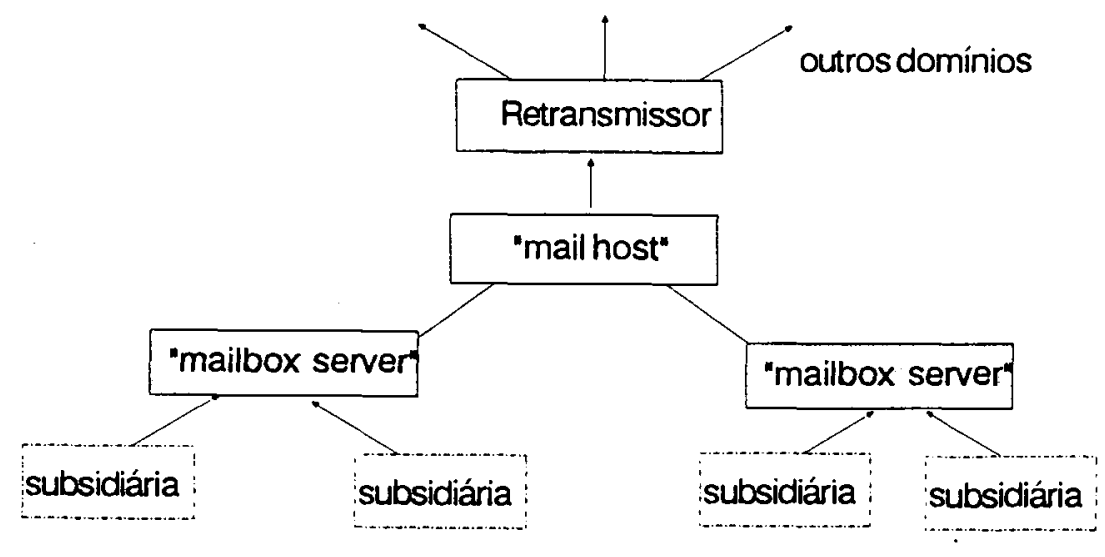

Figura 4.4: Máquinas requisitadas pelo despachador Sendmail [SUN90]. 
"mailbox server": máquina que armazena as cairas postais dos usuários no diretório "/rar/spool/mail". Ela armazena as mensagens enviadas pelas máquinas subsidiárias numa fila para entrega.

"mail-hosts": máquina principal num dominio para o recebimento de correspondència. A máquina adequada para exercer essa funçào é a máquina que possue interface com mais de uma rede.

subsidiárias: demais máquinas do sistema. Elas possuem como retransmissor a máquina "mail-host".

A máquina "mail-host" é utilizada pelas máquinas subsidiárias para retransmitir as mensagens que nào consegue entregar localmente. O retransmissor de domínio é utilizado pelo Sendmail da máquina "mail-host" para retransmitir as mensagens que nào consegue resolver no dominio local. O retransmissor de domínio corresponde a uma máquina em outro dominio a que se tem acesso. especificada no arquivo "/etc/sendmail.cf" da máquina "mailbox server". Algumas interfaces para o serviço de correio eletrônico estào disponíveis, uma das mais utilizadas é a interface "Mailtool".

\subsubsection{Sistema de correio eletrônico do sistema TRICE}

O sistema TRICE (TRansportable Integrated Computing Environment) é uma implementação do conceito de sistema computacional distribuído fracamente acoplado baseado em rede local que foi desenvolvido em Southampton, Inglaterra. Esse sistema adota o modelo estaçào de trabalho/servidor e o paradigma cliente/servidor. Um usuário numa estaçào de trabalho pode executar um programa "mail" residente no diretório padrão dos servidores de arquivos. Esse programa possibilita uma interface entre o usuário e o gerenciamento das correspondências [SAN89].

Ao executar o programa "mail" săo apresentadas as correspondências que se encontram no diretório padrão. na caixa postal do usuário e alguns comandos que podem ser executados com uma mensagem selecionada. O comando NEW apresenta as correspondências que o usuário nào leu. Os comandos FORWARD, REPLY e SEND ativam um editor de texto ( "SE" - Screen Editor), permitindo ao usuário compor sua mensagem. Para os comandos FORWARD e SEND devem ser fornecidos um ou mais endereços de destinatários separados por vírgula: "Who :".

Quando os comandos DELETE e MOVE são utilizados, as mensagens são marcadas e ao terminar a execuçào do programa (comando EXIT), elas são, respectivamente, apagadas e movidas. O comando MOVE possibilita mover correspondências que o usuário deseja guardar em um subdiretório denominado OLDMAIL. O usuário deve possuir esse subdiretório em seu diretório padrão. O comando OLD é utilizado para ter acesso a essas correspondências. $\mathrm{O}$ comando NEW pode ser utilizado para mover as mensagens do subdiretório OLDMAIL para a caixa postal do usuário. Os endereços fornecidos são sempre validados pelo programa "mail", podendo ser de três modos:

- local: para usuários no domínio ECSNET (Electronic and Computing Science Network). Pode-se fornecer apenas a identificação do destinatário; 
- apelido: o programa "mail" pesquisa um arquivo denominado "mailnames" no diretório padrào do usuário e efetua a traduçào para o endereço completo:

- completo: para correspondências destinadas a outros sistemas.

O comando SEND envia a correspondência para um diretório denominado "gateway" localizado num servidor de arquivo. O sistema TRICE está ligado a uma estaçào SUN de um outro sistema que é o responsável por gerenciar as mensagens no sistema TRICE e em outros subdomínios do domínio ECSNET. Esse sistema tem acesso ao sistema TRICE como se fosse um usuário e executa um programa que transfere todas as mensagens armazenadas nesse diretório para a estaçào SUN. usando kermit '. que entào encarrega-se de retransmiti-las.

As mensagens enderç̧adas ao sistema TRICE são armazenadas na estação SUN. A estaçào SUN conecta-se ao sistema TRICE, transferindo-as para o diretório "gateway" e executando um programa que as distribue entre os usuários. O acesso da estação SUN ao sistema TRICE é efetuado periodicamente, em intervalos de mais ou menos 2 minutos.

\subsection{Considerações finais}

Muitas empresas têm desenvolvido seus próprios sistemas de correio eletrônico seguindo uma das duas configuraçòes: centralizada ou distribuída. A configuração distribuída apresenta algumas vantagens: segurança (os usuários nǎo têm acesso a um mesmo computador central), o envio das correspondências é mais rápido (distribuição do gerenciamento dos endereços) e o custo é relativamente mais barato (decréscimo do custo do hardware e microcomputadores mais sofisticados que minimizam os custos em relação a uma configuração centralizada com um computador de grande porte). As propostas de Yu e Lambert têm um ponto em comum. As duas apresentam uma interface para a preparação, envio e recepçào das mensagens, o que salienta a importância de uma interface amigável num sistema de correio eletrônico.

$\mathrm{O}$ modelo desenvolvido pelo IFIP, assemelha-se à proposta de $\mathrm{Yu}$, sendo que o UA e o MTA do sistema MOTIS correspondem respectivamente as entidades MME e MTE na proposta de Yu. O desenvolvimento do DNS possibilitou uma troca de correspondência mais eficiente identificando unicamente um destinatário.

Sistemas de correio eletrônico são utilizados para possibilitar uma troca eficiente de correspondências. A maioria desses sistemas possuem uma interface amigável que facilita a sua utilização. Num sistema distribuído, o correio eletrônico pode ser implementado num servidor de correio eletrônico que além de poder fornecer uma interface amigável, gerencia as correspondências dos usuários do sistema.

\footnotetext{
${ }^{1}$ Kermit é um protocolo de comunicação de dados entre computadores cujas funções básicas são a de emular terminais e transferir arquivos [DVO89, GIA89]
} 


\section{Capítulo 5}

\section{Ambiente de implementação}

Nos capítulos anteriores. foram apresentados tópicos relevantes para o sistema desenvolvido. Neste capitulo algumas informaçōes relacionadas à implementaçăo do sistema servidor de correio eletrônico são apresentadas nas seguintes seçòes:

- Ambiente de utilizaçào;

- Mecanismo de acesso ao meio;

- Especificação do mecanismo de RPC;

- Uso de alias pelo despachador Sendmail.

\subsection{Introdução}

No Brasil, os esforços para interconectar as redes nacionais às redes internacionais iniciaram-se na década de 80 , com tentativas de se obter uma ligação à rede BITNET (Because It's Time NETwork), que interliga instituições de ensino superior e de pesquisa em vários países. A idéia central da rede BITNET é dividir os gastos e as responsabilidades entre os participantes. Cada um custeia sua ligação à rede e assume o compromisso de fornecer condições para que, no mínimo, um novo membro possa se conectar à rede através dele. Para se integrar à BITNET, a instituição deve instalar uma linha de comunicação de dados com um local já conectado à rede [LAN86, QUA86, MOR92]. A política da EMBRATEL (Empresa Brasileira de Telecomunicações) dificultou inicialmente a ligação do Brasil à BITNET, pois a legislação de telecomunicações impedia que o tráfego de mensagens originadas e destinadas a uma empresa pudesse ser comutado para o exterior ou do exterior para uma outra empresa.

Depois de várias tentativas, em i988, o LNCC (Laboratório Nacional de Computação Científica) tornou-se integrante dà rede BITNET através da Universidade de Maryland. No mesmo ano, a FAPESP passou a integrar a BITNET e a HEPNET (High Energy Physics Network). Essa ligação possibilitou à rede ANSP (Academic Network at São 
Paulo) o acesso aos diversos recursos disponiveis através da BIT NET. tais como, correio eletrônico. transferencia de arquivos. mensagens interativas. acesso a bases de clados e sistemas de listas de distribuiçào. A rede ANSP incluia inicialmente a USP. a UNI CAMP, a UNESP. o IPT (SP). a IFRGS e a UFMG. Em 1989. o Brasil adquiriu uma terceira ligaçào à BITNET. (quando a UFRJ ligou-se à UCLA (University of California. Los Angeles) [STA92].

Diante da convergincia na comunidade cientifica mundial para o uso do protocolo TCP/IP, existiram sistorcos para estabelecer um acesso brasileiro à Internet. Em fevereiro de 1991, a FAPESP ađłquiriu e instalou o software MULTINET. o qual viabilizou a ligação do Brasil à rede ES:I:T (Energy Sciences Network) e assim à Internet [GET92].

Existe uma tendencia internacional em organizar as redes de forma hierárquica, em três grandes niveis. com o objetivo de melhorar o fluxo das mensagens e dividir os custos (? as responsabilidade's [ [.1R92]:

Nível 1: uma espinha dorsal com o objetivo de conectar os centros provedores de serviços especiais às redes regionais:

Nível 2: redes regionais, em geral organizadas geograficamente em áreas metropolitanas. redes estaduais ou regionais englobando segmentos maiores:

Nível 3: redes intcrnas compostas de redes locais fornecendo serviços para uma entidade que é responsável pela implantaçào, custeio e operação da mesma.

Atualmente, a interconexão de redes tornou-se de tal forma difundida que ao se olhar macroscopicamente. tem-se a impressào de se ter uma rede global. Com a ligação do Brasil à rede BITNET e posteriormente à Internet, o serviço de correio eletrônico tornouse cada vez mais difundido no meio científico, e aos poucos os pesquisadores de diversas áreas se acostumaram com as facilidades por ele fornecida, possibilitando uma nova opção de comunicaçào. alcançando praticamente o mundo todo.

\subsection{Ambiente de utilização}

O servidor de correio eletrônico desenvolvido, inicialmente possibilita interligar uma das rede interna do ICMSC, o ambiente LASD, a outras redes através da ligação a um sistema distribuído SunOS, que por sua vez está interligado com as redes nacionais e internacionais. Posteriormente, o serviço de correio eletrônico poderá ser acrescentado aos vários ambientes existentes no ICMSC, como mostra a figura 5.1. 


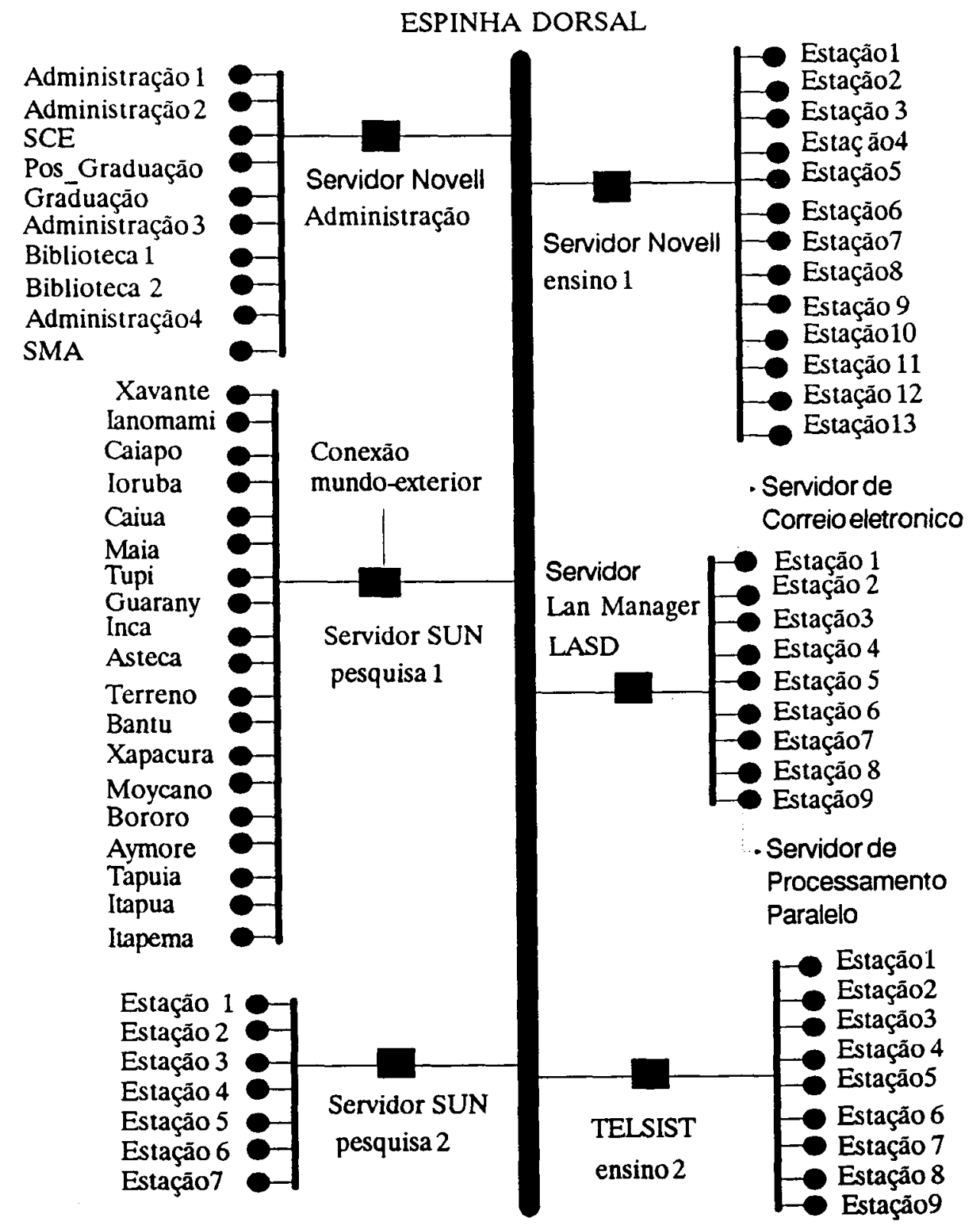

Figura 5.1: Ambiente das redes do ICMSC [SAN92].

O ambiente LASD é um ambiente para o desenvolvimento de pesquisas em sistemas computacionais distribuídos e computação concorrente, sendo composto por estações de trabalho Sun (SPARCStation SLC) sob SunOS e microcomputadores pessoais sob DOS. 
A comunidade de usuários é formada por pesquisadores e estudantes de graduaçào, mestrado e doutorado. O sistema distribuído SunOS do ICMSC é constituido de estaçóes de trabalho Sun (SPARCStation 2 e SLC) sob SunOS, sendo que o seu sistema de correio eletrônico (veja seçào 4.4.1 para maiores detalhes) possue a seguinte configuração:

"mailbox server" e "mail host" -> estaçào xavante:

subsidiárias $\rightarrow$ demais estaçòes.

O retransmissor de domínio utilizado pela máquina "mailbox server" é a estação Sun "floyd" do IFQSC (Instituto de Física e Química de Sào Carlos), a qual utiliza como retransmissor o computador USPFSC (VAX-Digital VMS). A ligaçào do ambiente LASD com as redes nacionais e internacionais é esquematizada na figura 5.2.

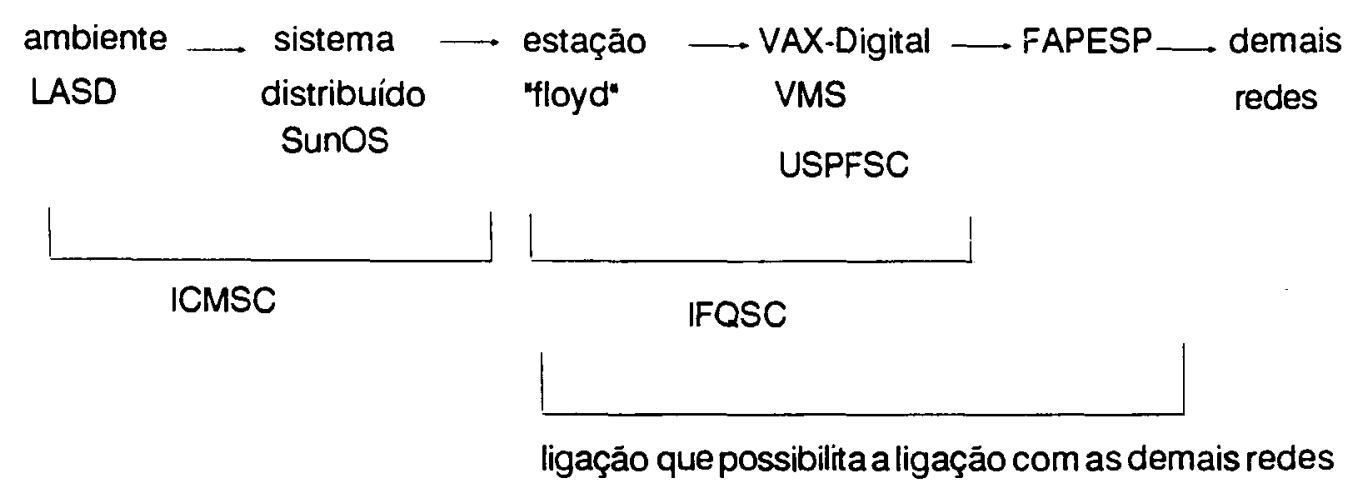

Figura 5.2: Ligação do ICMSC ao mundo exterior.

O servidor de correio eletrônico é composto por duas partes principais, seguindo o paradigma do cliente/servidor:

- o software servidor: executa os pedidos das estações clientes e fornece a interconexão com o sistema SunOS;

- o software cliente: fornece uma interface amigável com os usuários e gerencia a comunicação com o servidor. Uma interface amigável corresponde a uma interface de fácil compreensão de suas funções, apresentando um "layout" agradável ao usuário [MAR91].

A figura 5.3 apresenta uma visão geral do sistema. 


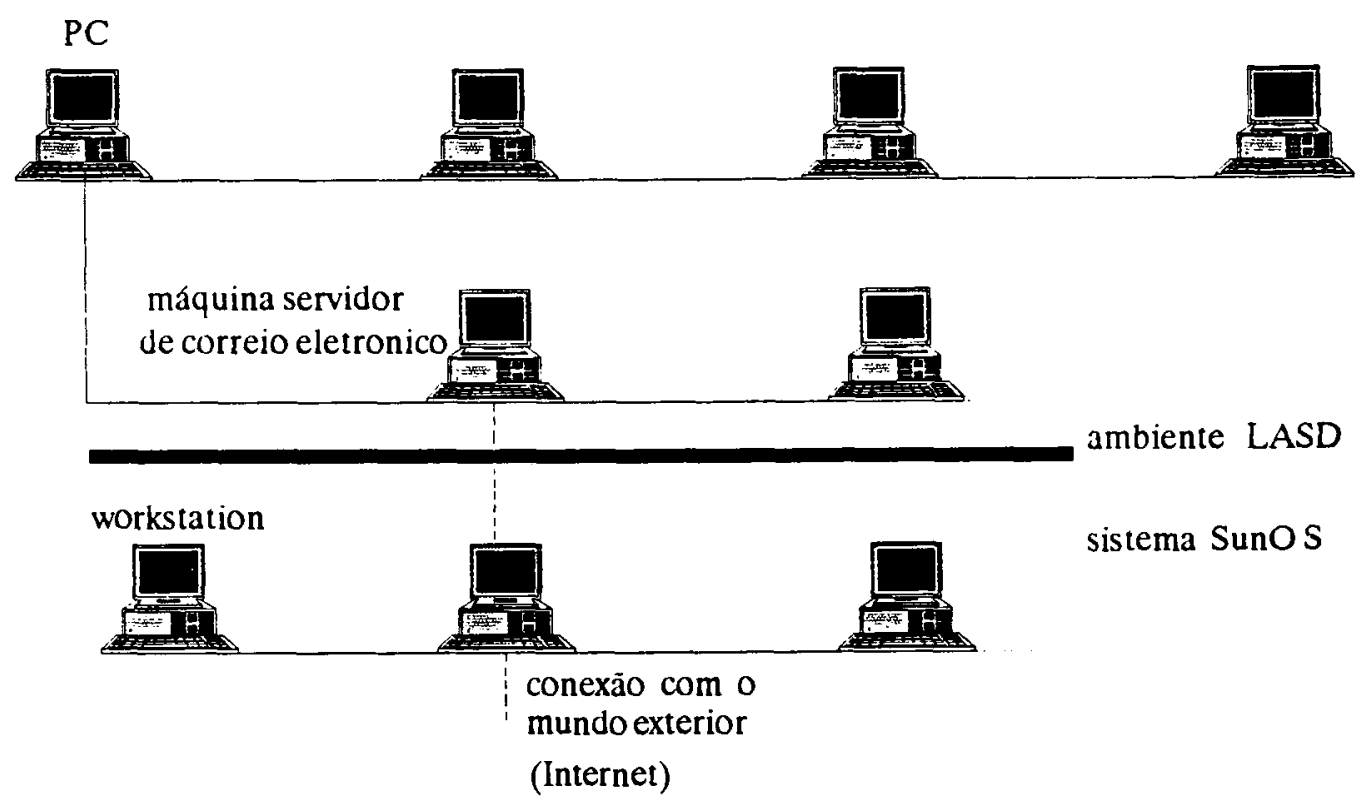

Figura 5.3: Sistema servidor de correio eletrônico.

O acesso aos recursos do servidor de correio eletrônico é feito através de um conjunto de primitivas que escondem os detalhes de implementaçăo. $\mathrm{O}$ usuário pode requisitar a execução de uma primitiva disponível no servidor. O servidor analisa a solicitação e envia uma resposta ou uma mensagem de erro. O usuário enxerga o sistema sob o ponto de vista de uma ferramenta para a utilização do serviço de correio eletrônico.

O compartilhamento do meio físico permite que diferentes estações possam se comunicar e, conseqüentemente, façam uso do servidor de correio eletrônico. O padrão Ethernet, operando a $10 \mathrm{Mbps}$, é usado como meio físico de transmissão para interligar as estações clientes e a estação servidor de correio eletrônico, e essa ao sistema SunOS.

\subsubsection{A rede ANSP}

A idéia da rede regional ANSP surgiu no final de 1987 e formalizou-se em 1988 na FAPESP. A partir de 1990, a rede ANSP passou a ser administrada permanentemente pelo centro de processamento de dados da FAPESP. A idéia inicial foi auxiliar as três Universidades paulistas estaduais (USP, Unicamp e Unesp) a possuírem conectividade interna e externa às redes de pesquisas. A ligação no exterior é estabelecida por uma linha internacional ao laboratório Fermi, em Illinois, EUA. Em 1989, a linha internacional estava operando a $4800 \mathrm{bps}$, e em 1990 a 9600 bps. As redes internacionais a que se têm 
acesso direto sào a Hepnet/Span. a BITNET e a Internet. A ligaçào com a Internet foi efetivada em leverciro de 1992 [GET92].

A rede ANSP instalou "gateways" nos principais pontos de sua espinha dorsal, elevando a velocidade da linha internacional e de algumas ligaçòes de sua espinha dorsal para 64 kbps. As principais instituiçòes que constitue a ANSP dentro do estado de São Paulo, além das três Lniversidades paulistas, sào o IPT (Instituto de Pesquisas Tecnológicas), - INPE (Instituto Nacional de Pesquisas Espaciais), a UFSCar (Universidade Federal de São Carlos), a PICCamp. a PUCSP. o CPQD - Telebrás, a Escola de Medicina da Sta. Casa de Misericórdia e a Escola Paulista de Medicina (figura j.t).

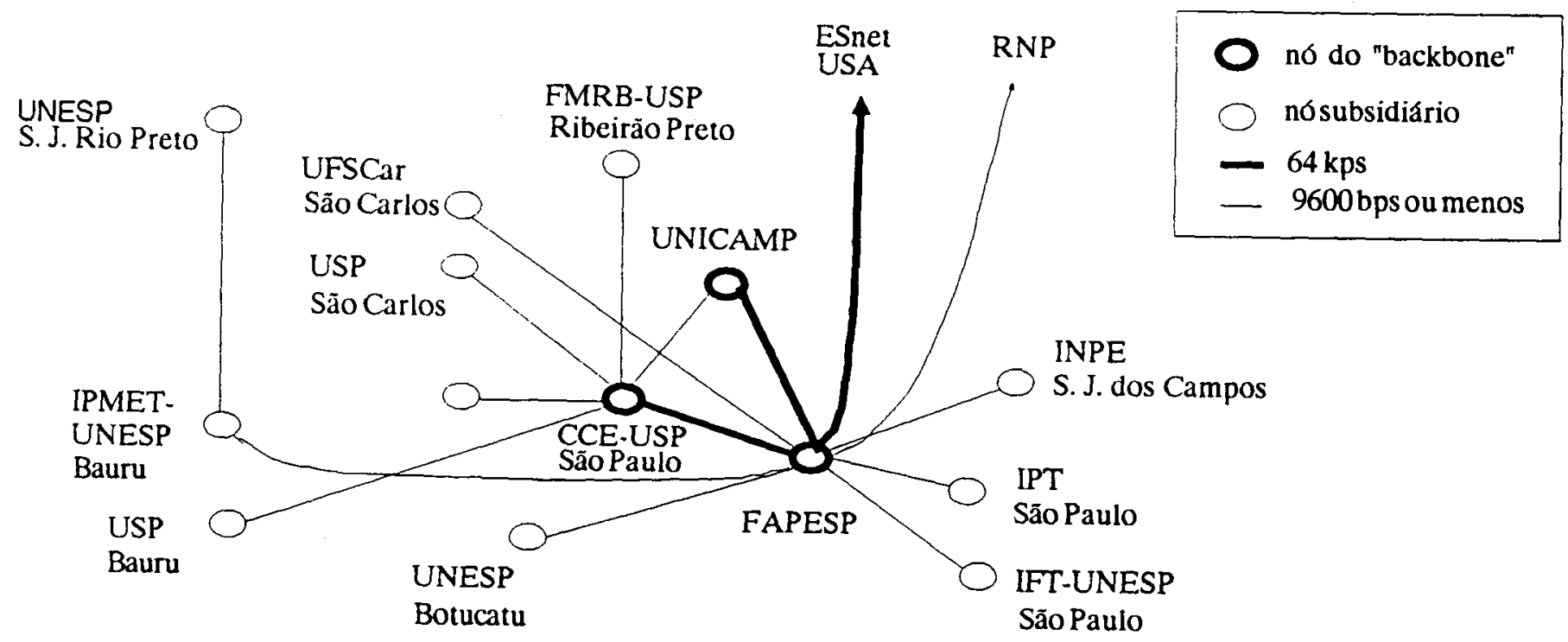

Figura 5.4: A topologia da rede ANSP em 1992 [GET92].

\subsection{Mecanismo de acesso ao meio}

Para a comunicação entre as estações clientes e a estação servidor de correio eletrônico, foi necessário usar um mecanismo que permitisse o compartilhamento do meio de transmissão e do tempo de processamento do servidor (o servidor atende várias estações ao mesmo tempo). Com este objetivo, foi utilizado o mecanismo de domínio público Packet Driver/NCSA disponível na Universidade de Clarkson (New York -USA). Esse mecanismo corresponde a uma parte da implementação do protocolo TCP/IP para microcomputadores PC's que implementa todos os procedimentos requeridos para dar suporte de acesso ao meio físico. As características principais do Packet Driver são [CLA89, FTP89, TRI91]:

- possibilita a transmissão de pacotes com endereços múltiplos e também "broadcast";

- possibilita uma interface padrão com as camadas superiores do software do sistema, tornando-as independentes das características do meio físico; 
- permite a execuçào de múltiplas aplicaçoes simultaneanente utilizando a mesma interface com o meio físico da rede local:

- os pacotes de dados nào relerantes para a aplicaçào sendo executada sào rapidamente descartados pelo Packet Driver. A aplicaçào somente recebe os pacotes destinados a ela.

O Packet Driver associa um tipo a cada pacote de dados. I'm pacote somente será processado se a recepçào para pacotes do seu tipo tiver sido previamente autorizada. Isso $\therefore$ feito por uma funçào do Packet Driver a qual associa ao tipo de pacote um identificador o uma rotina de recepçào especifica.

A operaçào básica do Packet Driver envolve três módulos: o Packet Driver, uma rotina para recepçào " tratamento de pacotes (ReceberPht) e o aplicativo. Quando um pacote válido é recebido polo hardware de in terface com o meio físico da rede. uma interrupção de software (int) é gerada e a execuçào é transferida para o Packet Driver. O Packet Driver analisa o tipo do pacote. descartando-o ou prosseguindo com a sua transferència em funçào dessa análise. I rotina de recepçào pode aceitar a transferência do pacote ou descartá-lo. No primeiro caso. o Packet Driver transfere o pacote para o "buffer" especificado pela rotina de recepçào. devolvendo em seguida o fluxo de execuçào novamente para a rotina de recepção. para um eventual processamento do pacote. UI ma vez processado, o fluxo de controle volta novamente para o Packet Driver, que finalmente transfere a execução para o aplicativo. No segundo caso, a execuçào é transferida para o Packet Driver, que por sua vez, transfere a execuçào para o aplicativo [TRI91]. A figura 5.5 mostra o mapa de estados da operaçào básica do Packet Driver.

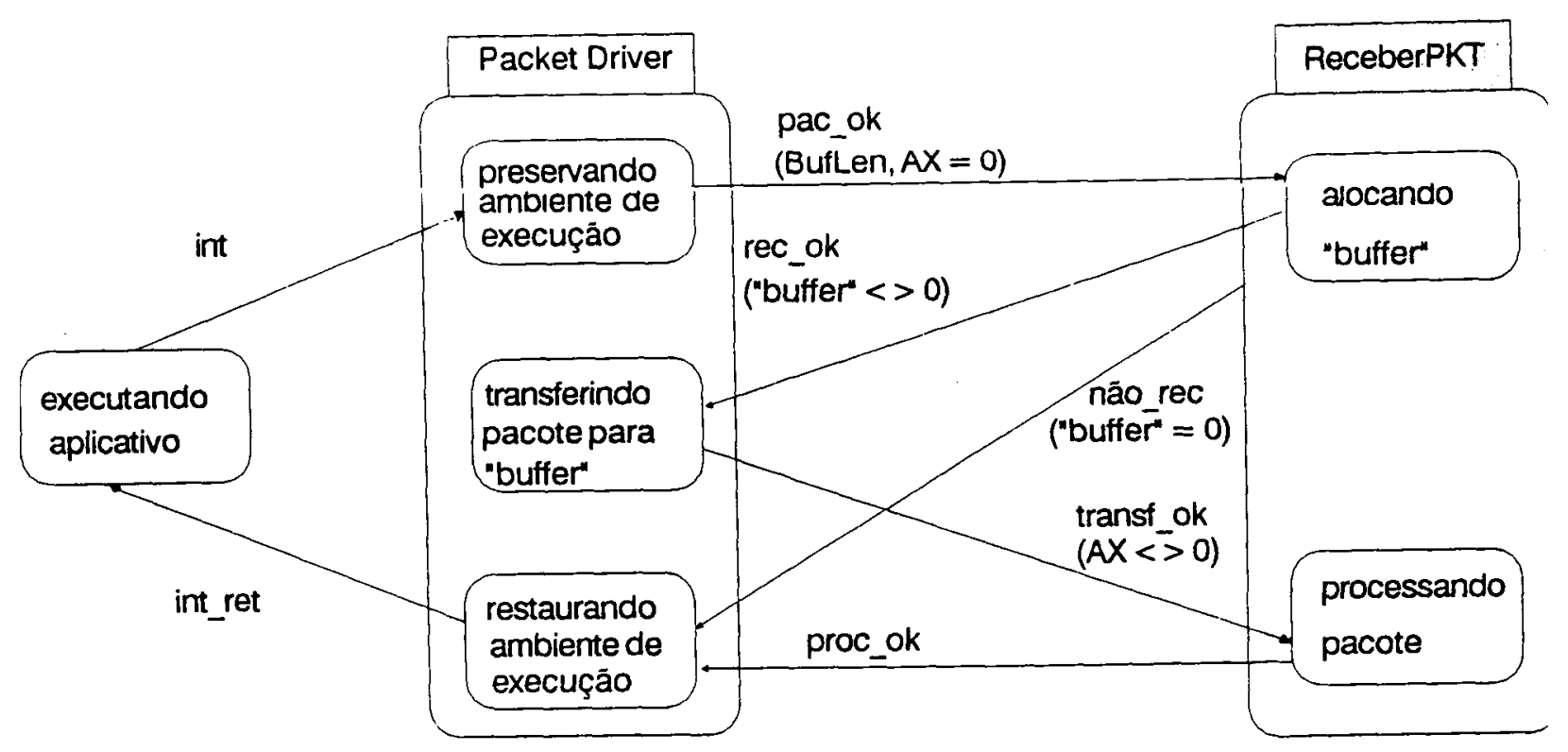

Figura 5.5: Mapas de estados do Packet Driver [TRI91]. 
Apesar de nào ser convencional, os fluxos de dados envolvidos estào indicados nesse diagrama entre parênteses. ButLen indica o tamanho necessário para o "buffer" de recepção. AX (registrador) indica para a rotina de recepçăo a primeira ( $A X=0)$ ou a segunda chamada $(A X \ll 0)$ feita pelo Packet Driver. A rotina de recepçào deve devolver o endereço do "buffer" $<0$ para que o pacote seja transferido e nào descartado.

Com a utilizaçào do Packet Driver pode-se "simular" a multiprogramaçào do servidor de correio eletrônico, pois este atende vários usuários em estações diferente, dividindo entre eles o seu tompo de processamento.

\subsection{Especificação do mecanismo de RPC}

O software no ambiente LASD foi elaborado com base no paradigma do cliente/servidor e no modelo de referência ISO/OSI. Na implementaçào do paradigma utilizou-se um mecanismo de RPC'. O modelo de referência ISO/OSI nào fornece suporte adequado ao mecanismo de RPC. Segundo Tanenbaum, em [TAN89], o mecanismo de RPC deveria ser implementado na camada de sessào.

\subsubsection{Mecanismo de RPC}

O mecanismo de RPC serviu de base para a implementação do sistema Servidor de Processamento Paralelo baseado em "transputers" (SPP), desenvolvido pelo grupo de Sistemas Distribuidos e Programação Concorrente do ICMSC. As premissas consideradas pelo mecanismo sào [TRI91]:

- mecanismo de acesso ao meio: Packet Driver;

- semântica: no máximo uma vez;

- requisições e respostas ocupam um único pacote Ethernet:

- tamanho máximo: 1514 bytes;

- chamadas alinhadas nào são permitidas;

- segue o paradigma do cliente/servidor na forma de pedido/resposta. O cliente solicita a execução de uma primitiva pelo servidor;

- chamadas bloqueantes;

- atendimento bloqueante:

- tempo de execução limitado na definição da primitiva;

- caso ocorra algum erro no servidor ou no cliente, uma mensagem é enviada ao cliente e a primitiva é abortada; 
- um pacote só accito pelo cliente ou pelo servidor se todos os campos dos cabeçalhos dos pacotes PKT o SPP (descritos abaixo) estiverem corretos.

A semântica "no máximo uma vez" é controlada pela definição de "seqüencia de requisiçăo" (no caso "zcro" ou "um"), correspondendo a variáveis associadas às primitivas que são iniciadas no cliente e no servidor. A "seqüência de requisição" no servidor é complementada após a execuçào de uma primitiva e no cliente após o recebimento da resposta. O servidor ao receber um pedido verifica se a "seqüência de requisição" para a primitiva solicitada concide com a esperada. Caso afirmativo, a primitiva é executada. C'aso contrário, o pedido é ignorado e é enviada a última resposta da primitiva, que ficou armazenada em una tabela de sessào (TSES) no servidor (figura 5.6).

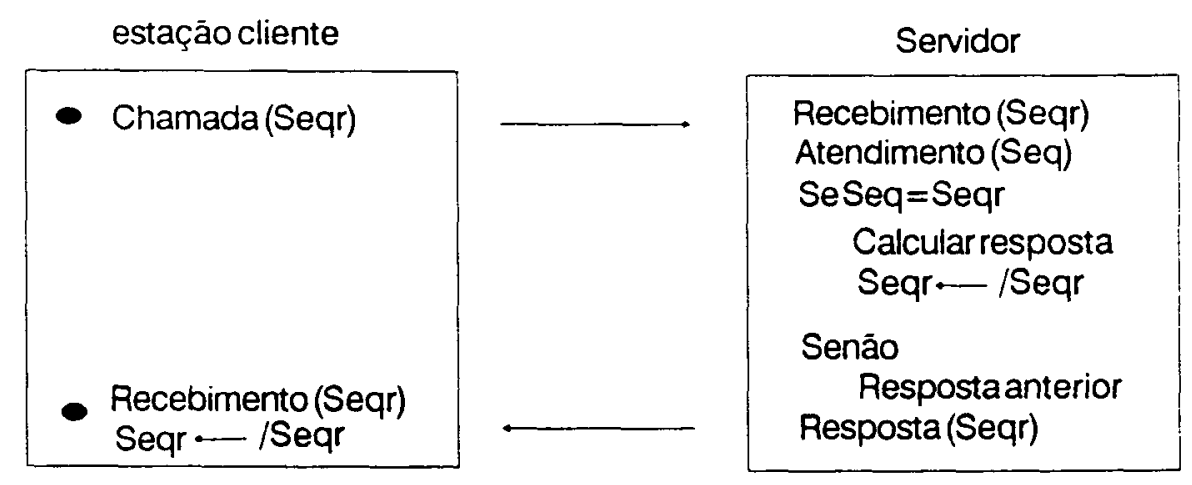

Figura 5.6: Esquema da semântica "no máximo uma vez".

$\mathrm{Na}$ elaboração desse mecanismo foram definidos dois protocolos que utilizam os seguintes pacotes [TRI91]:

1. O pacote PKT utilizado na interface com o Packet Driver (figura 5.7):

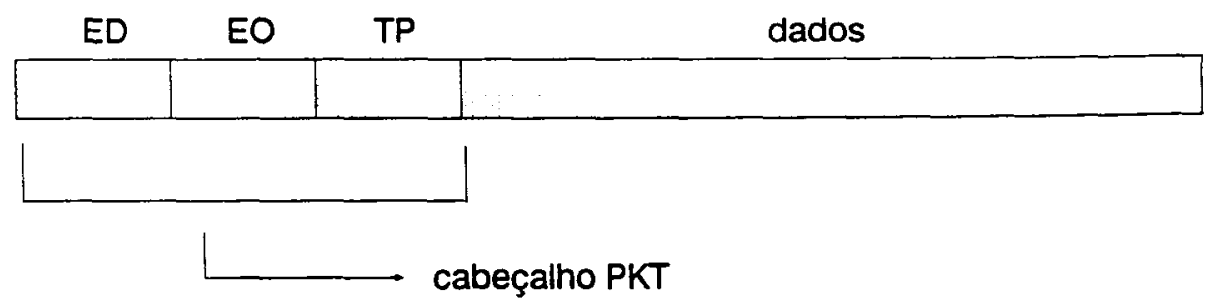

Figura 5.7: Pacote PKT [TRI91].

- ED: endereço Ethernet destino. Tamanho: 6 bytes.

- EO: endereço Ethernet origem. Tamanho: 6 bytes.

- TP: tipo do pacote. Ocupa as posições 12 e 13 do cabeçalho seguindo o padrão Blue Book Ethernet [PAC89]. Tamanho: 2 bytes.

- dados: corresponde ao pacote SPP. Tamanho máximo: 1500 bytes. 
2. O pacote SPP que dá suporte ao mecanismo RPC (figura j.s):

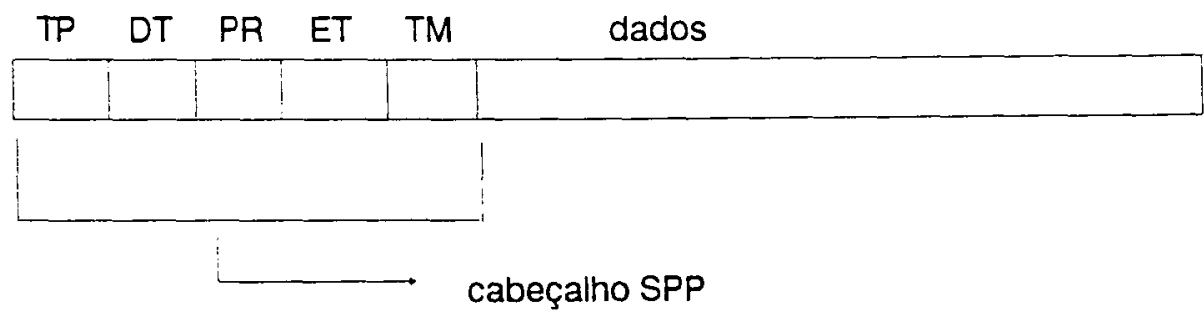

Figura 5.s: Pacote SPP [TRI91].

- TP: tipo do protocolo. O tipo do protocolo foi definido como 20 . correspondendo ao protocolo do sistema servidor de correio eletrônico. Tamanho de 1 byte. O bit mais significativo denominando:

$0 \rightarrow$ chamada de procedimento remoto

$1 \rightarrow$ resposta de procedimento remoto

- DT: destino. Indica o destino do pacote. No sentido cliente->servidor contém o identificador da sessào do usuário (ide_sessão). No sentido servidor->cliente contém o identificador do processo do usuário (ide_proc). Tamanho: 2 bytes.

- PR: identifica a primitiva a ser executada pelo servidor. Tamanho: 2 bytes.

- ET: estado retornado do servidor após a execuçào de uma primitiva. O bit mais significativo é utilizado pelo cliente e servidor para indicar a "seqüência de requisiçào" da primitiva, que deve ser controlada para a implementaçào da semântica "no máximo uma vez". Tamanho de 1 byte. As seguintes semânticas de erros do protocolo sào utilizadas:

$$
\begin{aligned}
& \text { b7 } \rightarrow \text { "seqüência de requisição" } \\
& \text { b6 } \rightarrow \text { uso futuro } \\
& \text { b5 } \rightarrow \text { erro na execução da primitiva } \\
& \text { b4 } \rightarrow \text { requisição não válida } \\
& \text { b3 } \rightarrow \text { permissão negada } \\
& \text { b2 } \rightarrow \text { sessão não existe } \\
& \text { b1 } \rightarrow \text { "time out" na execução da primitiva } \\
& \text { b0 } \rightarrow \text { uso futuro }
\end{aligned}
$$

- TM: indica o tamanho do "buffer" de dados preparado pelo "stub", contendo dados e/ou parâmetros necessários para a execução da primitiva solicitada. Tamanho: 2 bytes.

- dados: consiste dos parâmetros e dados enviados para a execução das primitivas. Tamanho máximo: 1493 bytes. 
O pacote de mais baixo nivel que circula pela rede local Ethernet é mostrado na figura 2.5. sendo utilizado o padrào DEC/INTEL/XEROX. Eliminando os campos de preâmbulo e C'RC deste pacote tem-se o pacote PKT. que em sua área de dados utiliza o pacote SPP.

\section{Estruturas de dados}

Diversas estruturas de dados foram utilizadas na implementação do mecanismo de RPC. São apresentadas a seguir as estruturas relacionadas com as operaçǒes básicas do sistema.

- Estruturas de dados no processo cliente:

Tabela de servidores - TABSERV (indexada pelo ide_servidor)

end_serv[] $\rightarrow$ endereço do servidor

ide_sessào $\rightarrow$ identificador da sessão do usuário

seq[] $\rightarrow$ "seqüência de requisição" para cada primitiva

tol ] $\rightarrow$ contador de "time out" para cada primitiva

A tabela de servidores é utilizada para controlar o envio e o recebimento de pacotes do processo servidor.

- Estruturas de dados no processo servidor:

Tabela de sessòes - TSES (indexada pelo número da sessào)

cod_usu $\rightarrow$ código de identificaçào do usuário

end_est[] $\rightarrow$ endereço da estaçăo

ide_proc $\rightarrow$ identificador do processo do usuário

seq[ ] $\rightarrow$ "seqüência de requisição" para cada primitiva

tam_res[] $\rightarrow$ tamanho máximo da resposta para cada primitiva

resp[] $\rightarrow$ ponteiros para as últimas respostas de cada primitiva

A tabela de sessões possue a mesma função que a tabela de servidores, sendo utilizada para controlar o envio e o recebimento de pacotes dos processos clientes. $O$ número da sessão é fornecido pela estação cliente, sendo que cada estação abre uma sessão diferente no servidor.

Tabela de usuários - TU (indexada pelo número da sessão)

nome_usu[] $\rightarrow$ nome do usuário

perm[ ] $\rightarrow$ permissào de execução para cada primitiva

ambiente $\rightarrow$ ambiente que o usuário está utilizando novo ou velho.

A tabela de usuários é utilizada para identificar o usuário de uma sessão. $\mathrm{O}$ ambiente utilizado por um usuário será apresentado no próximo capítulo (seção 6.4.2). 


\subsection{O uso de alias pelo despachador Sendmail}

O ambiente de um sistema SunOS pode compartilhar as bases administrativas, em particular o diretório onde sào armazenadas as correspondências ("/var/spool/mail"), através da utilizaçào do servidor de nomes NIS. Com o compartilhamento, os usuários podem ter acesso ao sistema e às suas correspondências de qualquer máquina pertencente ao sistema. Quando o ambiente nào compartilha as bases administrativas, as mensagens que chegarem ao usuário em uma determinada máquina nào serào as mesmas se estiver usando outra máquina [SUN90. SUN91a]. O uso de alias ${ }^{1}$ pelo despachador Sendmail é mostrado na figura j.9. Os elementos da figura sào descritos a seguir.

- /usr/ucb/mail $\rightarrow$ comando "mail" do sistema operacional UNIX

- mailrc $\rightarrow$ arquivo de configuração do comando "mail" do sistema UNIX. Este arquivo contém várias opçòes padrão, podendo conter alias locais, ou seja, alias que valem apenas para a área do usuário.

- usr/lib/sendmail -> despachador Sendmail.

- local/etc/aliases -> arquivo de alias locais para uma determinada máquina.

- NIS mail aliases -> correspondendo ao arquivo "/etc/aliases", arquivo de alias do servidor principal do NIS, os alias valem para todo o domínio.

- \% forward $\rightarrow$ arquivo local na área do usuário utilizado para redirecionar mensagens.

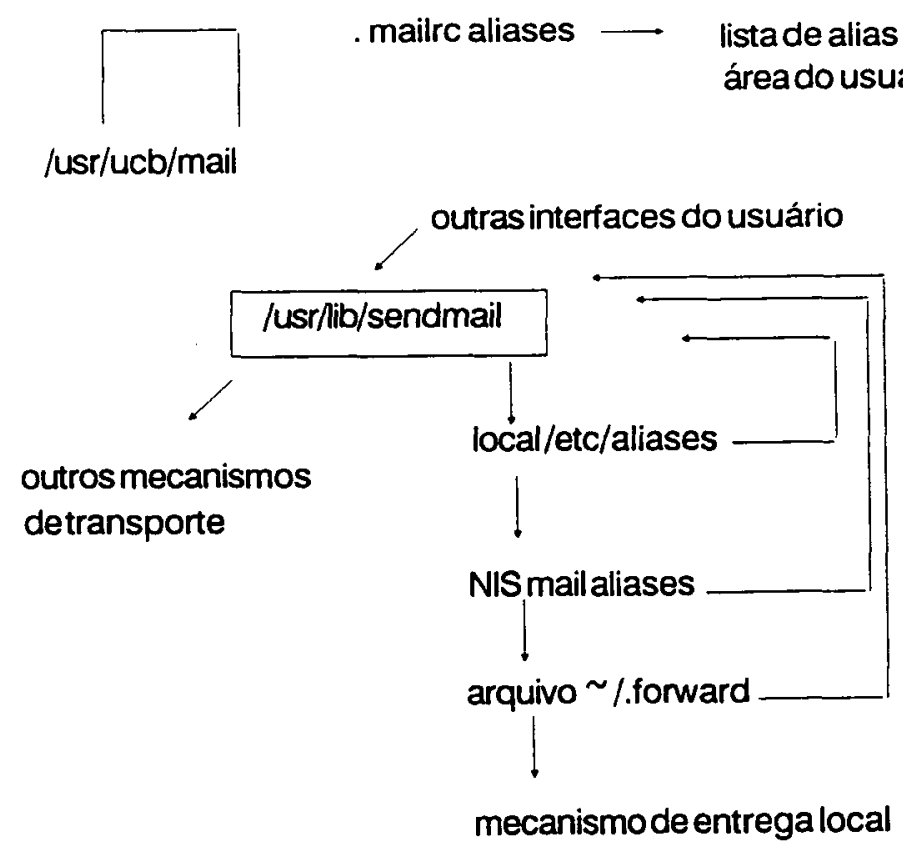

Figura 5.9: Uso de alias pelo despachador Sendmail [SUN90].

\footnotetext{
${ }^{1}$ o termo alias é utilizado nessa dissertação, sempre no singular, para designar conversão entre nomes.
} 
Uim usuário compòe uma mensagem utilizando o comando "mail" ( "/usr/ucb/mail") ou uma interface para esse comando. O arquivo ".mailrc" na área do usuário é consultado para verificar a existência de alias. A seguir o despachador Sendmail é ativado para determinar a rota que a mensagem deve percorrer para chegar ao destinatário. $O$ despachador Sendmail rerifica se existe algum alias para o destinatário nos arquivos apresentados. Se o destinatário pertencer ao domínio local a mensagem é entregue ao programa "/bin/mail" (mecanismo de entrega local) que acrescenta a mensagem na caixa postal do destinatário. C'aso contrário, o despachador Sendmail compòe o endereço do destinatário conforme necessário para enviar a mensagem ao retransmissor de domínio. A utilizaçào dos arquiros de alias deve ser feita com bastante cuidado para evitar "laços" e redirecionamentos adicionais. Os alias podem ser utilizados para:

- listas de postagem:

- redirecionar mensagens a:

- um usuário:

- um programa:

- uma máquina. etc.

O uso de alias pelo despachador Sendmail revelou-se como uma soluçăo importante para redirecionar as mensagens dos usuários do ambiente LASD para uma caixa postal no sistema SunOS.

\subsection{Considerações finais}

No cenário atual algumas das soluções para a transferência de informações é o uso de serviços de correio eletrônico e de transferência de arquivos. Entretanto, o serviço de correio eletrônico tem sido mais utilizado por causa das facilidades que a maioria dos sistemas oferece, por exemplo uma interface amigável.

Um mecanismo de acesso ao meio físico deve fornecer funções que permitam a utilização do meio por diversos sistemas - o Packet Driver é um desses mecanismos. O mecanismo de RPC usado para implementar o paradigma cliente/servidor utiliza as funções do Packet Driver. O local ideal do alias - que permite ao usuário redirecionar suas mensagens para um outro usuário - é na base de alias do NIS ("/etc/aliases"), pois o NIS faz a inversão dos endereços quando a mensagem chega ao domínio. No ICMSC, o serviço de correio eletrônico do sistema SunOS não está disponível diretamente a outros ambientes, assim um sistema que permita uma maior utilização desse serviço tem grande importância para o departamento. 


\section{Capítulo 6}

\section{Implementação do sistema}

No capítulo anterior. introduziram-se alguns tópicos relacionados com a implementação do sistema. Este capitulo apresenta as partes do sistema referentes ao nivel de implementaçào. estando organizado nas seguintes seçòes:

- Esquema de alias no sistema SunOS:

- Ligaçào do sistema SunOS ao ambiente LASD;

- Desenvolvimento dos softwares servidor e cliente.

\subsection{Introdução}

No desenvolvimento deste sistema foram utilizados alguns conceitos de Engenharia de Software, destacando-se [PRE87]:

- reusabilidade: procurou-se utilizar ao máximo os recursos disponíveis com o intuito de não desenvolver novamente softwares que estão disponíveis para uso geral e que são comprovadamente eficientes;

- modularidade: o sistema foi implementado em módulos que são integrados para satisfazer os requisitos especificados;

- portabilidade: o software foi desenvolvido o mais independente possível do sistema operacional utilizado, visando uma maior portabilidade;

- manutenabilidade: durante a elaboração do sistema, algumas decisões foram tomadas para permitir uma melhor manutenção, no decorrer do tempo de vida útil do sistema.

Foi dada atenção especial à implementação da interface com o usuário, visando fornecer uma interação bastante amigável, facilitando ao máximo a utilização do sistema. 
Como visto anterionente. o sistema servidor de correio elet rônico cstá organizado nos módulos servidor e cliente:

- o servidor fornece as seguintes funçòes: enviar mensagens do ambiente LASD para o sistema SunOS. obter do sistema SunOS as mensagens destinadas aos usuários do ambiente L L $1 S D$. distribuir as mensagens para os usuários do ambiente LASD e atender aos pediclos de execuçào das primitivas permitidas no sistema:

- o cliente oferece uma interface amigável e transparente. escondendo do usuário os detalhes de implementaçào. A interface apresenta informaçòes das mensagens recebidas e possibilita a execuçào de algumas primitivas con uma mensagem selecionada: remover. responder. copiar a mensagem na estaçào cliente. entre outras.

As etapas principais no desenvolvimento da arquitetura do sistema sào (figura 6.1 ):

1. identificasào dos usuários do ambiente LASD no sistema SunOS:

2. ligaçào do sistema SunOS ao ambiente LASD e definiçào do software executado no sistema SunOS:

3. desenvolvimento dos softwares servidor e cliente. 


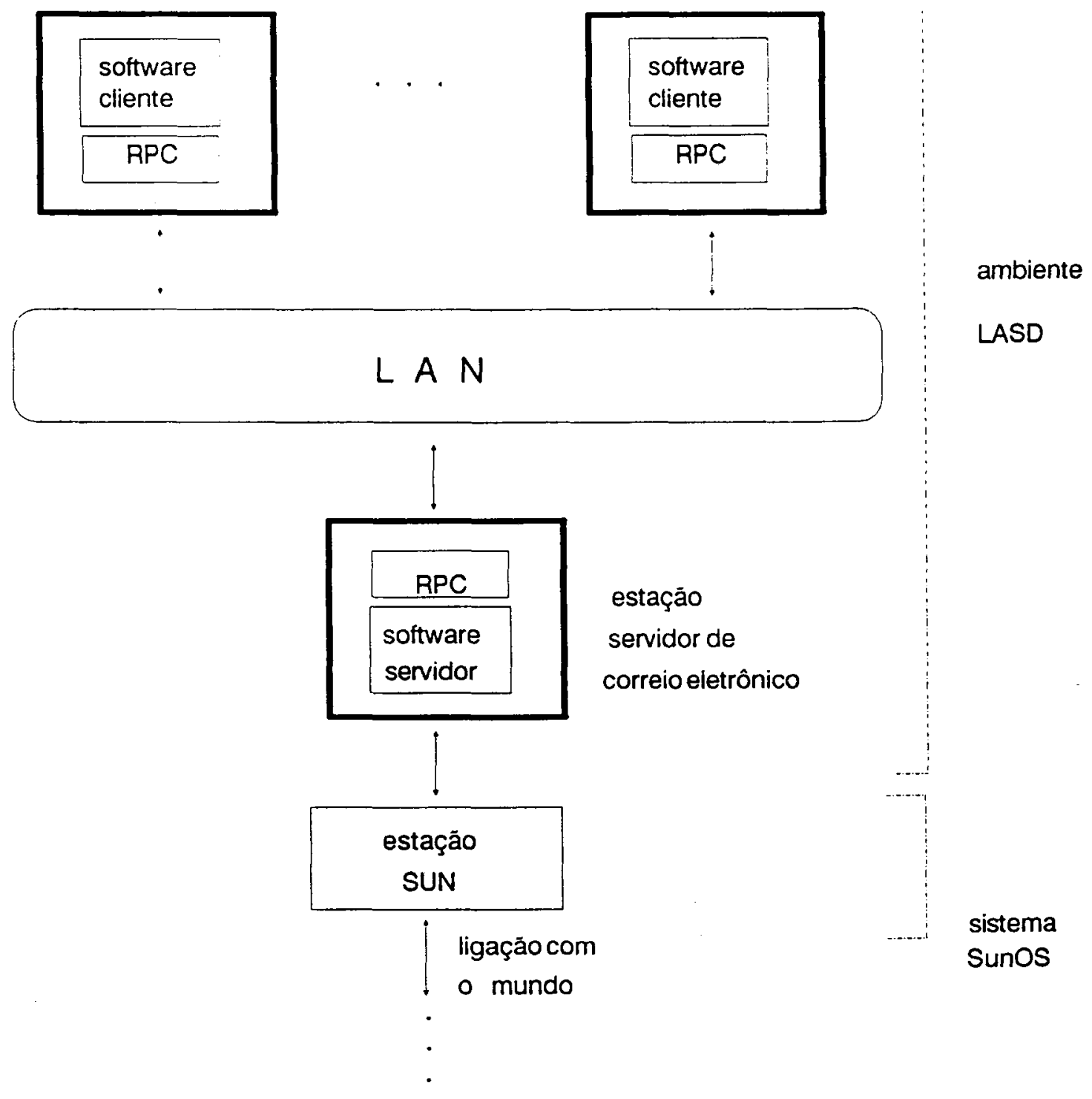

Figura 6.1: Arquitetura do sistema.

\subsection{Esquema de alias no sistema SunOS.}

Numa primeira fase do projeto foi feita a identificação dos usuários do ambiente LASD no sistema SunOS. Para efetuar a identificação é necessário definir no sistema SunOS uma tabela dos usuários do ambiente LASD. A definição da tabela é efetuada através da utilização de alias. 
O sistema Sim()S do IC $M I S C$ utiliza o servidor de nomes NIS. que permite compartilhar as bases administratiras (reja seçào j.6.4 para maiores detalhes). Para identificar os usuários do ambinme I. ASD no sistema SunOS. utiliza-se o seguinte esquema de alias:

- um usuarive licticio (lasd) é criado simulando um subdominio no dominio "icmsc";

- para cimlir usuário do ambiente LASD acrescenta-se um alias no arquivo "/etc/aliancs" la máquina "mailbox server". permitindo que as mensagens endereçadia us usuarios do ambiente LASD sejam redirecionadas para o usuário fictício crialu. I estrutura dos alias corresponde a:

nome-do-usuário: lasd

Para compluill " esquema de alias. é executado o comando "newaliases" do sistema SunOS. Este cumando atualiza as bases de dados de acesso aleatório "/etc/aliases.dir" e "/etc/aliases/ pà". que contêm informaçòes lidas pelo despachador Sendmail na utilização de alias.

Através derser ciquema de alias. todas as mensagens clestinadas aos usuários do ambiente LASD siu almazenadas em uma única caixa postal no sistema SunOS, denominada "/var/spool/mail/lasd". O esquema de alias definido possibilita uma maneira simples e eficiente de efetnar um redirecionamento das mensagens, simulando a tabela pretendida.

\subsection{Ligação do sistema SunOS ao ambiente LASD}

O ambiento I.ISD e o sistema SunOS sào interligados pela estaçào servidor de correio eletrônico. Para efetuar a transferência de dados, utiliza-se o protocolo TCP/IP, pois existem várias implementaçòes desse protocolo para $\mathrm{PC}$ 's, de fácil utilizaçào e comprovadamente eficientes - conceito de reusabilidade. Duas implementaçòes de domínio público do protocolo TCP/IP sào bem difundidas para PC's, o chamado KA9Q e o NCSA (National Center for Supcrcomputing Applications):

- o KA9Q (TCP/IP) Internet Packet, desenvolvido para redes de comutação por pacotes por rádio amador, também pode ser usado por outras redes de comutação por pacotes. Através do programa NET, o KA9Q oferece os protocolos IP, ICMP, TCP e I'DP. e implementa os protocolos de comunicaçào FTP, TELNET e SMTP [KAR91]:

- o TCP/IP NCSA para IBM PC, oferece acesso interativo e não interativo de um IBM PC' ou compatível. a hospedeiros Telnet sobre redes TCP/IP. Os hospedeiros Telnet sào computadores que possuem um endereço IP conhecido pela configuração instalada no PC. NCSA Telnet é uma implementação padrão do DARPA Telnet com características adicionais que melhoram o processamento local do PC [NCS91]. 
Por fornecer 11 un acesso nào interativo. a implementaçào do protocolo FTP do NCSA foi escolhida (versio 2.3). Alguns outros fatores que contribuem para a utilização do protocolo FTP do X('S.l sào:

- o sistema SinoSi utiliza o conjunto de protocolos TCP/IP:

- a decisào de efet uar a transferência de dados parte do ambiente LASD, possibilitando uma maior "independência” entre o ambiente LASD e o sistema SunOS:

- a existência de 1 m "time out" no protocolo FTP, que especifica quanto tempo deve ser esperado para estabelecer a conexào com o hospedeiro. O "time out" permite a utilizaçà du sistema servidor de correio eletrônico, mesmo que o sistema SunOS nào esteja funcionando:

- a grande acrilaçào desse protocolo, apresentando um ambiente maduro e estável.

Para completar a parte do sistema que executa no sistema SunOS. é definida a estrutura do arquivo transferido do ambiente LASD para o sistema SunOS. O arquivo contém as mensagens enviadas pelos usuários do ambiente LASD, sendo "desmembrado" no sistema SunOS, ou seja. as mensagens são separadas e enviadas a seus destinatários utilizando o sistema de correio cletrônico do sistema SunOS.

Os usuários do ambiente LASD utilizam a interface do sistema para compor suas mensagens (figura 6.2), seguindo o padrão RFC 822 . As mensagens são enviadas para a máquina servidor de correio eletrônico que as armazena num arquivo denominado "entrada" (figura 6.3). que por sua vez será transferido ao sistema SunOS.

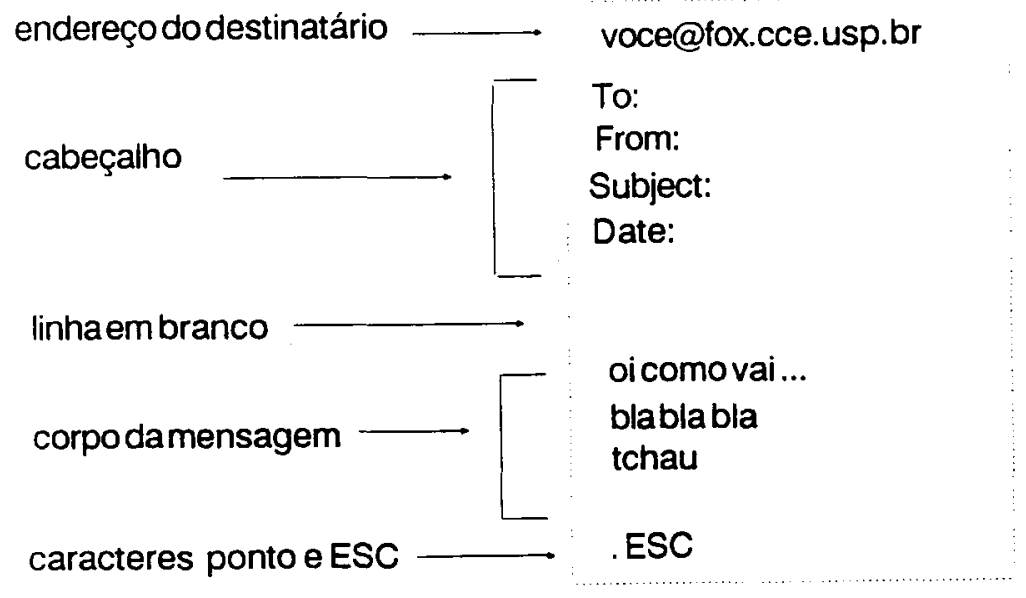

Figura 6.2: Estrutura de uma mensagem. 
mensagem 1

mensagem 2

Figura 6.3: Estrutura do arquivo "entrada".

A primeira e a última linhas são utilizadas no sistema SunOS, respectivamente, para identificar o destinatário e para indicar o final de uma mensagem. O caracter ponto é requisitado pelo sistema de correio eletrônico do sistema SunOS para indicar que a mensagem a ser enviada chegou ao fim, e o caracter ESC é utilizado pelo software desenvolvido como um identificador de fim de mensagem. Quando o arquivo "entrada" é transferido, um software ("lamail") executando em "background" no sistema SunOS analisa o arquivo e o "desmembra", ou seja, separa as mensagens analisando o arquivo "entrada" até encontrar o caracter ESC. A mensagem analisada é gravada em um arquivo auxiliar. Com o arquivo auxiliar e o endereço do destinatário (obtido na primeira linha da mensagem), é utilizado o comando "mail" do sistema operacional UNIX para enviar a mensagem. O comando "mail" ativa o despachador Sendmail que permite redirecionar a mensagem para seu destinatário.

\subsection{Desenvolvimento dos softwares servidor e clien- te.}

Algumas considerações sobre o sistema desenvolvido:

- Com o objetivo de se obter uma maior portabilidade do sistema, utilizou-se a linguagem $\mathrm{C}$, sendo que foram codificados em linguagem montadora módulos de interface entre os programas $\mathrm{C}$ e as funções disponíveis no Packet Driver;

- O sistema operacional utilizado foi o DOS. O sistema desenvolvido visa atender o maior número de estações clientes possíveis, e no ambiente LASD a grande maioria dos equipamento utiliza esse sistema operacional; 
- O editor W kexto utilizado na interface foi o Norton. por sua fácil utilizaçào e por ser bastante conhecido pelos usuários do ambiente LASD:

- Para a communicaçào entre os módulos cliente e servidor foi utilizado o paradigma cliente/scrvidor co mecanismo RPC apresentado na seçào 5.4.1. A utilização desse mecanismo loi decorrente dos seguintes fatores:

- a possibilidade de "simular" a multiprogramação no sistema operacional DOS;

- o mucanismo permite à estação servidor de correjo eletrônico suspender o atendimcnto das estaçòes clientes para executar outras funçòes. ou seja, a estacio servidor de correio eletrônico nào precisa ficar executando um softwarc permanentemente para receber e enviar pacotes às estações clientes.

Durante a utilizaçào do mecanismo de RPC. verificou-se uma restriçào com relação à transferência de aruuiros. Assim, implementou-se uma "extensão" para esse mecanismo, correspondendo a um módulo que utiliza o mecanismo de RPC' existente.

\subsection{1 "Extensiio" do mecanismo de RPC}

Para o envio c recebimento de arquivos, o sistema de RPC inicialmente utilizado apresentava restriçio quanto ao tamanho máximo de um arquivo, 1493 bytes. $\mathrm{O}$ tamanho máximo do pacote transmitido pelo Packet Driver é 1514 [CLA89]. Os primeiros 14 bytes sào utilizados pelo cabeçalho do protocolo $\mathrm{PKT}$, os 7 próximos bytes são utilizados pelo cabeçalho do protocolo SPP. Restando 1493 bytes para o envio de dados (figura 6.4).

$0 \quad 13 \quad 20$

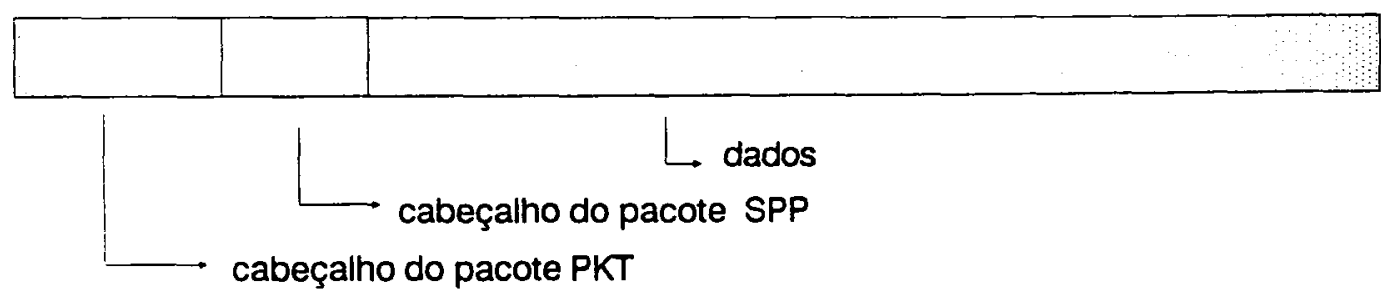

Figura 6.4: Restrição do mecanismo de RPC.

Como a maioria das primitivas do sistema servidor de correio eletrônico utiliza o envio e o recebimento de arquivos são, então, definidas primitivas básicas que efetuam tais funções. Com esta finalidade, tem-se um programa teste, que apresenta a seguinte correspondência das primitivas no cliente e no servidor (figura 6.5): 
Enviar_arquivo
Receber_arquivo

No cliente
Receber_arquivo

Enviar_arquivo

No servidor

Figura 6.5: Relação das primitivas.

Considera-se ma estrutura de dados (TABELA) no cliente e no servidor para dividir um arquivo em pacotes e analisar o número dos pacotes esperado e enviado. Se os números dos pacotes diferern. a primitiva é abortada e uma mensagem de erro é enviada ao cliente.

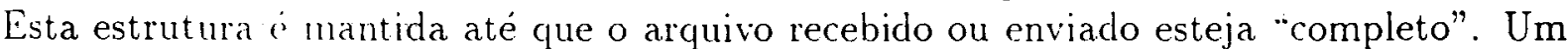
arquivo é clenominado "completo" quando o número total de pacotes a receber ou a enviar for igual a zero.

A estrutura de dados TABELA no cliente possue os seguintes campos:

nome[ ] $\rightarrow$ nome do arquivo.

tam_arq $\rightarrow$ tamanho do arquivo.

totpac $\rightarrow$ número total de pacotes a receber ou a enviar.

pacote $\rightarrow>$ numero do pacote recebido ou enviado.

A estrutura de dados TABELA no servidor está associada a cada sessão, sendo acrescentados os seguintes campos:

posiçào -> corresponde à posiçào do último caracter do arquivo que foi enviado ao cliente. Possibilita que o servidor identifique o próximo caracter do arquivo a enviar.

operação $\rightarrow$ última operação efetuada (Enviar_arquivo ou Receber_arquivo). Com este campo e o campo "totpac" é verificada a existência de "arquivos incompletos".

$\mathrm{Na}$ transferência de arquivos pode ocorrer que partes de arquivos fiquem no disco da estação servidor de corrreio eletrônico e/ou no disco das estações clientes ("arquivos incompletos"), decorrente de algum problema na transmissão dos dados. Esses arquivos devem ser removidos, pois caso contrário o disco das estações podem ficar cheios de "lixo". Diante dessa possibilidade é definido um mecanismo de verificação do disco, para evitar que tais arquivos sejam guardados desnecessariamente.

Se acontecer algum problema no cliente e/ou no servidor e a primitiva sendo executada for Receber_arquivo, esta será abortada e deixará no disco da estação servidor um "arquivo 
incompleto". O módulo Verifica_disco verifica para a sessào aberta se o campo "totpac" está zerado. caso negativo. o arquivo identificado pelo rampo "nome" é removido do disco da estaşa servidor. O módulo Verifica_disco é executado no software servidor nas seguintes situaçoes:

- quando o usuário inicia a utilizaçào do servidor. para identificar se o usuário anterior da sessào nào deixou "arquivos incompletos" no servidor. Se uma estação "travar" (por exemplo por problemas de hardware) e o usuário desligar a estaçào sem ter encerrado a sessào no servidor e. portanto. como nào ocorreu uma verificação de "arquivos incompletos". será necessário efetuar a verificação quando a sessão for novamente utilizada:

- na recepcào de um arquivo do cliente. se o nome do arquivo recebido difere do arquito esperado (identificado pelo campo "nome"):

- quando um código de crro é enviado ao cliente, pois este pode ser decorrente de algum problema que cause a existência de um "arquivo incompleto":

- quando o usuário encerra a sessào com o servidor.

No software cliente. a verificaçào de "arquivos incompletos" também é efetuada pelo módulo Verifica_disco nas seguintes situaçòes:

- na recepçào de um arquivo do servidor, se o nome do arquivo recebido difere do arquivo esperado (identificado pelo campo "nome");

- quando uma mensagem de erro é enviada ao cliente. pois quando isso ocorre a primitiva é abortada;

- quando o usuário encerra a sessào com o servidor.

\subsubsection{O software servidor}

$\mathrm{Na}$ estação servidor de correio eletrônico, é mantido um arquivo de usuários do sistema (SUPER.H) e uma caixa postal para cada usuário em um subdiretório MAILBOX. As mensagens recebidas por um usuário são mantidas em sua caixa postal na estação servidor de correio eletrônico, sendo enviadas à estação cliente somente quando um usuário as requisita através da interface. A caixa postal segue a estrutura mostrada na figura $6.6 \mathrm{a} \mathrm{e}$ os subdiretórios novo e velho seguem a estrutura mostrada na figura $6.6 \mathrm{~b}$.

caixa postal $=$ subdiretório contendo os subdiretórios novo e velho, e um arquivo de senha;

subdiretório novo: subdiretório contendo as mensagens lidas e não lidas pelo usuário - ambiente novo;

subdiretório velho: subdiretório contendo as mensagens lidas que o usuário deseja guardar - ambiente velho;

password.dat: arquivo contendo a senha do usuário, criptografada. 


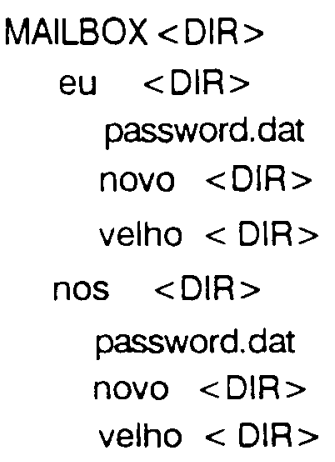

a)
b) novo.dat velho.dat
B1311092.952
B1411093.015

Figura 6.6: Estrutura: a) do subdiretório MAILBOX b) dos subdiretórios novo e velho.

O nome da mensagem no disco da estaçào servidor de corrcio eletrônico possue relação lireta com o dia e a hora clo sistema operacional em que a mensagem foi armazenada, permitindo que as mensagens sejam armazenadas com nomes diferentes. Por exemplo, a mensagem B1311092.952 foi armazenada na caira postal do usuário no dia 13 de novembro (mês 11) ás 9:29:52. Os nomes dos arquivos iniciam com o caracter "B". porque no sistema operacional DOS os nomes de arquivos nào podem iniciar com números. Os arquivos "novo.dat" e "relho.dat" sào denominados arquivos de cabeçalhos. pois contêm alguns campos do "cabeçalho padrão" das mensagens. Os arquivos de cabeçalhos sào atualizados sempre que uma mensagem for recebida. removida. movida ou consultada. Quatro linhas identificam uma mensagem nos arquivos de cabeçalho:

- nome da mensagem no disco da estaçào servidor, relacionado com o dia e a hora em que ela foi armazenada:

- un caracter que indica se a mensagem foi consultada pelo usuário (caracter branco) ou nào (caracter "N"), e o campo "Date" da mensagem. O caracter "N" é utilizado pelo software que gera a interface com o usuário:

- campo "From" da mensagem:

- campo "Subject" da mensagem.

Exemplo de um arquivo de cabeçalho:

B1312092.345

N Date: Mon. 13 Dec 91 14:37:50 EST

From: smacalde@icmsc.usp.ansp.br

Subject:

B1312221.430

Date: Tue, 13 Dec 91 20:45:23 EST

From: rorib@icmsc.usp.ansp.br

Subject: eueueueueueueueuu 
O arquivo de usuários contém uma lista dos usuários do sistema e identifica quais deles sào "super-usuários" (indicado pelo caracter "S"). Os "super-usuários" têm a função de gerenciar o sistema. isto $\dot{e}$ inserir e remover usuários ou "super-usuários". O sistema sempre requisita a existência de um "super-usuário". pois este nào pode ficar sem um gerente. $\mathrm{O}$ software servidor executa as seguintes funçōes básicas:

- enviar mensagens do ambiente LASD para o sistema SunOS, utilizando o protocolo FTP (figura 6.T);

- obter do sistema SunOS as mensagens destinadas aos usuários do ambiente LASD, utilizando o esquema de alias (seçào 6.2) e o protocolo FTP (figura 6.8);

- distribuir as mensagens para os usuários do ambiente LASD. ou seja, armazená-las nas correspondentes caitas postais dos destinatários e atualizar o arquivo "novo.dat":

- atender os pedidos de execuçào de primitivas.

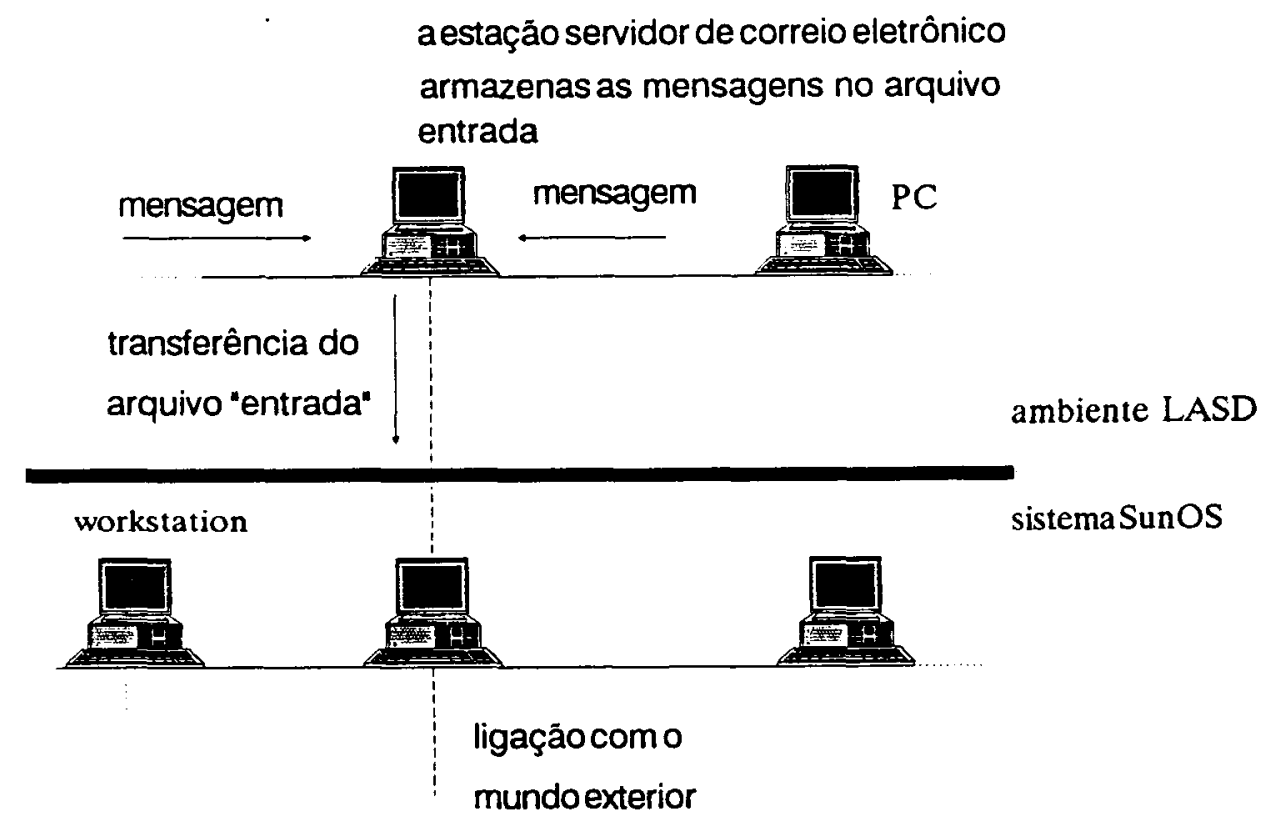

Figura 6.7: Envio. 


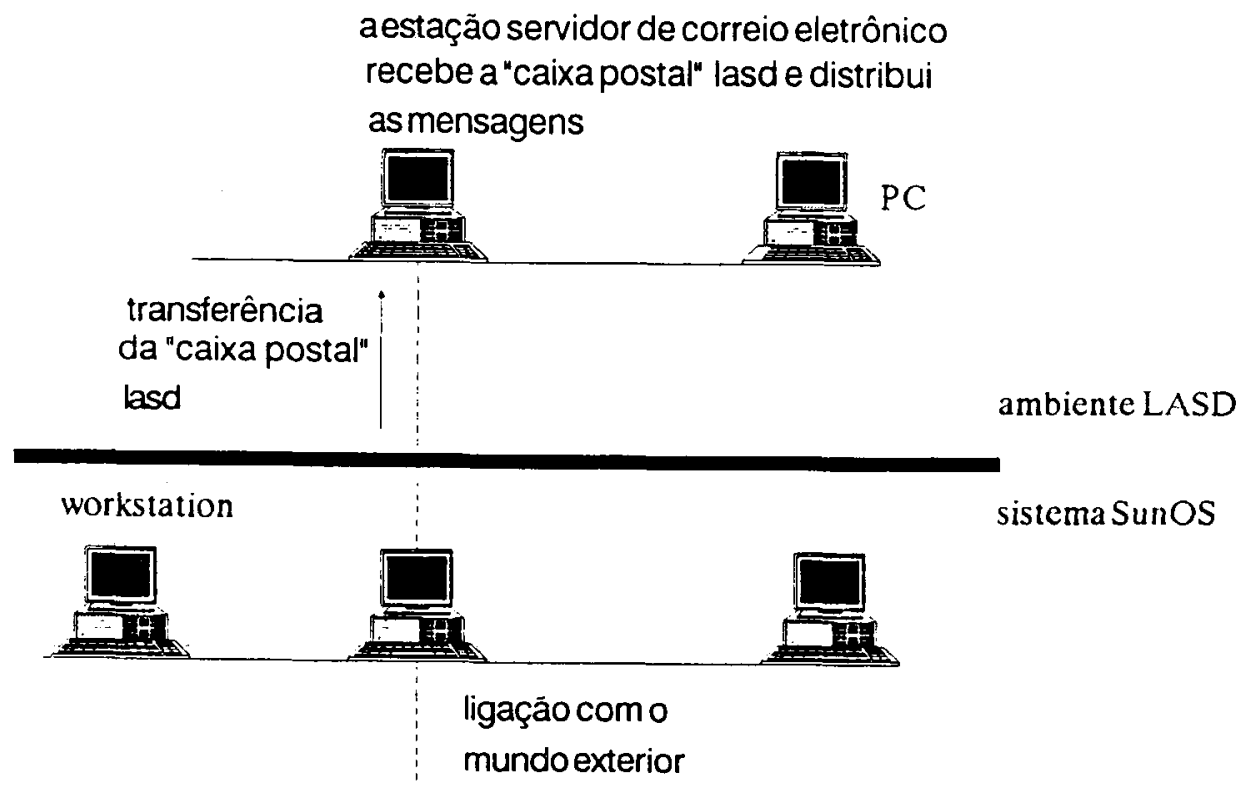

Figura 6.8: Recebimento.

\section{Atender os pedidos de execução de primitivas}

O software servidor segue uma estrutura em camadas. A figura 6.9 apresenta uma possível correlação do software servidor com o modelo de referência ISO/OSI.

\begin{tabular}{|c|c|}
\hline camadas 6 e 7 & $\begin{array}{l}\text { implementação das primitivas } \\
\text { ecomunicação com o siste- } \\
\text { maSunos }\end{array}$ \\
\hline \multirow[b]{2}{*}{ camada 5} & "stub" do servidor \\
\hline & RPC doservidor \\
\hline & Transporte do pacote \\
\hline camadas 3 e 4 & $\begin{array}{l}\text { RCVS: recebe e armazena } \\
\text { pacotes }\end{array}$ \\
\hline camada2 & PACKS: tem acesso ao meio \\
\hline camada 1 & Ethernet \\
\hline
\end{tabular}

Figura 6.9: Estrutura em camadas do software servidor. 
O meio físico utilizado é Ethernet [MET76. SHOS2]. O Packet Driver implementa a camada 2. ficando residente em memória. O Packet Driver é invocado ria interrupção (int) de software na regiào $0 \times 60$ a 0x80 (hexadecimal). sendo necessário fornecer através de parâmetro o referido número da interrupçào.

$\mathrm{O}$ acesso às funçòes do Packet Driver é feito através do módulo PACKS.C. O módulo de software RCVS.C' (ReCeiVeServidor) faz parte da próxima camada e tem como função receber e armazenar pacotes, seguindo o protocolo PKT [TRI91]. O serviço de transporte do protocolo SPP é efetuado na camada de software TRPS.C: ela efetua a transaçã̃o entre pacotes, seguindo o protocolo PKT e SPP, sendo composta de duas rotinas básicas, Receber_SPP e Transmitir_SPP (figura 6.10):

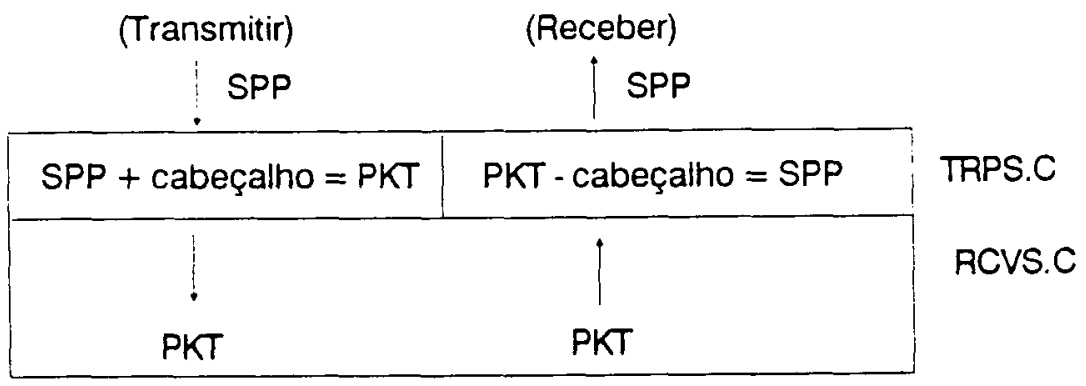

Figura 6.10: Transação entre os protocolos PKT e SPP [TRI91].

O tratamento das chamadas a procedimentos remotos está no nível da camada de sessão, conforme sugerido por Tanenbaum em [TAN89]. A "extensão" do mecanismo de RPC está na camada de RPC, no módulo RPCSERV.C. A implementação das primitivas e a interconexão com o sistema SunOS correspondem às camadas de apresentação e aplicação. As primitivas implementadas estão na camada "stub", no módulo STUBSERV.C, e correspondem a:

- Delete: remover uma mensagem. Essa primitiva remove uma mensagem da caixa postal do usuário, atualizando o arquivo "novo.dat" ou "velho.dat", dependendo do ambiente utilizado;

- Move: mover uma mensagem do ambiente novo para o ambiente velho ou vice-versa, atualizando os arquivos de cabeçalhos;

- Send: enviar uma mensagem. A primeira linha da mensagem contém os nomes dos destinatários, separados por espaços. Após o recebimento da mensagem, é efetuada uma análise na primeira linha, separando-se os destinatários pertencentes ou não ao ambiente LASD. No primeiro caso, uma cópia da mensagem é armazenada diretamente na caixa postal do destinatário. No segundo caso, uma cópia da mensagem é acrescentada ao arquivo "entrada" para posterior redirecionamento pelo despachador Sendmail;

- View: consultar uma mensagem;

- Copy: copiar uma mensagem na estação cliente; 
- Exit: terminar a sessào com o servidor:

- Old ou New: mudar de ambiente. sendo enviado o arquiro de cabeçalhos do ambiente complementar. Se o usuário estiver utilizando o ambiente novo é enviado o arquivo "velho.dat" e vice-versa (a primitiva Old é utilizada no ambiente novo e a primitiva New no ambiente velho):

- Login: iniciar a utilizaçào do sistema. É verificado se a senha fornecida coincide com a senha (criptografada) armazenada no arquivo "password.dat". Caso afirmativo, uma mensagem indicando que a sessão está aberta é enviada ao cliente. permitindo que ele solicite o envio do arquivo "novo.dat". Esta primitiva é composta por duas primitivas: Login e Loga. A primitiva Login verifica a senha do usuário e abre a sessào. enquanto que a primitiva Loga permite o envio do arquivo "novo.dat";

- Forward: redirecionar uma cópia da mensagem para um usuário pertencente ou nào ao ambiente L.ASD:

- Print: imprimir uma mensagem na estação cliente. Antes de solicitar o envio da mensagem pelo servidor é verificada a disponibilidade da impressora na estação;

- pAssword: mudar a senha do usuário:

- sUper: funçòes reservadas aos "super-usuários":

- Inserir um usuário;

- Remover um usuário;

- Consultar lista de usuários:

- Inserir o atributo de "super-usuário";

- Remover o atributo de "super-usuário".

A camada "stub" gerencia a execuçào das quatro funções exercidas pelo software servidor (módulo STUBSERV.C):

1. tratar pacotes a nivel do protocolo SPP;

2. enviar o arquivo "entrada" ao sistema SunOS;

3. receber o arquivo "/var/spool/mail/lasd" ("carta") do sistema SunOS contendo as mensagens destinadas aos usuários do ambiente LASD;

4. "desmembrar" o arquivo "carta", ou seja, armazenar çada mensagem na caixa postal do respectivo destinatário.

Na funçào 1 , o servidor recebe pacotes referentes à solicitação do cliente, verifica e retira os cabeçalhos (PKT e SPP). Se estes estiverem corretos, identifica e encaminha os dados para o processo que irá executar a primitiva solicitada. As funções 2 e 3 são efetuadas utilizando-se o protocolo FTP do NCSA. É utilizada a função de entrada $-f$ do protocolo FTP para fornecer um acesso não interativo via um arquivo. $O$ arquivo deve conter os seguintes comandos do protocolo FTP: 
- nome e senha do ambiente LASD no sistema SunOS:

- send entrada. para enriar o arquivo "entrada" contendo as mensagens a serem redirecionadas pelo despachador Sendmail do sistema SunOS:

- get / var/spool/mail/lasd carta. para obter o arquivo "carta" contendo as mensagens destinadas aos usuários do ambiente LASD.

Como o sistema operacional DOS foi utilizado, as funçòes do software servidor são executadas por partes. Em intervalos de 15 minutos o sistema pára a execução da função 1 e realiza as funçoes 2.3 e 4 . O diagrama de estados da figura 6.11 apresenta um esquema das funçòes executadas. tendo como estado inicial "inicia time" e estado final "fim execuçào". As variáveis "time" e "timel" são variáveis auxiliares que verificaram se chegou o momento de efetuar a interconexào com o sistema SunOS. A variável "time 2" armazena o tempo que deve ser esperado para efetuar a interconexào com o sistema SunOS.

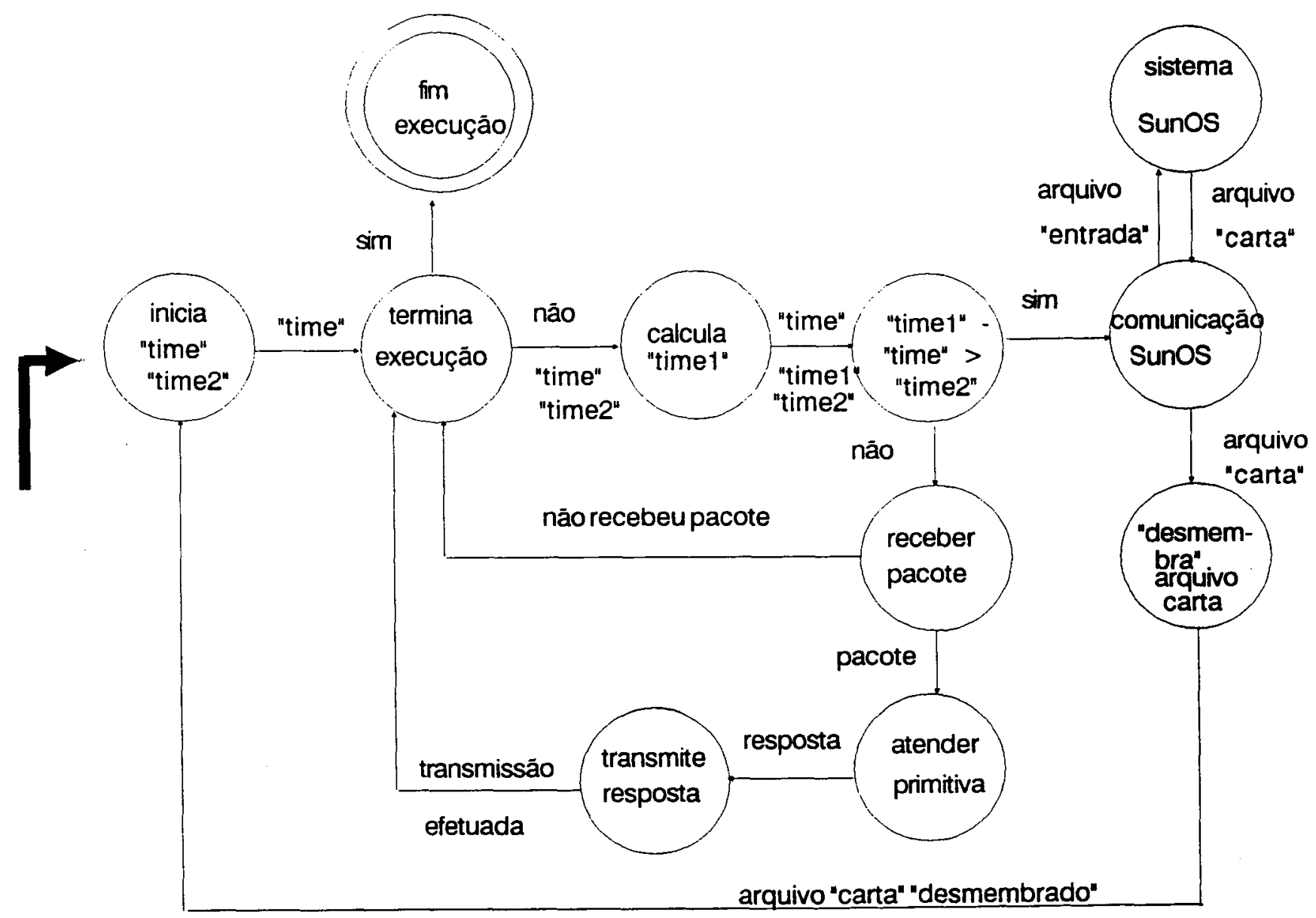

Figura 6.11: Esquema da execução das funções da camada RPC. 
Se ocorrer algum problema no sistema SunOS e nào for possivel efetuar a interconexão, o protocolo FTP suspende a tentativa de interconexào depois de decorrido o "time out" de acesso ao hospedeiro. O tempo para efetuar uma nova tentativa de interconexăo passa ser de 1 hora, esperando que o sistema SunOS volte a funcionar nesse intervalo de tempo. Após conseguir restabelecer a interconexào com o sistema SunOS. o tempo de acesso volta a ser de 15 minutos (esses valores podem ser facilmente alterados).

Durante o periodo de implementação do sistema, verificou-se que algumas variáveis podem se alterar com uma certa freqüência. Visando facilitar a manutençào do sistema, foi definido un arquivo de configuraçào da estaçào servidor de correio eletrônico (SERCONF.FIG) que contém essas variáveis. A primeira variável indica como um usuário do ambiente LASD é identificado no sistema SunOS; a identificação é realizada concatenando-se o nome do usuário com a variável. A segunda variável indica o nome da estaçào no sistema SunOS a que a estaçào servidor de correio eletrônico conectase através do protocolo FTP. Na atual configuraçào do sistema o arquivo SERCONF.FIG contém as variáveis:

Qicmsc.usp.br ioruba

\subsubsection{O software das estações clientes}

O software das estações clientes também segue uma estrutura em camadas. Uma possível correlaçào com o modelo de referência ISO/OSI é apresentada na figura 6.12.

\begin{tabular}{|l|l|}
\cline { 2 - 2 } camadas 6 e 7 & Interface com o usuário \\
\cline { 2 - 2 } & 'stub" da estação \\
\cline { 2 - 2 } camada 5 & RPC da estaçăo \\
\cline { 2 - 2 } & Transporte do pacote \\
\hline camadas 3 e 4 & $\begin{array}{l}\text { RCVE: recebe e armazena } \\
\text { pacotes }\end{array}$ \\
\hline camada 2 & PACKE: tem acesso ao meio \\
\hline camada 1 & Ethernet \\
\hline
\end{tabular}

Figura 6.12: Estrutura em camadas do software cliente.

A camada 1 representa o meio físico, o meio Ethernet. O Packet Driver implementa a camada 2. As funções relacionadas com as camadas de rede e de transporte corres- 
pondem aos módulos TRPE.C e RCVE.C. O tratamento das chamadas a procedimentos remotos está no nivel da camada de sessào. A "extensão" do mecanismo de RPC está no módulo RPCEST.C'. Nas camadas superiores, de apresentaçào e aplicaçào, encaixam-se a implementação das primitivas e a interface com o usuário.

Em cada estaçào deve haver um arquivo de configuraçào, denominado ESTCONF.FIG. Este arquivo contém duas variáveis: a primeira é a identificaçào da sessào a ser aberta no servidor e a segunda. como um usuário do ambiente LASD é identificado no sistema SunOS. A identificaçào da sessào deve apresentar o seguinte formato:

palatra_sessio: número da sessão com dois digitos decimais.

Va atual configuraçào do sistema uma estaçăo cliente contém o seguinte arquivo ESTCONF.FIG:

Sessào: 02

Qิicmsc.usp.br

\section{A interface com o usuário}

O propósito de uma interface com o usuário é facilitar a comunicação usuário-computador. A comunicação envolve tanto hardware quanto software, particularmente a semântica das aplicaçōes num diálogo. Esse diálogo esconde a estrutura dos equipamentos de entrada e saída. do sistema operacional, de redes e aplicações, e permite ao usuário permutar nas aplicaçōes fornecidas pelo sistema rapidamente [FIS89, MAR91].

A interface com o usuário é um ponto importante em um sistema, pois ela deve fornecer subsídios suficientes para o usuário utilizar o sistema. A interface com o usuário foi elaborada visando fornecer as informaçòes básicas para a identificação de uma mensagem de forma amigável e de fácil compreensão. Segundo Myers, em [MYE89], o único modo confiável de elaborar uma interface de qualidade é através da utilização de protótipos, que são modificados com base nos comentários feitos pelos possíveis usuários do sistema. Com o objetivo de desenvolver uma interface confiável utilizou-se um protótipo, que foi sucessivamente modificado a fim de atender às necessidades dos usuários.

Para se ter acesso ao servidor, são requisitados o nome e a senha do usuário, sendo o limite destes de 8 caracteres. O número máximo de tentativas de acesso é limitado em 5 , na sexta tentativa o sistema é desativado. Se o acesso ao servidor for efetivado, é enviado o arquivo "novo.dat" que possibilita a elaboração de uma tela de apresentação (figura 6.13) contendo linhas de cabeçalho. As linhas de cabeçalho contêm algumas informações do "cabeçalho padrăo" das mensagens (veja seção 4.3.3 para maiores detalhes), que possibilitam identificar unicamente uma mensagem. O número máximo de linhas de cabeçalho por tela é quatorze (limitado pelo tamanho do video), sendo oferecidas as funções de tela "PgUp", "PgDn" e as setas para baixo e para cima. Após as linhas de cabeçalho, são apresentadas as primitivas e funções de tela que podem ser executadas. As linhas de cabeçalho seguem a estrutura apresentada na figura 6.14 . 


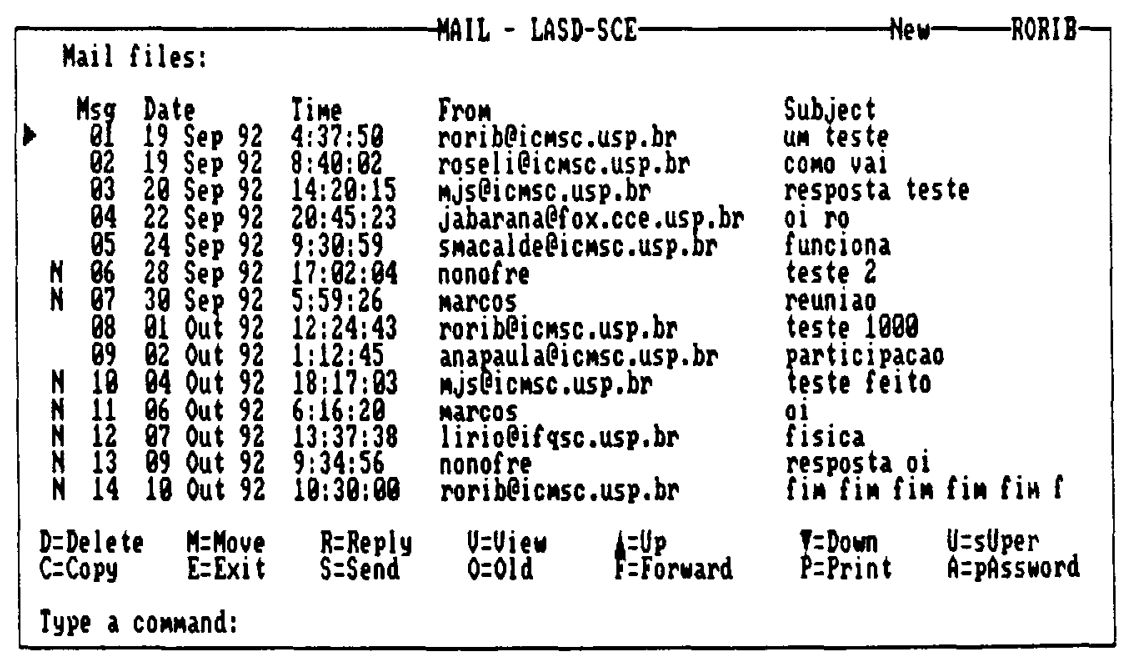

Figura 6.13: Tela de apresentaçào.

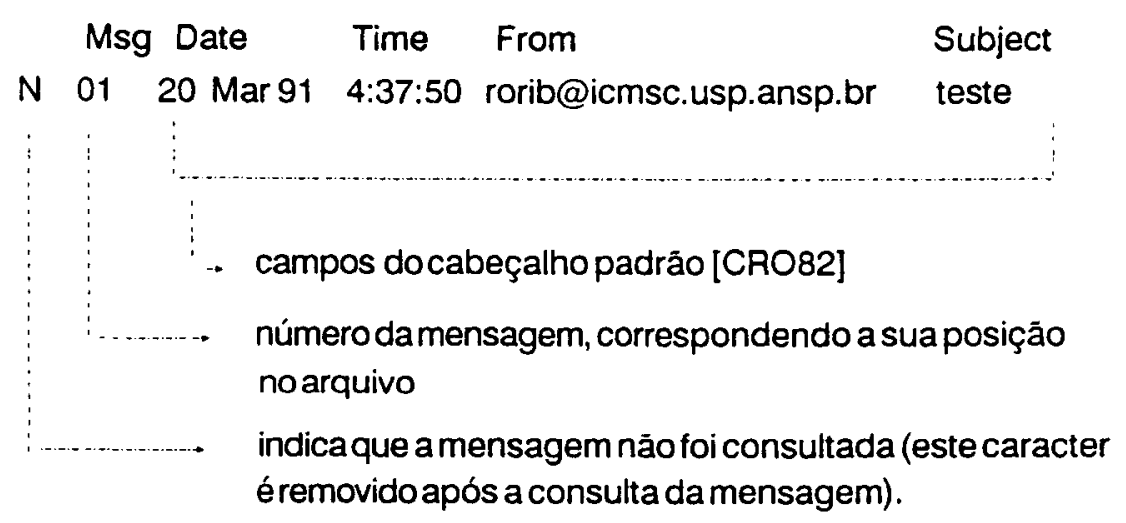

Figura 6.14: Linha de cabeçalho.

Considerações sobre a tela de apresentação:

- na parte superior da tela é identificado o nome do sistema, o ambiente utilizado e o nome do usuário;

- a parte inferior da tela é utilizada para esperar a escolha de uma primitiva, apresentar mensagens de erros e requisições de confirmação para a execução de uma primitiva; 
- a seleçào de uma mensagem é efetuada pelo posicionamento da seta apresentada no lado esquerdo da tela:

- um conjunto de primitivas é apresentado na parte inferior da tela. Lima primitiva é executada quando for pressionada a tecla correspondente a letra em destaque no nome da primitiva:

- na execuçào das primitivas "Delete", "Move" e "View". a tela de apresentação é atualizada para a nova situaçào:

- ao executar as primitivas, pode-se obter algumas explicaçòes sobre elas através da tecla Fl on cancelar sua execuçào através da tecla ESC;

- pode-se cmiar uma mensagem a vários destinatários. fornecendo-se os endereços dos destinatários separados por espaços:

- mensagens clestinadas aos usuários do ambiente LASD ou do sistema SunOS podem ser cndcreçadas pelo nome do destinatário. entretanto. mensagens destinadas a usuários de outros sistemas devem conter o endereço completo. por exemplo:

\section{destinatário@domínio1.domínio2 ... domínion.}

A figura 6.15 mostra a tela de gerência do sistema, disponivel somente aos "superusuários" nas estaçòes clientes.

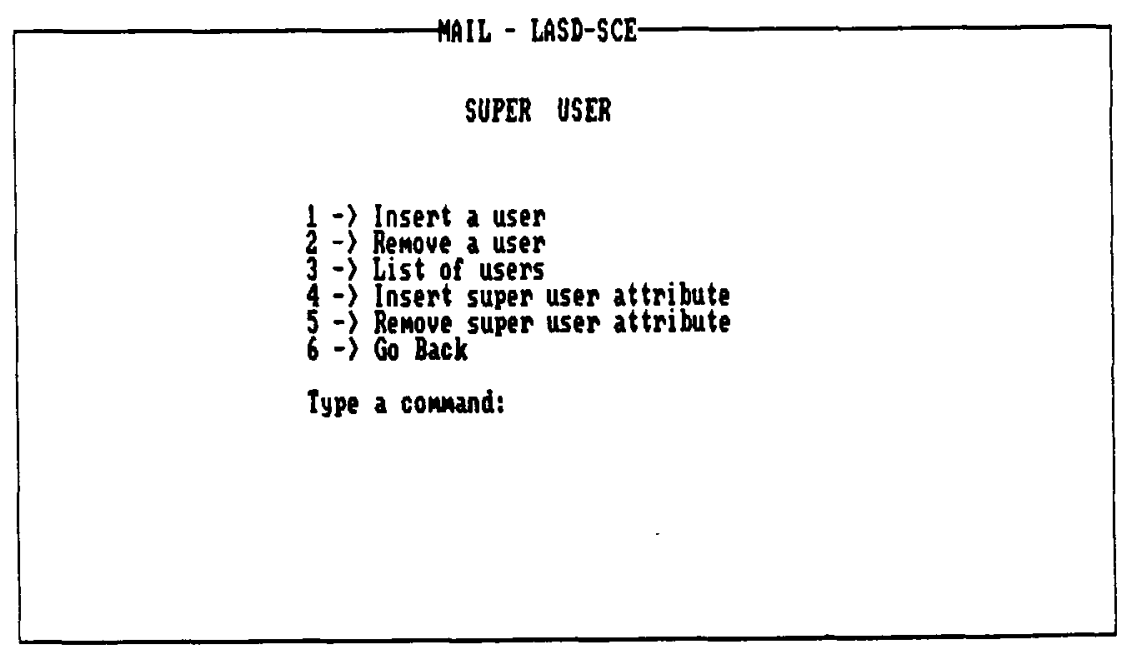

Figura 6.15: Tela para gerenciar o sistema.

Consideraçǒes sobre algumas primitivas:

$D=$ Delete: requisita uma confirmação para remover a mensagem ("Delete $Y / N$ ?"). No caso de confirmação, a tela de apresentação é atualizada. 
R=Reply: prenche o campo "To:" da mensagem com o endereso do remetente da mensagem sclecionada. sendo requisitado o assunto da mensagem. O usuário pode modificar o endereso on enviar a mensagem para mais do unn destinatário. É utilizado o editor de texto Virton para a composiçào da mensagem pelo usuário.

V=View: $\therefore$ utilizado um editor (LIST) para fornecer as funçòes de tela: PgUp, PgDn. e as setas para cima e para baixo. Se a linha de cabeçalho da mensagem apresentar o caracter "..". ute c removido. A primitiva "View" cfetua um "cache" na estação cliente. o qual permite a consulta da mensagem quantas vezes o usuário desejar, sem que um novo envio da mensagem pelo servidor seja necessário. O "cache" é removido quando o usuário responder negativamente à confirmaçào da consulta ("Do you want to consult this message again $\% / \stackrel{\circ}{*}$ ?.

$\mathrm{C}=\mathrm{Copy}$ : irepuisitado o nome do arquivo para copiar a mensagem, podendo fornecer um caminho comuleto.

$\mathrm{O}=\mathrm{Old}$ e $\mathrm{N}=$ New: é atualizada a parte superior da tela de apresentaçào, indicando a mudança de ambiente.

E=Exit: mesmo se o servidor nào responder à primitiva. o sistema é desativado na estaçào cliente (o servidor pode estar efetuando a comunicaçào com o sistema SunOS e o cliente nào deve ficar esperando muito tempo para desativar o sisterna).

$\mathrm{S}=$ Send: í (sào) requisitado(s) o(s) nome(s) do(s) destinatário(s) e o assunto da mensagem. É utilizado o editor de texto Norton para a composiçào da mensagem pelo usuário.

F=Forward: é requisitado o nome do destinatário.

$\mathrm{P}=$ Print: se uma impressora nào estiver disponível na estaçào, uma mensagem é enviada ao cliente e a primitiva é abortada.

$\mathbf{A}=\mathbf{p A s s w o r d}$ : sào requisitadas a senha anterior e duas vezes a senha nova.

U=sUper: apenas um "super-usuário" tem autorizaçào para executar essa primitiva. Nas primitivas: "Insere a user", "Remove a user", "Insere super user attribute" e "Remove super user attribute", é requisitado o nome do usuário. O sistema sempre requer a existência de pelo menos um "super-usuário". Para a primitiva "List of users" é utilizada a primitiva "View".

\subsection{Considerações finais}

A "extensão do mecanismo de RPC, implementando funções básicas para a transferência de arquivos, amplia as possibilidades de utilizaçăo desse mecanismo, que vem sendo utilizado em várias pesquisas do Laboratório de Sistemas Digitais do ICMSC.

O sistema servidor de correio eletrônico atende ao modelo MOTIS. O módulo cliente atua como UA, fornecendo uma interface amigável. O módulo servidor atua como MTA, 
pois possibilita a trausferência das mensagens dos usuários do ambiente LASD para o sistema SunOS. yur conseqüentemente atua como um .MTA.

O projeto foi lesenvolvido de forma a obter uma grande transparência para o usuário quanto a localizaçio do servidor. A instalaçào do software servidor é feita com grande facilidade e a inst alaçio do software cliente se resume na transferência do código à máquina cliente e na alteraçào do arquiro ESTCONF.FIG, pois cada estaçào deve abrir uma sessão diferente no servidor. 


\section{Capítulo 7}

\section{Conclusões}

Este capitulo conclue a dissertaçào revisando os tópicos fundamentais abordados, destacando as contribuiçòes alcançadas. apresentando as conclusòes finais e listando sugestões para a continuidade deste trabalho.

\subsection{Considerações iniciais}

Os sistemas computacionais distribuídos baseados em redes locais tornaram-se uma ferramenta poderosa. voltada ao incremento do trabalho cooperativo e facilitando o intercâmbio de informaçòes, principalmente dentro da comunidade científica mundial. As grandes redes de computadores, tal como a Internet, em expansào constante, permitem o intercâmbio de mensagens praticamente com o mundo todo. Nesse contexto, um mecanismo que forneça o serviço de correio eletrônico através de um sistema servidor que possibilita o envio e o recebimento de mensagens, mostra-se certamente de grande utilidade.

\subsection{Crítica bibliográfica}

\section{Sistemas Computacionais Distribuídos.}

A bibliografia sobre sistemas distribuídos é extremamente vasta e diversificada. Não há consenso entre os pesquisadores da área sobre uma conceituação única que defina o que é um sistema computacional distribuído. Contudo, é destacada à conceituação proposta por Andrew S. Tanenbaum e Robbert Van Renesse [TAN85] onde o ponto básico é a transparência. isto é, um usuário não precisa estar ciente do uso de múltiplos computadores. Mullender (discípulo de Tanenbaum) em [MUL89] também acrescenta aspectos de tolerância a falhas.

Os principais modelos arquiteturais estação de trabalho/servidor, banco de processadores e minicomputadores são discutidos pormenorizadamente por Tanenbaum em 
[TAN85]. Coulouris em seu livro [COLSS]. acrescenta duas combinaçòes desses modelos, introduzindo os modelos integrado e híbrido. O paradigma cliente/servidor é adotado via de regra e o mecanismo de comminicaçà $\mathrm{RPC}$ é apresentado como uma maneira para a comunicação entre processos nesse paradigma [COU88, MUL89. TAN89]. A implementaçào do mecanismo RP(' deve ser amparada por técnicas para tratamento (ou prevenção) da ocorrência de talhas [BIR85. COC88. SCH89. SHR82. TAN89].

Em geral. os servidores sào pouco discutidos pelos autores, exceção feita ao servidor de arquivos, que o destacado em diversos trabalhos como sendo o mais importante dos servidores. Servidores de correio eletrônico aparecem em alguns trabalhos sendo apontado como fundamental por Hilal em [HILsS].

Com relaçào ao meio de comunicaçào utilizado em sistemas distribuídos. as redes locais sào apontadas (omo uma das alternativas, pois apresentam alta velocidade e baixa taxa de erro a um custo relativamente baixo. Há um consenso na bibliografia sobre as técnicas de controle de accesso ao meio e as topologias utilizadas em redes locais.

\section{Protocolos de comunicação.}

Vários autores apresentam os protocolos de comunicaçào como sendo padròes, especificando como os dados devem ser representados para a transmissào de uma máquina a outra.

O modelo de referência ISO/OSI é um padrão que tem como finalidade fornecer uma base comum para a coordenaçào de novos projetos visando a interconexào de redes. Umas das diferenças entre o modelo de referência ISO/OSI e o modelo do conjunto de protocolos TPC/IP, é o número e a divisão de tarefas das camadas. Tanenbaum [TAN85] sugere que o número de camadas do modelo ISO/OSI seja reduzido para a utilização em redes locais, com a finalidade de se diminuir os custos, aumentar a velocidade de transmissão e melhorar o desempenho do sistema.

O conjunto de protocolos TCP/IP tem tido grande utilização e oferece um ambiente considerado maduro e estável [GET92]. Alguns dos equipamentos modernos de computação que estào sendo adquiridos por pesquisadores no país săo estações de trabalho que já vêm com interfaces Ethernet/IEEE 802.3, e geralmente são usadas em redes locais que empregam o conjunto de protocolos TCP/IP. Dessa forma, o conjunto de protocolos TCP/IP vem praticamente de "graça", permitindo que uma única instituição tenha instalada várias redes desse tipo, interligadas através de linhas seriais, pontes ou roteadores, formando assim uma inter-rede interna. A montagem dessa inter-rede é tecnicamente "fácil" quando todas as redes interligadas utilizam o conjunto de protocolos TCP/IP.

\section{Correio eletrônico.}

O correio eletrônico é um dos serviços de redes de computadores mais discutidos na bibliografia. Tanenbaum, em [TAN89], destaca a importância do serviço de correio eletrônico para a comunicação de pesquisadores espalhados pelo mundo inteiro. Apesar 
de algumas companhias fornecerem o serviço de correio eletrônico de forma centralizada, a grande utilizaçào desse serviço é feita de forma distribuida. visando principalmente o alcance do maior número de usuários. Em 1987, o Brasil iniciou seus esforços para obter ligações com as grandes redes internacionais objetivando dotar a comunidade científica do país com serviços de rede de computadores de bom nivel e alcance nacional/internacional - com o intuito de fornecer. entre outros. o serviço de correio eletrônico [GET92. MOR92].

A série de recomendaçòes $\mathrm{X} 400$ do CCITT é apontada como a base para o sistema MOTIS da ISO que concentra-se em todas as fases do serviço de correio eletrônico, ou seja, da criação da mensagem à entrega ao destinatário final.

O DNS é apresentado em diversos artigos como um sistema para mapear os nomes las máquinas e usuários em enderesos IP. Douglas E. Comer [COM191] destaca o esquema hierárquico de nomeaçào por domínios do DNS como um modo eficiente de nomeação para redirecionar as mensagens aos destinatários finais ou a "gateways" intermediários.

\subsection{Contribuições deste trabalho}

A seguir são apresentadas as contribuiçòes alcançadas com o desenvolvimento deste trabalho:

- implementação de um sistema aberto no ambiente computacional distribuído do LASD, que permite a extensào da utilizaçăo do serviço de correio eletrônico a outros ambientes apoiando-se no esquema do serviço de correio eletrônico existente no ambiente SunOS:

- viabilizaçào do uso da plataforma PC/DOS na ligação entre o ambiente SunOS a outros ambientes utilizando tecnologia Ethernet;

- "expansão" de um mecanismo de RPC proposto em outro trabalho [TRI91], removendo restriçōes existentes;

- a conceituação incluída neste trabalho representa uma resenha bibliografica compilada a partir de um número elevado de artigos que constitue certamente uma contribuição para aqueles em busca de informações nessa área.

\subsection{Conclusões}

As conclusões finais săo apresentadas a seguir:

- este trabalho demonstra a viabilidade de fornecer um serviço de corrreio eletrônico em um ambiente computacional distribuído, através da implementação de um sistema servidor dedicado. A idéia utilizada no servidor de correio eletrônico pode ser empregada em outros sistemas distribuídos, permitindo interligar um sistema 
que nào possua um serviço de correio eletrônico de alcance internacional (e até local) a outro que possibilite viabilizar tal serviço de uma forma eficiente:

- a interface conl o usuário mostrou-se um ponto importante no desenvolvimento do sistema. pois é através dela que se "escondem" os detalhes de implementação e apresenta-se a transparència do serviço fornecido. A utilizaçào desse serviço nào se restringe a usuários familiarizados com a área. A maioria dos usuários nào querem se preocupar em como o sistema foi implementado, mas sim. em utilizar um sistema amigável e confiável:

- a maneira como o sistema foi implementado permite que cada grupo possa utilizar um servidor particular, distribuindo melhor o fluxo das mensagens. Para cada servidor dece existir um esquema de alias distinto no sistema SunOS.

\subsection{Trabalhos futuros}

A seguir sào listadas sugestòes para a continuidade deste trabalho:

- instalar o software servidor de correio eletrônico em outras plataformas. Na versão inicial do sistema foi utilizado o sistema operacional DOS. que não oferece proteção sobre os arquivos. Uma opçào seria a utilização do servidor Lan-manager, que opera em um ambiente OS. Com relaçào a interface com o usuário seria de grande interesse adaptar a interface para a utilização de ambiente gráfico com inclusào do uso de "mouse" e "icones". tornando-a mais amigável;

- ampliar o número de primitivas disponíveis aos usuários, tais como:

- resposta automática: o usuário formula uma mensagem padrão, que seria enviada aos remetentes das mensagens recebidas;

- listas de distribuição: grupos de usuários com interesse comum seriam agrupados em listas, e uma mensagem endereçada a lista seria enviada a todo o grupo:

- utilização de alias: permitindo aos usuários enviar suas correspondências através dos alias ao invés de fornecer o endereço dos destinatários. Os alias seriam substituidos pelos endereços correspondentes antes do envio da mensagem para o sistema SunOS;

- "bulletin board": uma base de dados compartilhada entre os usuários do sistema, podendo ser dividida em seções, tais como, futebol, política, pós-graduação, etc. O usuário poderia enviar mensagens para as seções que desejasse e ler as mensagens das seções que lhe interesasse (ou que lhe fossem permitidas);

- "help": um arquivo de auxilio contendo algumas explicações gerais do sistema;

- inclusão de mensagens na composição de um nova mensagem;

- possibilitar a execução de funções do sistema operacional; 
- pesquisar cntre as funçes disponíveis no sistema SunOS um modo de executar o programa "lamail" nesse sistema sempre que o arquivo "entrada" fosse transferido;

- elaborar una nova versajo do sistema utilizando o protocolo FTP para efetuar a transferência de arquivos entre a estação servidor de correio eletrônico e as estações clientes:

- atribuir a um super-usuário a funçào de "postmaster" do sistema, ou seja, todas as mensagens destinadas ao subdomínio local que nào podem ser armazenadas na caixa postal lo destinatário. sào armazenadas na caixa postal do "postmaster" do sistema. 


\section{Apêndice A}

\section{Glossário}

cabo coaxial - meio de transmissào que apresenta um melhor desempenho e alcança distâncias maiores que o par trançado. permitindo um número maior de dispositivos conectados.

comutação por circuito - estabelece um caminho entre as estaçòes origem e destino, existindo assim um caminho dedicado para troca de dados. Quando a troca de dados se encerra. a conexào é desfeita.

comutação por pacote - a mensagem é dividida em pacotes que săo enviados de uma estação a outra até chegar á estação destino. Cada estação armazena o pacote, verifica se houve algum erro de transmissào, analisa o endereço destino e retransmite o pacote. Na estaçào destino a mensagem deverá ser remontada.

estação - designa um computador (PC, mini, "mainframe" e outros) conectado a um determinado ponto do sistema.

estação de trabalho - qualquer máquina com inteligência conectada à rede. Pode ser desde $\mathrm{PC}$ 's a estaçào especifica, com capacidade gráfica, processamento científico, etc.

fibra óptica - meio de transmissão que apresenta um desempenho muito superior ao cabo coaxial. Tem baixa suscetibilidade a ruídos possuindo um custo elevado.

hospedeiro - é uma estação que possue recursos próprios (tais como, disco e caixas postais dos usuários), sendo um ponto de ligação entre as estações conectadas a ele e as redes a que ele está conectado.

par trançado - meio de transmissão mais comum, usual para baixas velocidades e distâncias de poucos quilômetros. Permite conexão de poucos dispositivos sendo apropriado para transmissão de sinais digitais e analógicos. É sensivel a ruídos e interferências, e apresenta um custo baixo.

padrão FDDI - O protocolo FDDI foi desenvolvido pela ANSI nos EUA, sendo responsável pela sua padronização o comitê ASC (Accredited Standards Committee) X3T9. As redes FDDI operam em taxa de transmissão de $100 \mathrm{Mbps}$ com fibra óptica 
( esta bascido na lopologia de anel. com a passagem dr permissào como técnica de controle de acesso ao meio. Dois tipos de conexào estào previstas no padrào: classe A. a estaçio liga-se cliretamente ao anel e classe B. a estaçào liga-se ao anel atravês de un concentrador. A arquitetura FDDI especifica até a primeira subcamada do nivel de enlace (sub-camada $\mathrm{HAC}$ ). aceitando como sub-camada superior o protocolo l.LC' padrào IEEE s02.2. C'ada nó FDDI é composto das sub-camadas PHY (PHYsical layer protocol). P.ID (Physical layer Medium Dependent), MAC (Media Access Control) e S.MT (Station Managemen T). Sào especificados basicamente dois lipos de tráfego. O tráfego síncrono oferece banda garantida e tempo de acesso máximo para transmissào. porlendo ser usado em aplicaçòes em tempo real. O trálego assíncrono pode ser utilizado para serviços que precisem ter acesso ao canal de comunicaça com características de banda e acesso menos restritivas. Visando incorporat caracteristicas de redes metropolitanas (MAN). foi realizada uma otimizaçio no padrào FDDI para implementaçào do serviço de comutaçào por circuitos - FDI)I II [ROS 90 . TANS9].

memória "cache" - ¿uma memória de acesso muito rápido. que contém parte dos dados la memória principal (geralmente os que sào usados com maior frequêencia). A memória "cache" aumenta a relocidade de execuçào. pois o acesso a ela é mais rapido que à momória principal [C'OUS8. LEV90].

portadora - é uma frequêencia contínua com a capacidade de ser modulada, ou ser registrada com um segundo sinal e que contém uma informação. 


\section{Apêndice B}

\section{Lista de Siglas}

ANSP - Academic Network at São Paulo.

ANSI - American National Standards Institute.

BITNET - Because It's Time NETwork.

CCITT - Comité Consultatif Internacional de Télégraphique et Téléphonique.

CRC - Cyclic Redundancy Code.

CSMA - Carrier Sense Multiple Access.

CSMA/CD - Carrier Sense Multiple Access with Collision Detection.

DARPA - Defense Advanced Project Agency.

DEC - Data Communications Equipament.

DMSP - Distributed Mail System Protocol - protocolo da proposta de Lambert.

DNS - Domain Name System - mecanismo que implementa a hierarquia dos nomes das máquinas na arquitetura Internet.

Dod - Department of defese.

EARN - European Academic Research Network.

ECSNET - Electronic and Computing Science Network.

ESNET - Energy Sciences Network.

EMBRATEL - Empresa Brasileira de Telecomunicações.

FDDI - Fiber Distributed Data Interface.

FTP - File Transfer Protocol - protocolo da camada de aplicação da arquitetura Internet.

ICMP - Internet Control Message Protocol - protocolo da camada "internet" na arquitetura Internet. 
ICMSC - Instituto de C'iências Matemáticas de Sào Carlos.

IEEE - Institute of Electrical and Electronic Engineers.

IFIP - International Federation for Information Processing.

IFQSC - Instituto de Fisica e Química de São Carlos.

IP - Internet Protocol - protocolo da camada "internet" na arquitetura Internet.

IPC - InterProcess ('ommunication.

IPT - Instituto do Pesquisas Tecnológicas.

INPE - Instituto Nacional de Pesquisas Espaciais.

ISO - International Standards Organization.

ISO/OSI - International Standards Organization/Open Systems Interconnection.

LAN - Local Area Network.

LASD - Laboratório de Sistemas Digitais no ICNSC.

LLC - Logical Link Control - sub-camada a camada enlace de dados. utilizada no padrão IEEE 802 .

LNCC - Laboratário Nacional de Computação.

MAC - Medium Access Control - sub-camada da camada enlace de dados utilizada no padrão IEEE 802 .

MAN - Metropolitan Area Network.

MHS - Message Handling Systems - série de protocolos definidos pelo CCITT.

MME - Mail Manager Entity - entidade da proposta de YU.

MTA - Message Transfer Agent - entidade do sistema MOTIS.

MTE - Mail Transfer Entity - entidade da proposta de YU.

MOTIS - Message-Oriented Text Interchange Systems - sistema de padronização para correio eletrônico desenvolvido pela ISO.

MS - Message Store - utilizado pela entidade MTA no sistema MOTIS.

NCSA - National Center for Supercomputing Applications.

NFS - Network File System.

NIS - Network Information Service.

NSFNET - National Science Foundation Network. 
O/R - Originator/Recipient - formato dos endereços utilizado na série de recomendaçòes X400.

PKT - pacote de dados utilizado na interface com o mecanismo PaclieT Driver.

RFC - Request For Commments - artigos técnicos de dominio público da Internet.

RNP - Rede Nacional de Pacotes.

RPC - Remote Procedure Call.

SMTP - Simple Mail Transfer Protocol - protocolo da camada de aplicaçào na arquitetura Internet.

SPP - sistema Servidor de Processamento Paralelo - baseado em "transputers".

TABSERV - TABela de SERvidores - indexada pelo número de servidores, utilizada pelo processo cliente.

TCP - Transmission Control Protocol - protocolo da camada de transporte na arquitetura Internet.

TCP/IP - Transmission Control Protocol/Internet Protocol - mome do conjunto de protocolos da Internet.

TRICE - TRansportable Integrated Computing Environment - sistema distribuído de Southampton.

TSES - Tabela de SESsão - utilizada pelo processo servidor, indexada pelo número da sessão.

TU - Tabela de Usuários - indexada pelo número da sessão.

UDP - User Datagram Protocol - protocolo da camada de transporte na arquitetura Internet.

US-GOSIP - U. S. Government Open Systems Interconection Profile.

UA - User Agent - entidade do sistema MOTIS.

UCLA - Universidade da California - Los Angeles.

UFSCar - Universidade Federal de São Carlos.

UUCP - UNIX for UNIX CoPy.

WAN - Wide Area Network. 


\section{Bibliografia}

[ABB86] ABBOTT. G. F.. Office automation. IEEE Communications Magazine, v. 24. n. i. p. 6-i. juls: 1986.

[AL.MSi] ALMES. (i. T.: HOLMAN. C. L. Edmas: an object-oriented locally distributed mail system. IEEE Transactions on software Engineering. v. 13. n. 9. p. 1001-9, september, 1987 .

[A.MPS8a] AMPLI'S. INFORMÁTICA S.A. AMPLICARD AC 210/XT: manual de instalação, rersào x.1. Rio de Janeiro, Amplus Informática. 1988.

[AMPSSb] AMPLIS. INFORMÁTICA S.A. AMPLICARD AW DOS: manual do usuário, versão 1.2, Rio de Janeiro, Amplus Informática, 1988.

[BAL89] BAL, H. E.: STEINER, J. G.; TANENBAUM, A. S.. Programming languages for distributed computing systems. ACM Computing Surveys, v. 21, n. 3, p. 261-322, september, 1989.

[BIR84] BIRRELL. A. D.; NELSON, B. J.. Implementing Remote Procedure Calls. ACM Transactions on Computer Systems, v. 2, n. 1. p. 39-59, february, 1984.

[BIR85] BIRRELL. A. D.. Secure Communication Using Remote Procedure Calls. ACM Transactions on Computer Systems, v. 3 , n. 1. p. 1-4. february, 1985.

[CLA78] CLARK, D. D.; POGRAN, K.T.; REED, D. P.. An introduction to local area networks. Proceedings of the IEEE, v. 66, n. 11, p. 1497-517, november, 1978.

[CLA89] CLARCSON University, User Documentation for Packet Driver Collection, version 1.09 .

[COM91] COMER, D. E.. Internetworking with TCP/IP principles, protocols and architecture. $\quad$ New Jersey, Prentice-Hall, 1991.

[COU88] COULOURIS,G. F.; DOLLIMORE, J.. Distributed systems: concepts and design. Wokingham, Addison-Wesley, 1988.

[CRO82] CROCKER, D. H. et al. Standard for the format of Arpa Internet text messages. In: ARPANET Working Group Request for Comments, RFC 822, august, 1982.

[CUN84] CUNNINGHAM, I.. Electronic mail standards to get rubber-stamped and go worldwide. Data Communications, v. 13, n. 5, p. 159-68, may, 1984. 
[CUN85] CUNNINGHAM. I.: KERR. I.. New electronic mail standards. In: Stalling, W. - Tutorial: Computer communications: architectures. protocols, and standards. 2 ed. Washington. IEEE. 1987 . p. 394- $\tau$.

[DIGS8] DIGITAL. EQLIPAMENT CORPORATION - VMS general user's manual. New Hampshrire. Digital Eq. Corp., 1988.

[DIXS8] DIXON, R. C.: PITT. D. A.. Addressing, bridging and source routing. IEEE Vetwork Magazine. ․ 2. n. 1. p. 25-31, january. 1988.

[DVOS9] DVORAK.J. C.. AVIS. N..Duorak's guide to PC telecommunications. Berkeley, Mc Graw-Hill. 1989.

[ENSTS] ENSLOW. P. H.. What is a distributed data processing system?. IEEE Computer. v. 11. 1. 1. p. 13-21. january, 1978.

[FISS9] FISCHER. G.. Iuman-computer interaction software: lessons learned. challenges ahead. IEEE Softure. r. 6, n. 1, p. 44-52, january, 1989.

[FITS9] FTP Software In. PC/TCP Packet Driver Specification. version 1.09 US, FTP Software Inc. 1989.

[GET92] GETSCHKO. D.: STANTON, M. A.. A evoluçào de redes acadêmicas no pais. In: SIMPÓSIO BRASILEIRO DE REDES DE COMPUTADORES, 10, Recife. Anais. Recife. Editora Universitária - UFPE. p. 149-65. 1992.

[GIO86] GIOZZA, W. F. et al.. Redes locais de computadores: tecnologia e aplicações. São Paulo. Mc Graw-Hill. 1986.

[GIA89] GIANONE, C.: CRUZ, F.. C-Kermit user guide, for UNIX, VMS, and many other operating systems. Columbia University center for computing activities, New York, version $4 \mathrm{E}(072)$, february, 1989.

[GRA83] GRAFT, R.. Modeling an electronic mail network: a primer. Data Communications, v. 12, n. S, p. 163-7T, august, 1983.

[HIL88] HILAL, W. B.; YUEN, H.. Designing large electronic mail systems. In: Annual Conference on local computer networks, 13. 1988, p. 402-9.

[HIN83] HINDEN, R.; HAVERTY J.; SHELTZER, A.. The DARPA interconnecting heterogeneous computer networks with gateways. Computer, v. 16, n. 9, p. 38-48, september, 1983.

[HORS6] HORTON, M. R.. UUCP mail interchange format standard. In: ARPANET Working Group Request for Comments, RFC 976, february, 1986.

[HU86] HU, W.. Design and implementation of a gateway between two electronic mail systems. IEEE Communications Magazine, v. 24, n. 6, p. 18-23, june, 1986.

[HUF87] HUFFMAN, A. J.. E-mail - The "glue" to office automation. IEEE Network Magazine, v. 1, n. 4, p. 4-10, october, 1987. 
[HTTST] HUTCHISON. G.: DESMOND. (.. L.. Electronic data interchange. Vetwork Magazine . 1. 1. 11. 4. p. 16-20, october. 1987.

[JUEST] JUENEMAN. R. R.. Electronic document authentication. IEEE Network Magazine, v. 1, n. 2, p. 17-25, april. 1987.

[KAR91] KARN P.: IET user Reference Manual. NOS Version. june, 1991.

[KIR88] KIRNER. C'.. Sistemas Operacionais Dsitribuidos, aspectos gerais e análise de sua estrutura. Rio de Janeiro. Editora Campus. 1988.

[LAGS6] LAGES. N. A. C.: NOGUEIRA. J. M. S.. Introdução aos sistemas distribuídos. Campinas. Papirus/Inicamp. 1986.

[LA.MS8] LAMBERT. M.. Pcmail : A distributed mail system for personal computers. In: ARPANET Working Group Request for Comments. RFC 1056. june, 1985,

[LAN86] LANDWEBER. L. H. : JENNINGS. D. M.: FUCHS. I.. Research computer networks and their interconnection. IEEE Communications Magazine, v. 24, n. 6, p. j-16. june. 1986.

[LAR82] LARMOUTH. J.. C'ambridge Ring 82 protocol specifications. Computer Board and Reserch Councils. november, 1982.

[LEV90] LEVY, E.; SILBERSCHATZ, A.. Distributed file systems: concepts and exemples. ACM Computing Surveys, v. 22, n. 4, p. 321-74, december, 1990.

[LIC78] LINCKLIDER. J. C. R.. Applications of informations networks. Proceedings of IEEE, v. 66, n. 11. p. 1330-446, november, 1978.

[LIS90] LISKOV, B.; SHRIRA L.; WROCLAWSKI, J.. Efficient a-most-once messages based on synchronized clocks. ACM, p. 41-9, 1990.

[MAR91] MARCLS. A. et al. User-interface developments for the nineties. Computer, p.49-57, september, 1991 .

[MET76] METCALFE, R. M.; BOGGS, D. R.. Ethernet: distributed packet switching for local computer networks. Communications of the $A C M$, v. 19, n. 7, p. 395-403, july, 1976.

[MITS9] MITCHELL, C.. Multi-destination secure eletronic mail. The Computer Journal, v. 32, n. 1, p. 13-5, 1989.

[MOR92] MORGADO, E. M.. Avaliaçào da implantação da Bitnet nas Universidades estaduais paulistas. In: SIMPÓSIO BRASILEIRO DE REDES DE COMPUTADORES, 10, Recife. Anais. Recife, Editora Universitária - UFPE, p. 80-91, 1992.

[MOU86] MOURA, J. A. B. et al. Redes locais de computadores, protocolos de alto nível e avaliação de desempenho. São Paulo, Mc Graw-Hill, 1986.

[MUL89] MULLENDER, S. J. (ed). Distributed systems. New York, Addison-Wesley. 1989. 
[MYES9] MYERS. B.. Cser-interface tools: introduction and survey. IEEE Software, v. 6. n. 1. p. 1.)-2:3. january. 1989.

[NEW82] NEWELL. A.: SPROILL. R. F.. Computer networks: prospects for scientists. Science, v. 21ij. n. 12. p. 843-52. february, 1982.

[NCS91] NCSA Telnet for the IB.M PC rersion 2.3. University of Illinois at UrbanaChampaign, june. 1991.

[ORD91] ORDILLE. J. J.: MILLER. B. P.. Nomenclator descriptive query optimization for large X500 environments. ACM-Press Communications Archictectures 6' Protocols. p. 185-96. 1991.

[ORTS6] ORTO . E.: NASATIR. R.. Getting the most out of electronic mail. Data Communications. v. 15. n. T. p. $189-99$ june. 1986.

[PARS6] PARTIDGE. C.. Mail routing and domain system. In: ARPANET Working Group Request for Comments, RFC 9Tt, january, 1986.

[POS81] POSTEL. J.. Internet protocol. In: ARPANET Working Group Request for Comments, RFC 791, september. 1981.

[POS82] POSTEL. J.. Simple mail transfer protocol. In: ARPANET Working Group Request for Comments. RFC 821, august 1982.

[POS83] POSTEL, J; REYNOLDS, J.. Telnet protocol specification. In: ARPANET Working Group Request for Comments, RFC 854, may 1983.

[PRES87] PRESSMAN. R. S.. Software engineering - a practitioner's approach. New York, Mc Graw-Hil, 1987.

[QUA86] QUARTERMAN, J. S.; HOSKINS, J. C.. Notable computer networks. Communications of the ACM, v. 29, n. 10, p. 932-71, october, 1986.

[RAV89] RAVINDRAN. K.; CHANSON, S. T.. Failure Transparency in Remote Procedure Calls. IEEE Transactions on computers, v. 38, n. 8, p. 1173-87, august, 1989.

[RED83] REDELL, D. D.; WHITE J. E.. Interconnecting electronic mail systems. Computer, v. 16, n. 9. p. 55-63, september, 1983.

[ROS90] ROSS, F. E. et al.. FDDI - A Lan among MANs. Computer Communications Review, v. 20, n. 3, p. 16-31, july, 1990.

[SAN87] SANTOS, L. F. B. P.. Segurança de dados em correio eletrônico. In: CONGRESSO NACIONAL DE INFORMÁTICA, 20, São Paulo, 1987. Anais. São Paulo, SUCESU, 1987, v. 1, p. 339-41.

[SAN89] SANTANA, M. J.. An advanced flestore architecture for a multiple-LAN distributed computing system. University of Southampton U.K, Departament of eletronics and Computer Science, 1989. 
[SAN92] SANTIN. Y. M. J.: RIBEIRO. R.. Electronic-Mail Serrer in a Distributed Computing Enrironment In: XII International Conference of the chilean computer science society. Samiago do Chile. 1992.

[SCH89] SCHROEDER. M. D.: BLRROWS. M.. Performance of firefly RPC. ACM, p. $83-90$. 19:?.

[STE90] STEVLiS. IV. LNIX network programming. Englewood Clifs, Prentice-Hall, 1990.

[SHO7S] SHO('II. I. F.. Inter-network naming, adressing, and routing. In: Lam, S. S.

Tutorial: Principes of Communication and the networking protocols. Los Angeles, 1984. p. 33.9-96.

[SH0S2] SHOC'H. I. I: : D.AL.AL. Y. K.: REDELL. D. D.. Erolutions of the Ethernet local computer network. IEEE Computer. v. 15. n. S. p. 10-27. august. 1982.

[SHRS2] SHRITISTAIA.S. K.; P.ANZIERI, F.. The design of a reliable remote procedure call mechanism. IEEE Transactions on computers. v. 31. n. T. p. 692-7, july, 1982.

[SIL92] SILVA. R. M.: Desenvolvimento do sistemas numa rede TCP/IP. São Carlos, ICMSC, 199.2.

[SIN91] SINGH:UL. M.: CASAVANT. T. L.. Distributed computing systems. Computer, p. 12-5. august. 1991.

[SOA 86] SOARES. F. G.. Redes locais. Rio de Janeiro. Campus. 1986.

[SOLST] SOLMA...J. I.. Design of a public electronic mail system.

IEEE Network Magazine. ․ 1. p. 16-20. october, 1987.

[SQU89] SQUILLANTE. M. S.: NOTKIN, D.. Integrating heterogeneous local mail systems. IEEE Softuare. . 6, n. 6, p. 59-67, november. 1989.

[STA84a] STALLINGS. W.. Local networks. ACM Computing Surveys, v. 16, n. 1, p. 3-41, march. 1984.

[STA84b] STANIOOVIC. J. A. ; A perspective on distributed computer systems. IEEE Transactions on Computer, v. 33, n. 12, p 1102-15, december 1984.

[STA92] STANTON, M. A.. A rede interna da PUC-RIO. In: SIMPÓSIO BRASILEIRO DE REDES DE COMPUTADORES, 10, Recife. Anais. Recife, Editora Universitária - UFPE, p. 93-105, 1992.

[SU82] SU, Z.; POSTEL, J.. The domain naming convention for Internet user applications. In: ARPANET Working Group Request for Comments, RFC 819, august 1982.

[SUN90] SUN MICROSYSTEMS, INC. SunOS User's guide: getting Started. California, SUN MICROSYSTEMS, INC 1990.

[SUN91a] SUN MICROSYSTEMS, INC. SPARC Desket reference guide. California, SUN MICROSYSTEMS, 1991. 
[SLN91b] SUN MICROSYSTEMS. INC. SPARC Sun system user's guide. C'alifornia, SUN MICROSYSTEMS. 1991.

[SVOS4] SVOBODOVA. L.. File servers for network-based distributed systems. Computing Surveys, v. 16. n. 4. p. 353-95. december, 1984.

[TAN85] TANENBAUM. A. S.: RENESSE, R. V.. Distributed operating systems. Computing Surveys, r. 17, n.4, p. 419-69, december, 1985.

[TAN90] TANENBALI. A. S. et al.. Experiences with the Amoeba distributed operating system. Communications of the ACM, v. 33, n. 12. p. 47-63, december, 1990.

[TAN89] TANENBAUM. A.S.. Computer Networks. 2 ed. Englewood Cliffs, Prentice Hall. 1989.

[TARS6] TAROLC'O. L. M. R.. Redes de computadores locais c de longa distância. São Paulo. Mc Graw-Hill. 1986.

[TAR92] TAROUC'O. L. M. R.. Integraçào de redes acadèmicas: aplicaçòes e gereciamento cooperantes. In: SIMPÓSIO BRASILEIRO DE REDES DE COMPUTADORES. 10, Recife. Anais. Recife, Editora Universitária- UFPE, p. 361-74, 1992.

[TOMS0] TOMANEK, G.. Implementing electronic mail in a telephone system: more than just talk: In: Thurber, K. J.; Freeman, H. A. - Tutorial: Local Computer Networks. 2 ed. New York, IEEE, 1981. p. 367-i1.

[TOM85] TOMLINSON. G. M. et al. The PULSE distributed file system. Software Practice and Experience, v. 15, n.11, p. 1087-101, november. 1985.

[TRA91] TRAVEISO, Monica M. R. G.. Implementação de correio eletrônico em ambientes heterogêneos. Sào Carlos, ICMSC, 1991.

[TRI91] TRINDADE, O. J.. Servidor de processamento paralelo baseado em banco de transputers. São Carlos, IFQSC, 1991.

[VAU90] VAUGHAN-NICHOLS, S. J.. X400: stardardizing e-mail. Byte, v. 15, n. 13, p. 341-4, december, 1990.

[YU79] YU, L.. The anatomy of a distributed eletronic mail network. Data Communications, v. 8, p. 104- $7,1979$.

[WIL87] WILBUR, S.; BACARISSE B.. Building distributed systems with remote procedure call. Software Engineering Journal, p. 148-59, september, 1987. 